
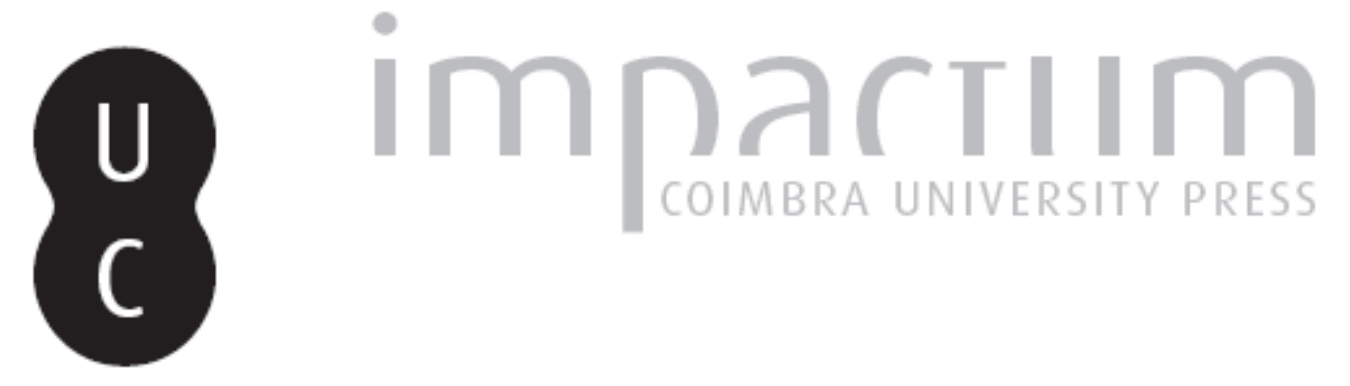

\title{
A organização social dos povos do Noroeste e Norte da Península lbérica nas épocas pré-romana e romana
}

Autor(es): $\quad$ Alarcão, Jorge de

Publicado por: Faculdade de Letras da Universidade de Coimbra

URL persistente:

URI:http://hdl.handle.net/10316.2/37683

DOI:

DOI:http://dx.doi.org/10.14195/1647-8657_42_1

Accessed : $\quad$ 26-Apr-2023 13:40:09

A navegação consulta e descarregamento dos títulos inseridos nas Bibliotecas Digitais UC Digitalis, UC Pombalina e UC Impactum, pressupõem a aceitação plena e sem reservas dos Termos e Condições de Uso destas Bibliotecas Digitais, disponíveis em https://digitalis.uc.pt/pt-pt/termos.

Conforme exposto nos referidos Termos e Condições de Uso, o descarregamento de títulos de acesso restrito requer uma licença válida de autorização devendo o utilizador aceder ao(s) documento(s) a partir de um endereço de IP da instituição detentora da supramencionada licença.

Ao utilizador é apenas permitido o descarregamento para uso pessoal, pelo que o emprego do(s) título(s) descarregado(s) para outro fim, designadamente comercial, carece de autorização do respetivo autor ou editor da obra.

Na medida em que todas as obras da UC Digitalis se encontram protegidas pelo Código do Direito de Autor e Direitos Conexos e demais legislação aplicável, toda a cópia, parcial ou total, deste documento, nos casos em que é legalmente admitida, deverá conter ou fazer-se acompanhar por este aviso.

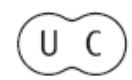


CONIMBRIGA

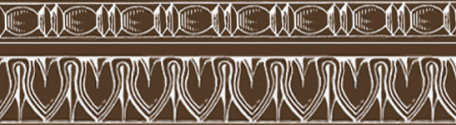

NSTITUTO DE ARQUEOLOGI

I

VOLUME XLII - 2003

A C U L D

UNIVERSIDADE DE COIMBR 
JoRGE DE AlARCÃo

Professor da Faculdade de Letras de Coimbra

\section{A ORGANIZAÇÃO SOCIAL DOS POVOS DO NOROESTE E NORTE DA PENÍNSULA IBÉRICA NAS ÉPOCAS PRÉ-ROMANA E ROMANA}

“Conimbriga" XLII (2003) p. 5-115

RESUmo: As fontes literárias antigas e, sobretudo, as epigráficas têm sido a base para a reconstituição da organização social dos povos do Norte e Noroeste da Península Ibérica nas épocas pré-romana e romana. Outros dados, como a dimensão das unidades habitacionais, a dimensão dos povoados e a sua distribuição espacial devem, porém, ser igualmente considerados.

Os termos gens, gentilitas, cognatio e os genitivos do plural em -um e -orum não designam, provavelmente, em todos os casos, o mesmo tipo de grupo familiar. É possível que tais nomes se tenham aplicado, no Norte e Noroeste, a famílias alargadas de mais elevado status. Apresentam-se hipóteses para explicar o que se afigura singular e difícil de entender: a razão por que tão poucas inscrições funerárias incluem os dedicados numa "unidade organizativa".

SUMMARY: The historical reconstruction of the social organization of Northern and Northwestern Hispania during the Late Iron Age and the Roman period have been based on some references in Classical writers like Strabo and on funerary inscriptions. Other forms of evidence should be considered, like the dimension of the houses (or domestic units), the dimension of the settlements and their spatial distribution.

The names gens, gentilitas, cognatio and the Latin names in -um or -orum based on personal names may have been given to different 
types of family groups. At least in some cases, these groups may have been those of higher status within their communities.

Suggestions are presented here to explain why so few funerary inscriptions include the honoured deceased in a gens, gentilitas or in a social unit referred to by a name in -um or -orum. 


\section{A ORGANIZAÇÃO SOCIAL DOS POVOS DO NOROESTE E NORTE DA PENÍNSULA IBÉRICA NAS ÉPOCAS PRÉ-ROMANA E ROMANA}

\section{Introdução}

As informações de autores gregos e latinos sobre as estruturas familiares e a organização sociopolítica dos povos do Noroeste e Norte da Península Ibérica, na época pré-romana, são escassas e equívocas e devem sempre ser lidas com prudência, atendendo a possíveis "etnocentrismos" desses autores. Isto não significa que tais notícias não sejam úteis e merecedoras de consideração. A hermenêutica desses textos é um processo que terá de ser extremamente prudente, mas não podemos desconfiar deles ou descreditá-los sem ponderosos argumentos.

Sem pretendermos coligir todas essas informações, aludiremos a algumas poucas como exemplos de notícias cuja interpretação não é óbvia. Assim, a que é que correspondem, exactamente, as gentes dos Ástures citadas por Floro, II, 33, 52-60, gentes que, por determinação de Augusto, deviam reunir o seu concilium no local onde os Romanos tinham um acampamento militar (talvez o lugar da futura Asturica Augusta)? E esse concilium foi uma criação de Augusto, ou, como sugere Ma․ Cruz González Rodríguez (1997:59), já existiria antes da submissão dos Ástures pelos Romanos? Ou o que era a syngéneia referida por Estrabão III, 3, 7? Ou que regime de propriedade e transmissão hereditária de bens existia entre os Cântabros, regime implícito no facto, registado pelo mesmo geógrafo, III, 4, 18, de serem as filhas a herdarem e a escolherem mulheres aos seus irmãos? Esta última referência de Estrabão (que, a propósito, fala de uma "espécie de ginecocracia") não deve considerar-se pertinente apenas para o conhecimento do direito de herança, das regras de filiação, das normas observadas na 
escolha dos cônjuges ou das regras de residência (virilocal ou uxorical), pois tudo isto se relaciona com a configuração das unidades familiares (ou de parentela).

Estas e outras referências dos autores gregos e latinos deixam-nos muitas dúvidas sobre as formas e as funções das "unidades organizativas" indígenas. Se o problema das funções e, sobretudo, de eventuais funções políticas e económicas dessas unidades é um dos mais obscuros no amplo debate sobre a organização social do Noroeste e Norte peninsulares, o problema das formas não pode considerar-se resolvido de maneira satisfatória: essas unidades eram famílias? linhagens? clãs? ou eram outra qualquer coisa?

Abundante, ainda que toda ela posterior à conquista da região pelos Romanos, a epigrafia permite identificar diversos tipos de unidades, que uns autores preferem chamar "unidades organizativas" (GonZÁlez RodríGueZ, 1986 e 1994; SAlinas DE FríAs, 1994), outros, "grupos de parentes" (BELTRÁN, 1994), outros, "organizações suprafamiliares" (ALBERTOS FIRMAT, 1975) e outros ainda, "gentilidades" (Gomes-Pantoja, 1996). Pela nossa parte, adoptaremos aqui o termo "unidades organizativas", sem tentarmos sequer inventar outro. Talvez um termo novo venha a ser possível e justificável quando entendermos devidamente a(s) forma(s) e as funções de tais unidades.

Temos notícia de castella, gentes, gentilitates e cognationes. Para além destes termos latinos epigraficamente atestados, nas fórmulas onomásticas, isto é, na identificação dos dedicados das inscrições funerárias (e, por vezes, também dos dedicantes), há nomina em genitivos do plural terminados em -un, -um, -on, -om ou -orum.

Se os castella não correspondem a grupos de parentesco (e não terá havido nunca semelhante correspondência?), serão grupos de parentesco as "unidades organizativas" designadas pelos nomes de gens, gentilitas e cognatio e pelos genitivos do plural? E os diversos termos corresponderão a diversos tipos de "unidades organizativas", ou são nomes alternativos para um mesmo e único tipo de unidade?

Às dificuldades que encontramos na definição das unidades sociais, das suas formas e das suas funções, acrescem as dúvidas sobre se se trata, de facto, de unidades já próprias dos povos pré-romanos ou de unidades configuradas pelos Romanos. A hipótese de que estas unidades têm origem romana (timidamente assumida por GONZÁLEZ RodríGUEZ, 1997: 75-76 e claramente sustentada por SASTRE PRATS, 2001: 164 s., designadamente 185), parece-nos menos razoável que a 
oposta. Mas na hipótese, que parece a mais credível, de unidades com origem pré-romana, que transformações se terão operado nelas e nas suas funções? As unidades sociais pré-romanas ter-se-ão mantido, mas terão perdido as suas funções (ou algumas das suas funções) estruturantes da sociedade, agora que o mundo tinha novos quadros político-administrativos, novas formas de propriedade e novas relações sociais de produção, formas de fiscalidade até então desconhecidas e maiores desigualdades sociais? Não podemos esquecer que a sociedade é uma realidade sempre em processo de estruturação, desestruturação, reestruturação e que o novo ou o diferente sai do antigo. Talvez as sociedades pré-romanas tenham evoluído, em tempo lento ou vagaroso e o ritmo de evolução se tenha tornado rápido a partir dos primeiros contactos com os Romanos.

Os problemas relativos à organização social dos povos do Noroeste e Norte peninsulares na época pré-romana e à sobrevivência, depois da conquista, com maiores ou menores reconfigurações, dessas formas indígenas de organização têm constituído, desde a década de 1980, temas de muitas discussões e de importantes trabalhos de investigação. Se o progresso tem sido inequívoco, em parte determinado por novas descobertas epigráficas e pela utilíssima reunião, por $\mathbf{M}^{\mathrm{a}}$. Cruz González Rodríguez (1986), de todas as inscrições então conhecidas com menção de gentes, gentilitates e genitivos do plural, não se chegou ainda a um consenso quanto à natureza e funções dos grupos ou unidades que tais nomes designam. Assim, para Francisco Beltrán (1994: 90-91 e 95-96), os termos gens, gentilitas e cognatio, bem como os genitivos do plural, reportam-se todos ao mesmo tipo de unidade, que o autor considera "grupos parentales", embora diminua o papel do parentesco como elemento estruturante da sociedade hispano-romana. Para Mª . Cruz González Rodríguez (1986; 1994; 1998), as "unidades organizativas" designadas por genitivos do plural e as cognationes são equivalentes, mas as gentilitates são unidades de outro tipo, com vinculação a um território, "situadas a meio caminho entre o âmbito social e o político" (1998: 343). Para F. J. Lomas (1990), os termos gens e gentilitas e os genitivos do plural designam um mesmo tipo de unidade, que o autor chama de segunda ordem. As unidades de primeira ordem seriam as famílias e as de terceira ordem, os populi. Por outro lado, Inés Sastre Prats $(1998 ; 2001)$ vem defendendo uma tese que, não parecendo convincente, não pode deixar de merecer atenção. Para esta autora, numa perspectiva historiográfica marxista, as "unidades organizativas" 
seriam, essencialmente, grupos de dependência, funcionais do ponto de vista das relações sociais de produção: “...las unidades organizativas no se fundamentan en el parentesco, sino en la dependencia". Mas a autora não deixa de admitir que "puedan estar baseadas en la manipulación ideológica del parentesco fictício en la representación de las relaciones sociales" (1998: 52).

A discussão sobre o sentido dos termos gens, gentilitas e cognatio e dos nomes em genitivo do plural parece ter desembocado apenas num único consenso: a negação da tese dita "gentilícia", adaptada de Morgan e prevalecente até à década de 1980. Segundo essa tese (resumida em GoNZÁLEZ RodRíGUEZ, 1986: 78-86 ou BELTRÁN, 1994: 73-77), as famílias integrar-se-iam em linhagens; estas, em clãs; os clãs, em tribos; e as tribos, em confederações tribais. Os Astures seriam uma confederação tribal; os Zoelae, uma tribo; as gentilitates Desoncorum e Tridiavorum do "pacto de Astorga" CIL II 2633 seriam clãs. A teoria "gentilícia", porém, envolvia, para além da ideia do papel estruturante do parentesco na organização sociopolítica, outras teses não menos importantes, como a ausência de desigualdades sociais e o comunitarismo dos meios de produção. Na defesa da tese do comunitarismo, era frequentemente invocado o testemunho de Diodoro, V, 34, 3 sobre os Vaccaei, que anualmente distribuíam por sortes os campos de semeadura, mas punham as colheitas em comum e depois as distribuíam segundo as necessidades de cada um (CARO BAROJA, 1976: 170. Sobre o assunto, vid. também SALINAS DE FRÍAS, 1989).

Talvez os conceitos de tribo e de clã (ou, em vez do conceito de tribo, o eventualmente mais actualizado de etnia ou grupo étnico, vid. BARTH, 1981: 198-227 e JONES, 1998) não devam, porém, ser apressadamente rejeitados (como fazem certos autores, v.g. SANTOS: 1994: 182) e possam manter-se operacionais na nossa tentativa de reconstituir a organização social ou sócio-política dos povos do Noroeste e Norte peninsulares na época pré-romana.

A linhagem "é um grupo de aparentados em que cada membro pode determinar a sua conexão genealógica com qualquer outro membro do mesmo grupo por descender de um antepassado comum conhecido, enquanto num clã isso não é possível" (RADCLIFFE-Brown e FORDE, 1982: 58). Quanto ao clã, é um grupo de indivíduos (ou melhor, de famílias) que se auto-representam como aparentados, por se suporem descendentes de um antepassado comum. Mas este antepassado situa-se tão recuado no tempo que a população presente não pode reconstituir a árvore genealógica. 
Estas definições de linhagem e de clã são consensualmente aceites pela Antropologia Cultural, com a reserva, irrelevante para o nosso fim, de os autores americanos preferirem o termo clã por designar o grupo de descendência baseado na matrilinearidade e usarem gens para o grupo de descendência por linha masculina.

Quanto à tribo, se este conceito tem sido criticado, e se muito antropólogos têm sustentado a artificialidade de certas tribos das quais se fala, por se tratar de largos grupos criados ou configurados pela colonização europeia, e não correspondentes a unidades émicas, isto é, reconhecidas e "vividas" pelos próprios indígenas, a verdade é que mesmo sociedades sem estruturas claramente hierarquizadas têm ou podem ter consciência da sua identidade como um todo social e contraporem-se a outras unidades que, para as primeiras, são "os outros". Que a estas unidades se dê o nome de tribos ou etnias ou que para elas se utilize o nome latino de populus é também, para nós, aqui, irrelevante. De qualquer forma, chamaremos aos Zoelae, populus.

O que importa é admitir que, por pouco hierarquizadas que fossem as sociedades do Noroeste e do Norte peninsulares aquando da sua anexação pelos Romanos (e talvez as do Noroeste fossem mais hierarquizadas que as das Astúrias e Cantábria), havia certamente grupos que se auto-reconheciam em círculos progressivamente mais abrangentes de "nós": os "nós" de um castellum, opostos aos "outros" de outro castellum, e os "nós" destoutro, opostos aos do primeiro, poderiam reconhecer-se solidários no âmbito de um"nós" mais abrangente, que poderia eventualmente ser um clã ou, sem a intermediação de clãs, no seio de um populus.

Neste momento, não nos parece útil desenvolver este modelo de organização social, mas apenas manter, por precaução metodológica, a ideia de que pode ter havido, no Noroeste e Norte peninsulares, linhagens integradas em clãs e clãs integrados em etnias ou populi. Não se trata, por enquanto, de sustentar a existência de clãs, mas apenas de manter a hipótese de eles poderem ter existido. A esta precaução acrescentaremos uma "dúvida metódica": será que gentes, gentilitates, cognationes e genitivos do plural em -um designam um mesmo e único tipo de "unidade organizativa"? Indo mais longe: estes termos têm, em todos os lugares e contextos, o mesmo sentido? Uma unidade de Cântabros Vadinienses designada por um genitivo do plural em -um é idêntica a uma unidade dos Vetões designada também por um genitivo do plural em -um? 
O presente trabalho não tem por intenção apresentar um modelo novo de reconstituição histórica do que terão sido as "unidades organizativas" indígenas no Noroeste e Norte peninsulares.

"Na linguagem científica, um modelo é essencialmente um procedimento heurístico que serve para demolir uma interpretação inadequada e abrir caminho a uma interpretação nova e mais adequada" (RICOEUR, 1995: 113). Sem pretendermos que são inadequadas interpretações anteriormente sustentadas por outros autores e mais pertinentes aquelas que agora possamos apresentar, não se nos afiguram totalmente inúteis algumas das hipóteses que aqui sugeriremos, nem totalmente infecundas certas interrogações que levantaremos.

Modelo novo, todavia, não nos sentimos capazes de propô-lo. Aliás, será que deveremos procurar um modelo? Ou haveria, nos povos da área aqui considerada, uma diversidade de organização social que não se pode reduzir a um modelo único? Não haveria até, no seio do um mesmo grupo, alguma diversidade? No que respeita, por exemplo, à matrilinearidade ou patrilinearidade, "é geralmente aceite que nenhuma sociedade é inteiramente matrilinear ou patrilinear quanto à filiação, sucessão, herança e autoridade" (RICHARDS, in RADCLIFFE-BROWN e FORDE, 1982:283, nota 2).

Renunciando, pois, à pretensão de apresentar um modelo novo, queremos suscitar dúvidas, formular problemas, apresentar, para alguns dados, novas hipóteses interpretativas, mesmo que, para estas, no nosso próprio juízo, não consigamos desenvolver argumentação suficiente para as validar ou tornar inteiramente convincentes e as nossas hipóteses tenham de permanecer conjecturas de momento indecidíveis.

A reconstituição histórica não poderá limitar-se a trabalhar com os dados que a Epigrafia proporciona. É certo que estes são fundamentais. Mas se os textos epigráficos são importantes, não o são menos os contextos. Não é irrelevante, por exemplo, que uma inscrição funerária em que o dedicado é integrado numa "unidade organizativa" designada por um genitivo do plural em -um se encontre isolada, no que poderia ser uma villa ou granja, ou seja única num sítio do qual procedam outras lápides funerárias sem tais genitivos, sítio que corresponda a vicus, castellum ou aldeia.

Ultimamente, ao mesmo tempo que uns continuam a explorar os dados proporcionados pela epigrafia, outros insistem na necessidade de ter em atenção também o registo arqueológico (SASTRE PRATS, 1998 e 2001). Este deve ser considerado quer no micro-nível, isto é, no das 
unidades residenciais ou de habitação no interior de um castro, quer no macro-nível, o das redes de povoamento em áreas mais ou menos consideráveis, desde a de uma civitas à de um populus. O nível médio de análise, que seria o da articulação das diversas unidades residenciais ou domésticas na área circunscrita pelas muralhas de um castro, é dificilmente praticável, dada a raridade de escavações extensas em povoados castrejos. O caso de Sanfins, bem analisado por Armando Coelho (SilvA, 1986: 43-46), não poderá, porém, deixar de ser considerado.

Com efeito, a dimensão dos lugares habitados e o seu posicionamento relativo no espaço físico não são apenas correlativos de uma determinada economia como também de uma certa estrutura de relações sociais. Por outras palavras, aspectos sociopolitícos intervêm na construção da paisagem e devem, pois, poder ler-se no espaço. Mas entre a análise espacial e a reconstituição das estruturas sociopolíticas existe um círculo hermenêutico: as estruturas sociopolíticas não se inferem ou deduzem das formas de povoamento nem a análise espacial serve para validar (ou não) as hipóteses que se formulam quanto à organização sociopolítica das comunidades. As duas análises (espacial e social) condicionam-se reciprocamente, de modo que, aqui, não há clara diferença entre o dado e o deduzido. Não pode, pois, através dos estudos de povoamento, verificar-se ou validar-se uma hipótese relativa à organização sociopolítica, mas apenas observar-se a compatibilidade ou coerência de uma determinada forma de povoamento com uma determinada estrutura sociopolítica, conferindo, a esta última, probabilidade ou verosimilhança.

Se da Arqueologia espacial poderão vir alguns esclarecimentos sobre a natureza e dimensão das "unidades organizativas" do Noroeste e Norte peninsulares, comparações com sociedades pouco complexas ou tradicionais que têm sido objecto de penetrantes estudos poderão também, eventualmente, sugerir pistas úteis de interpretação. Até da Antropologia filosófica, da Sociologia e da Etnometodologia poderemos receber contributos não despiciendos.

As "introduções", frequentemente, não dão conta de todos os temas ou de todas as propostas que depois, nos artigos ou obras de tomo, se abordam ou apresentam. É o caso desta nossa introdução. Terá ela servido, ao menos, para despertar a curiosidade e deixar suspeita de que valerá a pena ler-se o que se segue? 


\section{Os castella}

Diversas inscrições funerárias de indivíduos procedentes do Noroeste peninsular indicam a origo dos defuntos através de um etnónimo, seguido de um nome (em muitos casos, comprovadamente, um topónimo) precedido de um C invertido. Assim, por exemplo:

Caeleo, Cadroiolonis f(ilius), Cilenus, ? Berisamo (Albertos FIRMAT, 1975: 64)

Céleo, filho de Cadroiolo, Cileno (isto é, do populus dos Cileni), (natural) do castellum Berisamo

Foi $\mathrm{M}^{\mathrm{a}}$ de Lurdes Albertos quem reconheceu, no $\mathrm{C}$ invertido, a abreviatura de c(astellum) (Albertos Firmat, 1975 e 1977). À sua proposta aderiram de imediato muitos investigadores, enquanto outros manifestaram reservas. Não pretendendo resumir aqui a discussão que desde 1975 se tem gerado em torno deste problema (há resumos feitos por diversos autores, designadamente por RodRíGuez ColmENERO, 1995: 156 s. ou SASTRE PRATS, 2001: 186 s.), diremos que é hoje geralmente aceite que o C invertido está, nas inscrições por castellum (ou por ex castello), sem prejuízo de poder ter, nalgumas outras epígrafes, outro sentido, como defende A. Rodríguez Colmenero (1996: 156 s.).

Ao reunirem, pela primeira vez, todas as inscrições então conhecidas onde se regista o C invertido, Pereira Menaut e Santos Yanguas (1980) tornaram manifesto que tais inscrições se concentram nos conventus Bracarum e Lucensis ou se referem a indivíduos procedentes desses mesmos conventos.

Pereira Menaut e Santos Yanguas (1980: 127-129) observaram ainda que as inscrições com $\mathrm{C}$ invertido desaparecem nos finais do séc. I d.C. e equacionaram esse facto com a extensão do ius Latii a toda a Península Ibérica, por Vespasiano, em 73-74 d.C..

Por outro lado, a compilação, por Ma․ Cruz González Rodríguez (1986), de todas as inscrições com menção de gentes, gentilitates e genitivos do plural em -um ou -orum, tornou patente que "unidades organizativas" assim designadas se não registam naqueles dois conventus.

Passou a falar-se, assim, de uma área dos castella contraposta a uma área das gentilitates, nome que, por comodidade ou economia de expressão, se deu a esses genitivos do plural, aproveitando um termo 
que, todavia, só se encontra no famoso "pacto de Astorga", CIL II 2633 e numa inscrição de Oliva (Cáceres), CIL II 804.

Santos Yanguas (1985: 29) tornou-se advogado dessa distinção entre os conventus Bracarum e Lucensis, área dos castella, e o conventus Asturum, área de gentilitates. Nós mesmos subscrevemos esta ideia (AlARCÃO, 1999 (1)).

Assim, se, nos conventus Bracarum e Lucensis, os indivíduos indicavam a sua origo através da menção do castellum e do populus, no conventus Asturum indicariam a procedência através de um genitivo do plural, em raros casos precedido de ex gente, como nos exemplos seguintes (GoNZÁLEZ RodRíGUEZ, 1986, C. 159 e C. 6):

\author{
$s($ itus $)$ \\ Aravo, Oilaridum, Licin(i)f(ilio), a(nnorum) LI. H(oc) l(oco)
}

A Aravo, dos Oiláridos, filho de Licínio, de (falecido com) 51 anos. Aqui jaz.

M(onumentum) po(situm). Dib(us) Ma(nibus). Anto(nio) Pate(rno), an(norum) LX, ex gen(te) Ablaidacoru(m). Fil(ius) p(atri) po(suit)

Aos deuses Manes. Monumento erguido a António Paterno, da gens dos Ablaidacos, de (falecido com) 60 anos. O filho consagrou ao pai.

$\mathrm{O}$ aparecimento do $\mathrm{C}$ invertido em inscrições do conventus Asturum, onde antes se julgava existirem apenas gentilitates, veio lançar dúvidas sobre a mútua exclusão dos dois mundos: o dos castella e o das gentilitates. Adiando a discussão deste problema, faremos um desvio para investigarmos como poderia indicar-se a origo, mesmo depois de se ter abandonado o $\mathrm{C}$ invertido.

\title{
3. Indicação de origo sem $\mathrm{C}$ invertido
}

Não podemos deixar de observar que o abandono do $\mathrm{C}$ invertido não significou abandono absoluto do hábito de indicar, como origo, um castellum ou lugar secundário no interior de uma civitas.

Sem qualquer pretensão de exaustividade, e apenas a título de exemplo, citaremos três inscrições: 
De Cória (Cáceres) ( HuRTAdo de SAN ANTóNIO, 1977: 123): Aemilius Marcellus, Marci f(ilius), Arcobrigensis, ann(orum) XXXXV, h(ic) s(itus) e(st). S(it) t(ibi) t(erra) l(evis). Titus, [P]ere[g]rin[i] f(ilius) et Crescens [...]

De Tarouquela (Cinfães) (ENCARNAÇão, 1975: 235-237):

Mirobieo loco Abrui Arqui ... [...] apiobicesis

De Santo Estêvão (Sabugal) (CuRAdO, 1984):

Cumelius, Corobulti f(ilius), Cularni, fecit, de Balatucelo nat(ione)

Relativamente à primeira inscrição, não temos qualquer prova de que esta Arcobriga seja a da actual província de Saragoça, citada por Plínio, III, 4, 24. Possivelmente corresponde a um lugar secundário integrado na citivas de Caurium.

Na segunda das citadas inscrições, [...] apiobicesis designa certamente um natural de um lugar secundário (Apiobica? Apiobicum?) que ficaria no território da civitas dos Paesuri (sobre a localização destes, vid. AlarCão, 2001: 47 e AlarCão, 2000(1): 166).

Em ambas as inscrições, a referência a um lugar secundário, sem menção da civitas correspondente, deixa-nos supor que esse lugar ficava no interior da civitas onde a inscrição foi erigida. Por outras palavras: um indivíduo, deslocando-se de um lugar secundário para outro lugar secundário dentro da mesma civitas, ou para a própria capital da civitas, poderia indicar, como origo, o lugar secundário de onde provinha, sem indicar a civitas. Um outro indivíduo, deslocado da sua civitas de origem para outra diferente, poderia indicar o seu lugar de origem, mesmo que fosse um lugar secundário, mas indicaria também a civitas em que o seu lugar de origem se situava. Este parece ser o caso do Cularnus, oriundo de um castellum Balatocelum. Cularni será uma variante gráfico-fonética de Coilarni, civitas que teria por capital a actual cidade de Lamego (sobre esta localização, vid. ALARCão, 2000 (1): 166-167).

Admitindo que tenha realmente existido a norma que acabámos de definir, não deixaremos de aceitar também que, na prática, a regra pode ter sido frequentemente infringida ou não observada. A título de exemplo, e sem procurarmos outras excepções, citaremos o caso de $\mathrm{Gr}$ (anii??) Pater(ni?), Quir(ina tribu), Cae(sarobrigensis), ex cas(tello) Ciseli 
(Mangas e Olano, 1995: 341). Achada em Talavera de la Reina (Toledo), que corresponderá a Caesarobriga, a inscrição refere um Grânio Paterno que terá vindo de um lugar secundário da civitas para a capital da mesma civitas e a esposa, que lhe tratou da lápide funerária, indicou o lugar de origem e também a civitas em que tal lugar se integrava. De acordo com o que seria a norma, a indicação de Caesarobrigensis seria desnecessária. Não devemos esquecer, porém, a possibilidade da leitura Cae(lius) por Cae(sarobrigensis) (AlBERTOS FIRMAT, 1977: 20).

Nenhum dos exemplos anteriormente dados se reporta ao Noroeste. Mas, na área do conventus Bracarum, podemos encontrar exemplos semelhantes:

De Braga (CIL II 2419)

[Ce]licus Fronto, Arcobrigensis, Ambimogidus, fecit. Tongoe Nabiago

De Braga (Tranoy e Le Roux, 1989-1990: 202)

Severus, Reburri f(ilius), Tiophilus, Elaneobrigensis, an(norum) $X X X X$, sodales Flavi d(e) s(vo) f(aciendum) c(uraverunt)

Relativamente à primeira inscrição, temos de novo (como na epígrafe anteriormente citada de Cória), uma Arcobriga, sem que possamos demonstrar, nem sequer defender com grande margem de probabilidade, que, nos dois casos, se trata do mesmo povoado (apesar do que sugeriu Tranoy, 1981: 285). Nesta inscrição, o nome Ambimogidus, que Tranoy (1981: 284) considera como relativo a um clã, poderia ser o do populus ou civitas de procedência de Celicus Fronto. Se bem que Ambimogidi nos pareça um estranho etnónimo, talvez não seja de excluir totalmente a hipótese de corresponder à civitas que teve por capital a cidade de Tongobriga e cujo forum e termas foram há poucos anos revelados (DiAs, 1997). Aliás, já Ma․ Lurdes Albertos admitiu a possibilidade de Ambimogidi corresponder a um etnónimo (ALBERTOS FIRMAT, 1975: 47, n. ${ }^{\circ}$ 64).

Quanto ao Elaneobrigensis, também não temos provas de que proceda de uma capital de civitas. Se bem que uma capital chamada Elaneobriga não seja uma impossibilidade, não é menos verosímil que Elaneobriga tenha sido um castellum no interior da civitas de Bracara Augusta. Tendo-se deslocado do seu castellum de origem para a cidade capital, Severus Teophilus terá sido sepultado com menção do 
lugar de nascimento mas sem referência à civitas, de acordo com a suposta norma.

As observações que acabámos de fazer podem ter algum interesse e justificariam, certamente, o estudo sistemático destas menções de origo formadas, a partir de um topónimo, pelo sufixo -ensis, menções que parecem corresponder, algumas vezes, a lugares secundários. Mas são irrelevantes para a questão que agora deveremos abordar: a menção de castella como origo, bem documentada para os conventus Bracarum e Lucensis, também se encontra no conventus Asturum?

\section{Castella no conventus Asturum}

As inscrições que Júlio Mangas e Manuel Olano (1995) reuniram, encontradas no conventus Asturum, com menção de castella ou castellani, podem (ou devem) incluir-se em três grupos: as que recordam imigrantes; as de El Bierzo; as dos Astures Transmontani.

\subsection{As inscrições de imigrantes}

Duas inscrições reportam-se a imigrantes vindos do conventus Lucensis. Não provam, pois, que os naturais do conventus Asturum também indicavam, como origo, um castellum. Referimo-nos à lápide funerária, encontrada em Astorga (ERPL, n. ${ }^{\circ}$ 155), que regista uma Fabia, Eburif(ilia) e um Virius, Caessi f(ilius), ambos procedentes do castellum Eritaeco (reproduzimos a forma do topónimo tal como se encontra na inscrição, com possível nominativo *Eritaecum), castellum que se situava no âmbito do populus ou da civitas dos Lemavi; e à inscrição, procedente de Ablaneda (Salas, Astúrias) que recorda um Flaus, Auledi f(ilius), Cabarcus, c(astello) Beriso (Albertos Firmat, 1975: 64, n. ${ }^{\circ}$ 6). Ambos os populi, Lemavi e Cabarci (ou Cibarci) eram Lucenses (TRANOY, 1981: 56 e 58).

\subsection{As inscrições de El Bierzo}

A área conhecida pela designação de El Bierzo, incluída na actual província de León, tem uma individualidade própria e constitui uma 
zona que, pelas suas características, não se pode integrar facilmente nem na Galiza nem nas Astúrias (MAÑANES, 1981). O falar das suas gentes aproxima-se, porém, do moderno galego (Dopico CAínzos, 1988: 20).

A divindade indígena Cosus, adorada também nos conventus Bracarum e Lucensis, conta com numerosos testemunhos em El Bierzo (FERNÁNDEZ-Albalat, 1990; PróSPER, 2002). Mas no conventus Asturum, excluída aquela área, temos apenas uma inscrição a Cosiovi Ascanno ou Cos(...) Ioviascanno (PRÓSPER, 2002: 234 e 237-238) em S. Mamed de las Rozas (Villablino, León), no curso superior do rio Sil, e uma outra a Consus (que PRóSPER, 2002: 243-244, considera forma hipercorrecta de Cosus) em S. Pedro de Trones (León). Quanto à inscrição de Grases (Villaviciosa, Astúrias), lida como D(eo) [Coss]iovio Tabaliaeno, tem sido restituída por outros como [Dul]ovio ou [Deo]Lovio e Blanca María Prósper (2002: 234) propõe Iovio Tabaliaeno. É, pois, muito incerto o testemunho de Grases. As localidades de S. Mamed de las Rozas e S. Pedro de Trones ficam no extremo ocidental da província de León, confinante com a de Orense, que integra o conventus Lucensis.

Não podemos, pois, deixar de perguntar-nos se El Bierzo, incluído pelos Romanos no âmbito do conventus Asturum, não teria afinal, na época pré-romana e, eventualmente, na própria época romana, mais afinidades com o conventus Lucensis do que com os outros populi administrativamente integrados no conventus Asturum. O assunto, porém, merecia mais estudo do que aquele que aqui podemos fazer.

Em S. Andrés de Montejos (Ponferrada), encontrou-se uma inscrição Iovi ? Queledini (ou Quelediani) (ERPL, n. $\left.{ }^{\circ} 46\right)$. O C invertido, neste caso, não deve desdobrar-se em (ex) c(astello), mas em castellani, como mostrou Mª . Lurdes Albertos, que restitui um topónimo *Queledium (AlBertos Firmat, 1977: 22). A inscrição, votiva e não funerária, não indica uma origo. Demonstra, isso sim, que também no conventus Asturum os castros eram chamados castella — o que não tem nada de surpreendente. Com efeito, para além de outras cuja pesquisa, neste momento, consideramos inútil, a inscrição de Talavera de la Reina (Toledo) atrás citada, com menção ex cas(tello) Ciseli e a dos castellanis Araocelensibus (em dativo), em S. Cosmado (Mangualde, Viseu) (ALARCÃo, 1988, n. ${ }^{\circ}$ 4/216) provam quão generalizada seria a designação de castella para os castros.

$\mathrm{Na}$ mesma área de El Bierzo encontramos ainda o castellum *Aiobaigiaecum (se é este o nominativo que deve deduzir-se do ablativo ou 
genitivo de origem Aiobaigiaeco) e o castellum Toletum, respectivamente, dos Susarri e dos Lougei (na téssera de O Caurel, ARIAS VILAS, Le Roux e Tranoy, 1979: 75), bem como os catellani Paemetobrigenses ex gente Susarrorum e os castellani Aiiobrigiaecini ex gente Gigurrorum (no "bronze de Bembibre", GRAu e HoYAs, 2001).

Ainda da região de El Bierzo procedem a ara à deusa Cenduedia, achada em San Esteban de Toral (Bembibre) e posta por uns castellani que se não nomeiam (ERPL, n. ${ }^{\circ}$ ).

\subsection{Inscrições dos Astures Transmontani}

As epígrafes anteriores permitem manter a hipótese de uma área de castella distinta de uma área de gentilitates, sem que a fronteira tenha coincidido exactamente com o limite político-administrativo (artificial) entre os conventus Lucensis e Asturum. Não podemos, porém, ignorar que há, relativamente aos Ástures que Plínio, III, 4, 28 designa por Transmontani, testemunhos de castella mencionados como origo.

Se a inscrição do museu de Oviedo, [...] Alexi[...] ex ? [...] (MANGAS e OlANO, 1995: 346) não constitui prova nenhuma segura, quer por estar muito incompleta, quer por não ser conhecida a sua proveniência, já é mais difícil não dar valor a outras epígrafes:

- CIL XIII 8098 (= Le RouX, 1982: 192, n. 75 bis), que regista um Pintaius, Pedicilif(ilius), astur transmontanus, castello Intercatia. Sendo desconhecida a localização desta Intercatia, é evidente que ficava na parte setentrional do conventus Asturum.

— HEp. 5, 1995, n. ${ }^{\circ} 39$ (= MANGAS e Olano, 1995: 345), inscrição funerária posta a uma Bodocena, Aravi f(ilia), procedente do c(astellum) Agubri. Se é certo que não se menciona o populus ao qual Bodocena pertencia, também nada nos autoriza a considerar que o castellum ficava na área do conventus Bracarum ou Lucensis ou na área de El Bierzo. Se Villaverde (Belmonte de Miranda, Astúrias), lugar onde se encontrou a epígrafe, ficava na área dos Paesici (sobre a localização destes vid. TRANOY, 1981: 50), parece mais credível considerar o castellum Agubri como integrado neste populus dos Astures Transmontani. 


\section{Uma proposta a partir da inscrição de Serrapio}

Em Serrapio (O Aller, Oviedo), num local por onde passava a via romana de Puerto de San Isidro a Ujo, foi encontrada uma inscrição votiva com o seguinte texto: Iovi Optimo et Maxsumo sacrum. Arronidaeci et Coliacini, pro salute sibi et suis, posuerunt (DIEGo SANTOS, 1959, n. ${ }^{\circ}$ 1; CIL II 2697).

Ao apresentar esta inscrição, Pereira Menaut (1982: 252, nota 8) perguntou-se se Arronidaeci e Coliacini seriam gentilitates ou populi. Inclinou-se o autor para a segunda hipótese. A. Tranoy, por sua vez, manifestou a mesma dúvida entre a classificação dos Arronidaeci e Coliacini como gentilitates ou populi (Tranoy, 1981: 319 e 370-371). A verdade, porém, é que não temos segundo testemunho com estes nomes, testemunho que possa (ou deva) inclinar-nos para a sua aceitação como nomes de populi. Não sendo impossível que dois populi se reunissem no mesmo local, eventualmente fronteiriço, para, em conjunto, erigirem uma inscrição a Júpiter, outras duas possibilidades parecem mais verosímeis: a de que a ara tenha sido consagrada pelos habitantes de dois castella, também em lugar fronteiriço, ou por duas gentilitates residentes no mesmo castellum. No primeiro caso, teríamos uns castellani Arronidaeci e uns castellani Coliacini; no segundo, uma gentilitas Arronidorum (ou Arronidaecorum? ou Arronidaecum?) e uma gentilitas Coliacorum (ou Coliacinorum?), cujos membros se poderiam dar a eles mesmos também os nomes de Arronidaeci e Coliacini.

Mais adiante, iremos sustentar que as gentilitates Desoncorum e Tridiavorum do "pacto de Astorga", CIL II 2633, viviam na mesma aldeia ou vicus. Poderemos, assim, reforçar a hipótese de Arronidaeci e Coliacini viverem no mesmo castellum, isto é, serem conviventes (achando-se este último termo atestado numa inscrição de Pedrosa del Rey, interpretada por Mํ. Cruz Rodríguez, 1997: 96 s., e para a qual proporemos um novo entendimento).

A objecção que pode levantar-se à interpretação de Arronidaeci e Coliacini como nomes de gentilitates reside em que o sufixo-aecus, próprio do Ocidente hispânico, serve, normalmente, para formar epítetos teonímicos e etnónimos a partir de nomes de lugares (BÙA, 1997: 57), enquanto o sufixo latino -inus, com variante -anus (correspondente a um sufixo indo-europeu -īno), servia para formar etnónimos igualmente a partir de nomes de lugares (PRÓSPER, 2002: 300). Teríamos, 
assim, um castellum *Arronidum ou *Arronitā (BúA, 1997: 57) e um castellum *Coliacum.

A verdade, porém, é que o sufixo -aecus tem, como alomorfos, -ecus, -eicus e -icus, entre outros, e este sufixo encontra-se nos nomes de certas "unidades organizativas", como, por exemplo, Boutiecum, Caburateiqum ou Cadaricum (GonZÁlez RodRíGUEZ, 1986: 138), derivados de antropónimos, Boutius, Caburus ou Cadus (ABAsCal PalAZÓN, 1994). Assim, o nome Arronidaeci poderia ser o de uma "unidade organizativa" (ou gentilitas), formado a partir de Arronus, com acrescento de um - $d$ - intervocálico. Não se tendo registado na Península Ibérica, até agora, o nome Arronus, não estará ele, porém, na base do genitivo do plural Aroniaecivorum (GonZÁLEZ RodRíGUEZ, 1986: C. 39)? Ou não será Arronus uma variante de Arrenus ou Arreinus, como aliás, Untermann (1995: 60-61) parece considerar? (Sobre os antropónimos Arreinus e Arrenus vid. também ABASCAL PALAzón, 1994: 286). De qualquer forma, não parece fácil equacionar os Arronidaeci desta inscrição de Serrapio com o populus dos Arroni de Plínio, situados no conventus Lucensis (TRANOY, 1981: 54).

Quanto ao elemento -inus, será, em Coliacini, um sufixo? A existência de antropónimos em -ginus (GoNZÁLEZ RoDRÍGUEZ, 1997: 99-100), bem como a possibilidade de Coliacini estar por Coliagini, talvez autorize a pensar que este nome seja o nominativo do plural designativo de uma gentilitas cujo genitivo seria Coliacinorum ou Coliacinum. Do mesmo modo, *Ubalacinus terá dado origem ao genitivo do plural Ubalacino(rum) (GonZÁLEZ RodRíGUEZ, 1986, C. 189. Cfr. todavia GonZÁLEZ RODRÍGUEZ, 1997: 117, nota 358, admitindo Ubalacino como antropónimo e duvidando da restituição Ubalacino(rum) que faria, do nome, um genitivo do plural).

Poderá ainda não ser rejeitável a hipótese de termos, em Coliacini, um caso de dupla sufixação, com -aecus ou -acus seguido de -inus, que derivaria de $*$ Colius ou *Coilius, antropónimo não registado na Península Ibérica mas eventualmente presente em Coilionicum e Coilionqum (GonzÁlez RodRíGuEZ, 1986, C. 93 e 94, ambos de Yecla de Yeltes, Salamanca). Se restituíssemos Coilion(i)qum, teríamos, em Yecla de Yeltes, duas atestações do mesmo genitivo do plural. Por outro lado, -anus é alomorfo de -inus e encontra-se em Magilanicum (GoNZÁLEZ RodRíGUEZ, 1986, C. 137), genitivo do plural que permite restituir um nominativo Magilanici, a partir de Magilo, amplamente atestado como nome pessoal (ABASCAL PALAZÓN, 1994), 
com dupla sufixação -anus e -icus. A dupla sufixação estaria aqui invertida, relativamente a Coliacini.

A reforçar a hipótese de Arronidaeci e Coliacini serem gentilitates, temos, na inscrição, a fórmula pro salute sibi et suis, que parece mais adequada a "unidades organizativas" ou familiares que a castellani ou populi, ainda que a inscrição Dis deabusque omnibus pro salute castellanorum Vervassium(CIL V 5059) nos obrigue a aceitar que se podiam formular votos pro salute de uns castellani. Mª . Cruz González Rodríguez (1986: 61-62) admite que as "unidades organizativas" possam ser designadas por nomes formados pelo sufixo -icus aposto a antropónimos e Blanca Maria Prósper (2002: 307) admite a sequência *aK-ìno (interpretável como duplo sufixo), que poderia, eventualmente, explicar Coliacini a partir de um topónimo *Colia ou Colua. Se não temos atestação do primeiro, têmo-lo do segundo (VILLAR, 2000: 175).

Na hipótese de, pelo menos em alguns castella dos Ástures, terem coexistido duas ou mais gentilitates, o caso de Pintaius, astur transmontanus, castello Intercatia poderia interpretar-se neste sentido: em Intercatia conviviam duas ou mais gentilitates; a Pintaius, sepultado em Colónia (Germânia), não teria sido posta lápide com indicação da gentilitas mas apenas com a do castellum, por ser a gentilitas pouco significativa para os seus companheiros de armas, ou mesmo para quem se encarregou do funeral. Para viabilizar esta hipótese, podemos citar P. Bourdieu (1994: 280-281), que adverte para a frequência com que a origem ou identidade é manipulada: o mesmo indivíduo pode, consoante as circunstâncias, as situações ou os interlocutores, identificar-se ou ser identificado como pertencente a uma determinada família ou apenas como pertencente a uma determinada tribo. Entre os Kabilos do Magreb, um homem pode ser identificado como membro de uma "casa" (akham), isto é, da unidade mais restrita, ou como membro da unidade mais abrangente, a tribo ( $\hat{a} a r c h)$.

Contrariando a nossa própria argumentação, podemos todavia dizer que Pintaius era membro de uma coorte dos Ástures na qual se deveriam contar muitos outros Ástures, mesmo, como ele, Transmontani, e que, portanto, nesse meio militar concreto, as gentilitates poderiam manter todo o seu significado. Mas também poderemos supor que os Ástures dessa coorte omitiam a gentilitas de origem, que os dividia, para salientarem a pertença a um castellum, donde poderiam provir vários dos alistados na coorte e a uma região, a Asturia transmontana. Não deixa de surpreender que se não indique o populus ou a civitas de 
onde procedia Pintaius, pois a sua Intercatia não parece ser a que foi, possivelmente, capital dos Orniaci (Ptolemeu, II, 6, 31), uma vez que estes se situariam entre os Astures Augustani (Tranoy, 1981, 49-50).

Quanto à inscrição de Bodocena, ? Agubri, poderíamos admitir o uso do $\mathrm{C}$ invertido como abreviatura de gentilitas ou gens. Mas, também aqui, poderemos argumentar que, à vista de c(astello) Ercoriobri ou c(astello) Letiobri (ALBERTOS FIRMAT, 1977: 22-23), a restituição c(astello) Agubri é perfeitamente viável, e mesmo mais credível.

As nossas hipóteses interpretativas visavam defender ou confirmar a ideia de uma área em que a origo se indicava através do castellum (isto é, a área dos conventus Lucensis e Bracarum e de El Bierzo), distinta de uma outra (a do conventus Asturum, excluída essa mesma região de El Bierzo) em que se não usaria, para indicar a origo, o castellum mas a gentilitas (salvo o caso, que procurámos explicar como singular, de Pintaius, astur transmontanus). Se tal ideia não ficou validada, a ideia contrária, de que o conventus Asturum corresponde a uma área onde coexistem diversos sistemas de identificação, dificilmente explicáveis ou explicáveis apenas pelo recurso à ideia de uma zona de grande heterogeneidade, eventualmente por ser zona de transição (GoNZÁLEZ RodRÍGUEZ, 1997: 73, 76-77 e 81; MANGAS e OlANO, 1995: 345-347; Fernández OCHOA e Morillo CERdÁn, 1999: 29-30), parece dever aguardar novas descobertas epigráficas que permitam esclarecer melhor o assunto.

\section{A organização social no interior dos castella dos conventus Bra- carum e Lucensis}

Na área dos conventus Bracarum e Lucensis (como, aliás, também na do conventus Asturum), a maior parte dos castros ou castella da Idade do Ferro (como daqueles que se mantiveram na época romana ou foram instalados neste último período) tinha pequenas dimensões.

$\mathrm{Na}$ "comarca lucense", cujos castros foram inventariados por E. González Fernández e S. Ferrer Sierra (in Rodríguez Colmenero, 1996: 329-417), 14 povoados, representando 35,9\% dos castros registados, têm menos de 0,5 hectare; $16(=41 \%)$ têm entre 0,5 e 1 hectare; e apenas $1(=2,5 \%)$ tem entre 1 e 2 hectares (tendo sido indeterminável a área de 8 povoados $=20,5 \%$ ). 
Na bacia média do rio Ulla, 29,4\% dos castros têm menos de 0,5 hectare; $47,1 \%$ caem no intervalo de 0,5 a 1 hectare; $13,2 \%$ têm 1 a 1,5 hectare; 7,4\%, entre 1,5 e 2 hectares; apenas 2,9\% alcançam o intervalo de 2 a 2,5 hectares (CARBALlO ARCEO, 1990: 169).

Os castros da bacia do rio Cabrera têm, em média, 0,38 hectares de área habitada e esta área não excede, no maior, 0,82 hectare; para a bacia do rio Eria, a média é de 0,53 hectare, tendo o maior, 1,03 hectare (FernándeZ-Posse e SÁncheZ-PAlencia, 1998: 202). O castro de La Corona de Corporales teria 174 ou 175 habitantes e o Castro de Corporales, 194 ou 195 (id.: 227).

Para a área do conventus Asturum que hoje se integra em território português, dispomos de um excelente inventário dos castros que, todavia, não indica as respectivas superfícies (LEMOS, 1993). Mas, julgando pela reduzida aptidão dos solos nos territórios de 30 ou de 60 minutos dos castros dessa área (CRUZ, 2000), não parece que os povoados possam ter sido senão pequenos (com algumas poucas eventuais excepções). Nos inventários de Armando Coelho (SiLva, 1986), Manuela Martins (1990) ou Esparza Arroyo (1986) também não encontramos, infelizmente, as superfícies habitáveis dos castros.

Não esquecemos que havia grandes castros, de que, no território actualmente português, as citânias de Briteiros (Guimarães) e Sanfins (Paços de Ferreira) são os exemplos mais conhecidos. A muralha interna de Briteiros envolve 3,75 hectares (mas há habitações entre a muralha interna e a média) e a muralha 2 de Sanfins (que envolvia a área habitada) representa cerca de 7 hectares. Numa ratio de 300 habitantes/hectare, a citânia de Briteiros teria 1125 habitantes e a de Sanfins, 2100 (AlARCÃO, 1992: 56-57, com cálculos sobre a capacidade de sustentação que já na altura nos pareceram grosseiros por não considerarem áreas potencialmente agricultáveis, mas sem que a revisão desses mesmos cálculos afecte a hipótese, por nós posta, de povoados cuja população não podia sustentar-se com os recursos dos territórios de exploração directa, devendo, por isso, ser parcialmente abastecida com recursos proporcionados por outros castros possivelmente dependentes).

Ainda que admitamos a ratio, provavelmente excessiva, de 300 habitantes/hectare (RENFREW, 1972: 394), a maioria dos castros teria menos de 250 habitantes, isto é, menos do que o correspondente a 50 famílias nucleares (de 5 indivíduos por família). Provavelmente, muitos dos castros teriam bem menos que 250 habitantes e poderiam comparar-se às aldeias medievais dos séculos XI a XIII, que raramente excede- 
riam 20 fogos (AlARCÃo, 1996: 19). Mesmo admitindo aquela elevada ratio de 300 habitantes/hectare, 35,9\% dos castros da "comarca lucense" e 30\% dos da bacia do rio Ulla teriam, no máximo, 150 habitantes, número que não seria ultrapassado pela maioria dos povoados das bacias dos rios Cabrera e Eria. Para a bacia do Ulla, L. X. Carballo Arcea (1990: 187-188), admitindo, como hipótese, as rationes alternativas de 100 e de 300 habitantes, obteve, para o pequeno castro de Salgueiros, com 0,23 hectare, um cômputo de população entre 23 e 70 habitantes e para o de Cartimil, com 2,18 hectares, o intervalo de 218 a 645 habitantes.

Um tecto de 150 habitantes parece significativo em termos de reconhecimento recíproco dos vizinhos concentrados num mesmo local. Na Nova Guiné, 52,8\% dos povoados tradicionais tinham entre 75 e 300 habitantes e estes números não podem explicar-se exclusivamente por razões ecológicas, isto é, por dificuldades de abastecimento que os habitantes sentiriam se os povoados ultrapassassem tais números. Segundo a sugestão de Anthony Forge (1972), não se pode ultrapassar um determinado número de vizinhos ou conviventes num povoado sem que se caia em dificuldades de identificação do(s) interlocutores e mesmo em determinados conflitos ou tensões sociais. Acima de 150 habitantes - o que corresponde a cerca de 35 varões adultos — , torna-se necessária, segundo o mesmo autor, alguma forma de "segmentação" da população ou, por palavras menos equívocas, alguma forma de unidades integradoras superiores à família nuclear.

Quer isto dizer que, teoricamente, a população de cerca de $30 \%$ dos castros poderia viver sem unidades superiores à família nuclear (a conta de $30 \%$ baseia-se, aqui, nos dois casos da "comarca lucense" e da bacia do rio Ulla). Mas uma percentagem talvez considerável (todavia difícil de computar) teria de organizar-se em unidades superiores a famílias desse tipo. Tais famílias podiam ser indivisas ou alargadas (em inglês, joint families), isto é, constituídas por, pelo menos, um casal fundador, seus filhos e os filhos daqueles filhos. Podemos perguntar-nos se, nos castros menores, sendo teoricamente dispensáveis, não existiriam também, afinal, famílias alargadas. O problema é complexo e não pode ser abordado sem considerar o factor "tempo". Com efeito, parecendo que, pelo menos em certas áreas, os grandes castros são de formação tardia no longo período da Idade do Ferro, não se terá dado uma evolução das famílias nucleares originais (dos pequenos castros) para as alargadas ou indivisas (dos grandes povoados)? 
Põe-se-nos agora um outro problema: o de saber se tais famílias alargadas constituíam unidades domésticas (ou de residência), isto é, se todos os membros de uma família alargada viveriam sob o mesmo tecto e constituíam unidades de produção e consumo.

O problema é difícil de tratar, quer por ser muito reduzido, nos castros do Norte e Noroeste, o número de unidades residenciais claramente identificadas, quer por serem muito discrepantes as rationes $\mathrm{de}^{2}$ por habitante que têm sido propostas. Com efeito, se são muitas as casas castrejas escavadas em numerosos povoados, não podemos deixar de perguntar-nos: a cada casa corresponde uma família? Ou, por outras palavras: cada casa é uma unidade doméstica ou residencial? Ou várias casas comporiam uma unidade doméstica, não sendo reconhecidos, na maior parte dos castros escavados, os grupos de casas correspondentes a cada unidade? A melhor ideia do que deve entender-se por unidade doméstica ou residencial retira-se da que, na citânia de Sanfins, foi reconstruída por Armando Coelho e Rui Centeno (nossa est. I).

Sem pretendermos fazer um estudo tão exaustivo quanto seria possível ou desejável, referiremos alguns casos. Assim, na planta de cividade de Terroso levantada em 1906-1907 (SILVA, 1986,est. XVII), não são discerníveis agrupamentos, que, todavia, parecem começar a reconhecer-se em planta mais cuidadosa (SILVA, 1986, est. XVIII). No castro de Vilar (na serra de El Caurel) identificaram-se casas com superfícies de 7,05 a 49,50 $\mathrm{m}^{2}$ e, no castro de Torre de Castro (na mesma serra), casas de 10,70 a 27,55 m² (LuZÓn NoguÉ e SÁnChez-PALENCIA, 1980: 90). Mas em nenhum destes castros é claro que uma casa corresponda a uma unidade residencial.

No povoado de Corona de Corporales, a unidade de habitação que F. Sánchez-Palencia e Mª Dolores Fernandéz-Posse (1985) designam por "construcciones en torno a la calle A", integrando as divisões 1 a 5, totalizava, na sua forma final, $96 \mathrm{~m}^{2}$ de área coberta. Supõem os autores que correspondia a uma família nuclear e consideram que tais famílias teriam, em média, 4,65 indivíduos (id.: 227). A ser assim, obter-seia uma ratio de $20 \mathrm{~m}^{2}$ de área coberta por habitante — o que parece dificilmente aceitável, por corresponder ao dobro da área proposta por Naroll (1962) e esta ser geralmente considerada excessiva (HASSAN, 1982: 231-233): Casselbery admite $6 \mathrm{~m}^{2}$ e Hill, 4,55 $\mathrm{m}^{2}$ por habitante (citados por HASSAN, 1982: 232-233).

$\mathrm{Na}$ cividade de Âncora, uma unidade claramente delimitada por Armando Coelho (SILVA, 1986: 48) tem 57,5 m² de área coberta (nossa 
est. II). Admitindo que era a residência de uma família nuclear de casal e três filhos, teríamos mais de $11 \mathrm{~m}^{2}$ por habitante — o que, sendo inferior ao proposto para Corona de Corporales, parece ainda excessivo.

Por outro lado, a ratio de $4,55 \mathrm{~m}^{2}$ de área coberta por indivíduo daria, para a unidade de Âncora, 12 habitantes e, para a de Corona de Corporales, mais de 21 ocupantes. Temos dificuldade em aceitar esta contra-proposta, por nos parecer que peca por excesso, agora em sentido contrário.

Aceitando a proposta de Casselbery, de $6 \mathrm{~m}^{2}$ por habitante, a unidade residencial de cividade de Âncora teria entre 9 e 10 habitantes, o que corresponderia a uma família trigeracional como a do seguinte schema:

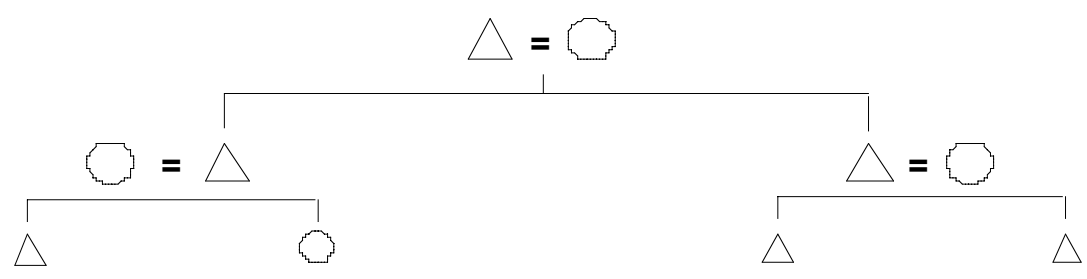

FIG. 1

Ora a referida unidade residencial de Âncora tem uma casa com banco corrido a toda a volta, pelo interior, com assento para 32 indivíduos (SILVA, 1986: 268, talvez com erro de 32 por 50). Obviamente, a capacidade desse banco excede a habitabilidade da unidade residencial.

Não nos queremos agora pronunciar sobre o que era a syngéneia referida por Estrabão, III, 3, 7. Para Armando Coelho (SiLvA, 1986: 268), era uma família alargada; para Ma . Cruz González Rodríguez (1994: 146-154 e 1997: 62-64), era a reunião da "elite dos distintos grupos de população menores que formam parte do ethnos dos Ástures", isto é, dos indivíduos principais dos brigaecinos, lancienses, lugones, etc. Fosse como fosse, a existência destes bancos em várias casas sugere a existência de banquetes familiares e o banco da casa da cividade de Âncora estava preparado para alojar muito maior número de convivas do que aqueles que podiam residir nessa unidade doméstica. Isso levanos a supor que nesse banco se reuniria uma família alargada e que esta integrava diversos ramos, um dos quais residiria na referida unidade e outros habitariam noutras unidades domésticas. Poderemos, talvez, 
falar de uma linhagem, tendo à frente, residente na dita unidade doméstica, o casal fundador e alguns descendentes ou o varão mais próximo, por primogenitura, do fundador da linhagem. Recorrendo ao schema da fig. 2, poderemos imaginar que, sendo já falecido o casal fundador, naquela unidade doméstica residiria o núcleo familiar que na nossa figura inscrevemos no círculo $\mathrm{A}$. Os círculos $\mathrm{B}$ e $\mathrm{C}$ corresponderiam a outras unidades residenciais. As unidades familiares B e C reunir-seiam todavia na residência da unidade A para os banquetes familiares.

A existência, na mesma cividade de Âncora, de uma casa com banco no qual caberiam cerca de 50 indivíduos (SILVA, 1986: 268) permite supor que as famílias alargadas poderiam atingir esse número de membros.

A unidade familiar residente numa unidade doméstica não cresceria, assim, indefinidamente (quanto mais não fosse, por razões de espaço). A certa altura, um indivíduo abandoná-la-ia para criar outra unidade doméstica. É possível que os "desertores” fossem secundogénitos ou filhos de secundogénitos, por altura dos seus casamentos. Mas não consideramos forçoso que o fossem. Podemos admitir que, mesmo tendo sido essa a regra, sofresse numerosas excepções, sem que elas causassem qualquer sentimento familiar ou público penoso, de infracção aos mores maiorum ou às práticas sociais. Entre parentes, vivendo sob o mesmo tecto, há afinidades e desentendimentos, estes por vezes temporários, que poderiam justificar a "deserção" de um sénior em vez de um posterogénito.

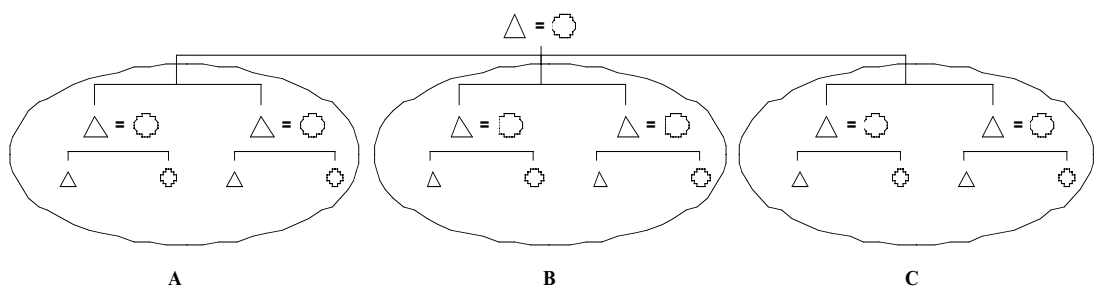

FIG. 2

Por outro lado, a independência adquirida pelo novo "lar" poderia ser progressiva. De início, enquanto o casal não tinha filhos (ou mesmo que os já tivesse, mas enquanto fossem pequenos) poderia integrar a unidade de produção que corresponderia à unidade doméstica da qual acabara de isolar-se. 
Armando Coelho (SILVA, 1986: 46) apresentou um quadro esquemático extremamente interessante das unidades domésticas de Sanfins, quadro que reproduzimos na nossa Est III.

Como se verifica, a composição das unidades residenciais é muito variável, desde as que integram numerosas "peças" (como F2b, F3a ou F4a), às que se reduzem a duas "peças" (como F1 ou I2b).

Tanto quanto podemos julgar pela planta publicada por Armando Coelho (1986: 45, Fig. 7), a unidade F1b teria cerca de $75 \mathrm{~m}^{2}$ de área coberta. Poderia, pois, alojar 7 ou 8 a 16 habitantes (consoante aceitemos a média de 10 ou $4,55 \mathrm{~m}^{2}$ por indivíduo). A unidade F1d, apenas com uma casa redonda e uma rectangular, num total de cerca de $40 \mathrm{~m}^{2}$, alojaria 4 a 9 habitantes e as unidades F1a e F1c, cada uma apenas com uma casa redonda (mas com espaço para ulteriores construções), não albergariam senão casais sem filhos ou com filhos pequenos.

Aceitando a sugestão de Armando Coelho de que F1a a F1d provavelmente corresponde a um "conjunto familiar" (SILVA, 1986: 44, fig. 5), teríamos uma família de 15 a 29 almas, numa área susceptível de futuras construções - isto é, uma família alargada ou indivisa que poderia continuar a crescer. A redução de F1a e F1c a únicas casas redondas que seriam de habitação, sem instalações para armazenamento de grão nem alojamento de gado, sugere que essa família alargada era uma unidade de produção e consumo.

Estes cálculos e estas deduções são, obviamente, muito incertos. E se o conjunto F1a a F1d corresponde efectivamente a uma família alargada, isso obriga-nos a pensar num considerável planeamento, isto é, numa afectação a cada família, na altura da instalação do castro, de uma área suficiente para que a família pudesse crescer e erguer novas construções, mantendo-se espacialmente unida.

Por muito incerto que seja tudo quanto anteriormente dissemos, parece credível a existência de famílias alargadas nos maiores castros do Noroeste. Como seriam designadas tais famílias?

Não temos, no Noroeste, genitivos do plural em -um. Mas temos algumas ocorrências do termo domus. Assim, em Briteiros, na verga de uma porta: Coroneri, Camali domus (CIL II 5595 e CARDOzO, 1972:5). Se bem que domus possa referir-se ao próprio edifício, não é menos credível que o sentido da inscrição seja: De Coronero, da domus de Camalo - com domus no sentido de família alargada.

Uma outra inscrição de Briteiros (CIL II 5590 e CARDOZO, 1972: 
10), onde se lê Camali domi Caturo, poderá entender-se no sentido de "(aqui vive) Caturão, da domus de Camalo"?

Estes exemplos permitem-nos aventar a hipótese de o termo comum usado no Noroeste para designar a família alargada ter sido domus. O determinativo de cada domus seria o nome do sénior da família, isto é, um indivíduo dir-se-ia da domus de um tal, referindo o sénior da família. A morte do sénior e a transferência da senioridade para um seu filho obrigariam a mudar a referência? Ou poderá admitir-se que a referência se mantinha, por uma ou mais gerações, para além da morte do indivíduo que constituía a referência nominal da família? Poderia Coronero continuar a identificar-se como pertencente à domus de Camalo mesmo depois da morte deste último?

O sentido proposto para domus não exclui, noutros contextos, outro(s) sentido(s): o termo seria multi-significante.

É possível que os habitantes de um castellum do Noroeste se designassem a eles mesmos (e fossem conhecidos pelos outros de outros castella) mediante um etnónimo. Recenseando tais nomes, A. Rodríguez Colmenero (1996:154-155) cita, da área de Chaves, os Praeni e os Coroqui, os Obili e os Trebili, os Ripani e os Puanti e outros bem mais incertos. Menciona ainda os Ancondei do castellum Meidunium, que identifica com o castro de Rubiás (Bande).

Para Armando Coelho (1981-1982: 87-88), os Praeni e os Coroqui (ou Coroci?) conviveriam no castro de Lagarelhos ou Castelo de S. Tiago, separados uns dos outros pela muralha mediana que se observa no mesmo povoado. Tal atribuição é, pelo menos, duvidosa, pois essa muralha mediana parece medieval (AMARAL, 1993: 56).

Se Praeni, Coroqui, Obili, etc., eram etnónimos designativos das populações deste e daquele castro, é possível que tais castella não tivessem designativo toponímico próprio e fossem conhecidos como "castellum dos Praeni", "castellum dos Obili", etc. Eventualmente, do etnónimo, mediante o sufixo -(a)iko, poderia ter-se formado um nome. Assim, o castellum dos Praeni poderia ter sido conhecido como castellum Praniaicum.

A tendência (não convincentemente confirmada mas admissível) para a formação de castella maiores poderia ter congregado dois ou mais destes grupos num mesmo povoado, que, neste caso, teria sido designado por topónimo próprio. Assim, se os Ancondei do castellum Meidunium não são uma família alargada, poderiam corresponder a um 
destes supostos grupos que, juntamente com outro(s), se teria instalado no dito castellum. Admitida semelhante hipótese, que nome comum seria dado a tais grupos? Seriam chamados gentilitates, ainda que, para o Noroeste, não tenhamos atestação epigráfica de tal nome?

\section{As gentes}

O termo gens era usado pelos Romanos com múltiplos significados, que vários autores têm analisado (GoNZÁLEZ RoDRíGUEZ, 1986: 86-93; RodríGueZ Álvarez, 1993; RodríGUEZ, 1996).

No âmbito do conventus Asturum, o termo poderá ter sido adoptado para designar unidades "étnicas" similares às que, no conventus Lucensis, Plínio III, 4. 28, designa por populi. Assim como os Callaeci Lucenses integravam várias unidades étnicas (inventariadas por TRANOY, 1981: 53-60) e os Callaeci Bracari compreendiam diversas entidades similares (Leuni, Seurbi, Lubaeni, Nemetati, etc.), os Astures compreenderiam diversos populi, entre os quais Plínio III, 4, 28 cita os Gigurri, Paesici, Lancienses e Zoelae. O nome de gens usar-se-ia como sinónimo de populus e, assim, os Zoelae eram referenciados como gens (CIL II 2633); do mesmo modo, o "bronze de Bembibre" refere-se às gentes Susarrorum e Gigurrorum (GRAU e HOYAS, 2001).

Como noutro lugar sustentámos (AlARCÃO, n. p.), os populi não terão sido, na sequência imediata da conquista, transformados em civitates, mas terão sido reconhecidos como entidades político-administrativas. Os populi do (futuro?) conventus Lucensis terão sido governados por principes indígenas, dos quais há testemunhos epigráficos. Semelhante forma de governo terá sido adoptada para os populi do conventus Bracarum, se bem que não haja, neste, menção epigráfica de principes. As estátuas de guerreiros galaicos representarão, todavia, esses principes (AlARCÃO, n.p.).

Contra esta nossa hipótese, para P. LE Roux (1995: 88), "les structures familiales élargies constituaient les fondements de l'identité des indigènes, une fois que la défaite avait vidé l'ethnie ou la gens de son contenu politique".

Os populi dos Astures terão sido reconhecidos como entidades político-administrativas às quais terá sido dado o nome de gentes. Não sendo prova inequívoca do que propomos, a referência à gens Zoelarum do "pacto de Astorga", CIL II 2633, a menção de Floro II, 33, 52-60 às 
gentes ástures e ao seu concilium, que devia reunir-se num acampamento romano (o de Asturica Augusta, possivelmente, embora não tenhamos prova do estabelecimento de tropas aqui antes de 15/10 a.C., vid. FernándeZ OCHOA e Morillo CERDÁN, 1999: 40) e a designação de gentes para os Sussarri e os Gigurri no "bronze de Bembibre", datado de 15 a.C., são perfeitamente compatíveis com a nossa hipótese.

Alguns eventuais argumentos contrario sensu (criação de falsas "etnias" pelos Romanos, não coincidentes com "identidades" que as populações pré-romanas poderiam sentir, uso muito antigo do termo civitas em vez de gens ou populus) foram por nós considerados, ainda que sumariamente, noutro lugar (AlARCÃO, n. p.), e não nos parece oportuno retomar aqui o assunto.

Para os populi ou gentes ástures, poderão ter sido escolhidos ou designados governantes com o título de magistri, título que no "pacto de Astorga" se regista; mas a documentação é, pelo menos por enquanto, insuficiente para podermos definir o estatuto e função de tais magistri ou magistrati no contexto ásture pré-flaviano.

A transformação dos (ou da maioria dos) populi do Noroeste e Norte peninsulares em civitates terá ocorrido, pelo mais tardar, na sequência imediata da concessão do ius Latii em 73-74 d.C. A gens Zoelarum de $27 \mathrm{~d}$. C. (data da primeira parte do pacto de Astorga), por exemplo, ter-se-á transformado na civitas Zoelarum, pois, não havendo atestação epigráfica directa do nome civitas para os Zoelae, a ordo Zoelarum referida em CIL II 2606 e a expressão civi Zelae (em DIEGO SANTOS, 1986, n. ${ }^{\circ}$ 147) são testemunho bastante desse estatuto de civitas.

$\mathrm{Se}$, como parece dever concluir-se do "pacto de Astorga", o termo gens teve o sentido de unidade político-administrativa (possivelmente coincidente com unidade étnica pré-romana) e se, como sugerimos, os Romanos reconheceram, desde o momento imediato à conquista, várias unidades político-administrativas às quais deram o nome de gentes, é óbvio que gens teve também outro(s) sentido(s), como adiante veremos.

\section{As gentilitates}

O termo gentilitas, em todo o Norte peninsular, ocorre apenas na primeira parte do "pacto de Astorga", que reproduz um acordo celebrado (ou confirmado) em 27 d. C. O mesmo termo surge, porém, numa inscrição de Oliva (Cáceres), consagrada $D($ is) Laribus Gapeticorum 
gentilitatis (CIL II 804; GonZÁlEZ RodríGuEZ, 1986, C. 124; HuRTAdO DE SAN ANTÓNIO, 1977: 184, n. ${ }^{\circ} 389$, considerando que a inscrição procede de Cáparra).

Parece difícil aceitar que, na inscrição de Cáceres, num contexto sociopolítico provavelmente muito diferente do dos Zoelae em 27 d.C., o termo gentilitas tenha o mesmo sentido que no "pacto de Astorga".

A falta de menção do(s) dedicante(s) na ara de Oliva poderá explicar-se por se ter considerado redundante tal explicitação: uma ara aos Lares da gentilitas Gapeticorum não podia ser consagrada senão, colectivamente, pela própria gentilitas Gapeticorum (ou pelo seu sénior, em nome da gentilitas). Mais estranha é a presença de uma gentilitas na área da civitas de Capara. Ficava esta na província da Lusitânia, onde não há, até agora, outro testemunho epigráfico de gentilitas.

A ausência, na Península Ibérica, de um eventual gentilício Gapeticus ou Gapetus parece, à primeira vista, excluir a hipótese de, neste caso, o termo gentilitas designar uma gens, no sentido de uma família e não de uma "unidade étnica". A existência de um nome Cape[...] em moedas de Bilbilis (BURNETT, AMANDRY e RiPOLLÉs, n. ${ }^{\circ}$ 397), tendo em atenção a frequente ocorrência do $\mathrm{C}$ pelo $\mathrm{G}$, ou vice-versa, poderá todavia sustentar essa hipótese de estarmos em presença de uma gens naquele sentido de família (embora, naquela emissão monetária, o nome seja cognomen e não gentilício). Não podemos também deixar de recordar a sugestão de Untermann (1965: 90) de que Gapeticorum pode corresponder a um antropónimo indígena que terá sido substituído pelo muito comum Capito, este, aliás, frequente na actual província de Cáceres. Assim, gentilitas Gapeticorum seria equivalente a gens Gapeticorum. A gens dos Gapetici seria similar à gens Iuliorum e à gens Sex. Aponi Scaevi de Bobadela (CIL II 396).

Poderá não ser totalmente rejeitável, se bem que se nos afigura duvidosa, a hipótese de a ara de Oliva ter sido consagrada por um imigrante, vindo de território ásture. Mas, neste caso, não seria natural que o imigrante, eventualmente vindo com a sua família, se tivesse identificado como procedente de tal ou tal civitas? Neste exercício interpretativo, podemos todavia argumentar que o dedicante, colocando a ara no seu larário doméstico, não sentiu necessidade de indicar a origo da sua família.

Seja como for, este exemplo de Oliva não permite sustentar de forma convincente a hipótese da existência, na região de Cáceres, de "unidades organizativas" similares às que, entre os Zoelae, se designam pelo termo de gentilitates. 
Por outro lado, é duvidoso que, entre os Zoelae (um dos populi / uma das civitates do conventus Asturum), existisse um tipo de unidade organizativa específica dos mesmos Zoelae e que se não observasse em nenhum dos outros populi ástures. Assim, parece oportuno perguntarmo-nos se o termo gentilitas não designa, na primeira parte do "pacto de Astorga", um tipo de unidade organizativa que, no âmbito do conventus Asturum, recebe, noutras epígrafes, outro(s) nome(s).

$\mathrm{O}$ "pacto de "Astorga", referindo-se, na sua primeira parte, à gentilitas Desoncorum ex gente Zoelarum e à gentilitas Tridiavorum ex gente Zoelarum, torna inequívoca a existência, no âmbito da gens Zoelarum, de unidades menores designadas pelo termo gentilitas.

$\mathrm{Na}$ segunda parte do pacto, correspondente a uma renovação e a um alargamento do acordo, celebrados em 152 d.C., os mesmos Desonci e Tridiavi, ainda designados como gentilitates, recebem na sua clientela três indivíduos, um deles procedente da gens Avolgigorum (dos Orniaci, que, nessa data, constituiriam uma outra civitas do conventus Asturum) e dois outros oriundos da gens Visaligorum e da gens Cabruagenigorum, estas pertencentes aos Zoelae.

Um dos grandes problemas suscitados pelo "pacto de Astorga" reside em saber se as entidades aí designadas por gentes são do mesmo tipo das que, no mesmo pacto, recebem o nome de gentilitates. Sem podermos provar que Avolgici, Visaligi e Cabruagenigi são entidades do mesmo tipo dos Desonci e Tridiavi, vamos aceitar que o sejam, como, aliás, sustentou F. Beltrán (1994:90), e apesar de opiniões discordantes, como a de Santos Yanguas (1985:13).

Em 27 a.C., ao celebrar-se o pacto, que, aliás, renovou hospitium vetustum antiquom, os Zoelae eram designados por gens, nome que, de acordo com a proposta apresentada no apartado anterior, se aplicaria também aos outros populi dos Ástures. Em 152 d.C., na data da renegociação do pacto, os Zoelae, como os outros populi ástures, estavam convertidos em civitates. Não sendo já os Zoelae (e os outros Ástures) designados pelo termo gens, mas pelo termo, agora propriamente usado, de civitas, o primeiro destes nomes (gens) estaria disponível para outro uso: terão passado a chamar-se gentes as entidades que anteriormente eram designadas pelo nome de gentilitates. Mas, na segunda parte do pacto, isto é, no acrescento de 152 d.C., não foi, para os Desonci e Tridiavi, actualizada a nomenclatura, e Desonci e Tridiavi foram ainda referidos pelo antigo nome de gentilitates, que constava do documento escrito de 27 d.C., tido presente pelo notário de 152 d.C. 
Esta nossa proposta é uma alternativa à de Juan Santos Yanguas (1985: 9-13). Segundo este autor, a gens dos Zoelae integraria inicialmente diversas gentilitates: Desonci, Tridiavi, Visaligi, Cabruagenigi (e, eventualmente, ainda outras). Os Visaligi e os Cabruagenigi teriam posteriormente adquirido autonomia em relação à gens dos Zoelae e teriam passado a constituir gentes independentes (ainda antes das guerras de Augusto contra Cântabros e Ástures?). Mais tarde ainda, aquando da reorganização político-administrativa (de Augusto? posterior?), a gens dos Zoelae (com Desonci e Tridiavi) teria sido integrada, juntamente com as gentes dos Visaligi e Cabruagenigi, numa unidade ( lus? civitas?) que teria sido designada pelo nome de Zoelae, por ser esta a gens mais importante (ou, eventualmente, por se ter conservado memória de que Visaligi e Cabruagenigi haviam sido, inicialmente, simples gentilitates dos Zoelae). A sugestão de J. Santos Yanguas parece apoiada por M‥ Cruz González Rodríguez (1997: 73, nota 182).

A apreciação destas propostas vai obrigar-nos a um longo desvio, ao longo do qual, todavia, não perderemos de vista o problema principal: o que era uma gentilitas?

O "pacto de Astorga" foi celebrado, em 27 d.C., em Curunda. Não tendo sido possível, até agora, localizar esta povoação, muitos autores admitem que era, ao tempo, o lugar central dos Zoelae. A ocorrência do antropónimo Curunda em Madridanos (Zamora) (Alonso Ávila e ORTíz DE ZARATE, 2000: 45, n. $\left.{ }^{\circ} 75\right)$ não permite apontar uma localização provável para a povoação do mesmo nome.

A hipótese de Curunda ter sido lugar central dos Zoelae assenta apenas no pressuposto de que tal pacto deve ter sido celebrado num lugar importante. Sendo sensata tal hipótese, até pelo facto de o mesmo pacto ter sido renovado e ampliado, em 152 d.C., na capital do conventus, Asturica Augusta, a verdade é que a centralidade de Curunda é apenas uma hipótese e não se acha demonstrada. Parece-nos, pois, legítimo considerar outras hipóteses.

Não tendo quaisquer indícios de que Curunda tenha sido um acampamento militar (ainda que tal hipótese não deva ser liminarmente afastada), discorreremos sobre a capital dos Zoelae.

Tal capital parece ter sido Castro de Avelãs, a curta distância da actual cidade de Bragança. No lugar apenas se fizeram pequenas escavações nos finais do séc. XIX, escavações aliás mal relatadas e insuficientes para se determinar, de forma inequívoca, que se trata de um 
núcleo urbano com alguma importância (LEMOS, 1993, Ib: 386 e IIa: 64). Mas o achado, aí, da inscrição CIL II 2606, consagrada ao deus Aernus pela ordo Zoelarum, é um argumento de muito peso a favor da identificação de Castro de Avelãs como capital dos Zoelae.

O nome de Castro de Avelãs na época romana é desconhecido. A hipótese de corresponder à mansio de Roboretum do Itinerário de Antonino é muito atendível (Lemos, 1993, Ib: 293). Não se nos afigura, porém, impossível que a via de Bracara Augusta a Asturica Augusta, por Aquae Flaviae, passando por Vinhais, se dirigisse a Cova da Lua (Espinhosela, Bragança). De Vinhais (ou das suas imediações), onde haveria uma mansio não referida no Itinerário de Antonino, sairia um ramal para Castro de Avelãs.

Um miliário de Castro de Avelãs, CIL II 6215, onde se tem lido CL ou CLX $[X X]$ milhas, foi recentemente objecto de atento exame por Armando Redentor (2000:161), que pretende deverem ler-se XIX milhas. Ora esta é a distância de Castro de Avelãs a Vinhais, isto é, à nossa suposta encruzilhada. A confirmar-se a leitura de XIX milhas, deveríamos restituir $\mathrm{XX}[\mathrm{IX}]$ ou $\mathrm{XX}[\mathrm{X}]$ nos miliários de Babe ( a oriente de Castro de Avelãs) (EE IX 416; REDENTOR, 2000: 162 e 164)

A ser assim, a capital dos Zoelae em Castro de Avelãs não estaria mencionada no Itinerário da Antonino por não passar por aquela cidade a via de Braga a Astorga. Mas que nome teria, na época romana, a capital dos Zoelae?

No Liber Fidei da Sé de Braga (CosTA, 1965-1990) acham-se, com os n. ${ }^{\circ}$ s 21 e 619, duas cópias de um mesmo original, correspondendo este a um acordo entre os bispos de Braga e Orense sobre a jurisdição do território de Baroncelli, que ambos reivindicavam. D. Afonso VI reuniu, em 1078, árbitros num opido nominato Froila (no doc. n. ${ }^{\circ} 21$ ) ou Troila (no doc. n. ${ }^{\circ} 619$ ). Os árbitros recordaram a divisio Theodimiri, isto é, a lista das dioceses e paróquias também conhecida pelo nome de Parochiale suévico (DAVID, 1947).

Diz-se nos documentos do Liber Fidei, e a propósito da divisio Theodimiri, "ubi scriptum est Cotis et ibi invenitur omne ruina antiqua sicut Equisis et Vergantia adque alias".

O território em disputa situava-se na área de Verín e o opido Troila poderá corresponder a Tróia, perto de Mairos, a nordeste de Chaves. As ruínas de Vergantia que, em 1078, deviam ser suficientemente importantes para merecerem referência, seriam as de Castro de Avelãs. O nome da cidade seria, pois, Brigantia, deturpado em 1078 em Vergantia. Bri- 
gantia era, aliás, nos fins do século VI, sede de um pagus da diocese bracarense (AlARCÃo, 2001:35). Na Alta Idade Média, abandonada a cidade e instalado um novo centro urbano no sítio da actual Bragança, o topónimo emigrou do velho ao novo local.

Ainda que esta nossa hipótese possa vir a confirmar-se com argumentos mais convincentes, isso não invalida que Curunda possa ter sido, noutro lugar, um povoado importante, e mesmo lugar central dos Zoelae em 27 d.C. Nesse caso, a capital dos Zoelae poderia ter sido posteriormente transferida para Castro de Avelãs.

F. Sande Lemos (1993) demonstrou que, na parte oriental da província de Trás-os-Montes, muitos dos pequenos castros pré-romanos foram abandonados e que novos povoados, em lugares baixos, não muralhados, foram instalados. Num outro trabalho (ALARCÃO, 1999), resumimos, de forma muito sintética, os resultados da investigação de Sande Lemos.

Podemos perguntar-nos agora se Curunda não seria uma dessas aldeias ou vici de fundação romana. Duas gentilitates (ou diversas famílias procedentes de duas gentilitates) teriam sido instaladas em Curunda. Semelhante hipótese parece tornar explicável a segunda parte do pacto, em que Desonci e Tridiavi aceitam, in clientelam, três indivíduos, Semprónio Perpétuo, ex gente Avolgigorum, Orniacus, António Árquio, ex gente Visaligorum, Zoela e Flávio Frontão, ex gente Cabruagenigorum, também Zoela.

Se Desonci e Tridiavi fossem co-residentes na aldeia ou vicus de Curunda, a admissão de três indivíduos ganharia sentido. Se Desonci vivessem num povoado ou numa área, e Tridiavi, noutro sítio ou noutra área, como explicar o acolhimento, por ambas as gentilitates, de três indivíduos (certamente com suas famílias)? Os três indivíduos iriam residir parte do ano entre os Desonci e, noutra parte, entre os Tridiavi? Parece difícil admiti-lo. Ou o acolhimento destes três indivíduos in clientelam, por Desonci e Tridiavi, não teria nada a ver com uma "autorização de residência"?

À nossa hipótese de o "pacto de Astorga" corresponder à instalação de duas gentilitates num povoado de nova fundação não é necessária a ideia de Curunda ser o nome da nova aldeia ou do novo vicus: o pacto poderia ter sido celebrado noutro local.

Visto o pacto a esta luz, os seis indivíduos que egerunt o acordo de 27 d.C. poderiam ser três representantes dos Desonci e outros três dos Tridiavi instalados na nova povoação (como aliás sugere LOMAS, 1994: 
130). Ora ainda nos meados do séc. XX, numa aldeia de vida comunitária, Vilarinho da Furna (não, é certo, em Trás-os-Montes, mas em Terras de Bouro, no distrito de Braga), os vizinhos elegiam um conselho composto por seis membros, Os Seis, tendo à sua frente um sétimo, o Juiz ou Zelador (DiAs, 1981: 86-87). A aldeia tinha cerca de 250 habitantes. Sem pretendermos que Vilarinho da Furna mantinha fossilizada uma organização de origem romana ou mesmo pré-romana, não deixaremos de encontrar, na monografia de Vilarinho da Furna, costumes que nos ajudam a imaginar o que poderia ter sido a vida numa aldeia dos Zoelas na época romana. Igualmente inspiradora é a obra do mesmo autor sobre Rio de Onor, agora uma aldeia transmontana em território possivelmente dos Zoelas (DiAs, 1981 (1).

A hipótese de coexistência de duas gentilitates na mesma aldeia pode constituir um passo no esclarecimento de um problema que, todavia, ainda não resolve: que dimensão teria a gentilitas? que laços uniam os gentiles? simples laços de vizinhança ou de parentesco, eventualmente fictício? seria a gentilitas um clã residencial?

Parece pouco credível a existência, no território dos Zoelae, de aldeias com mais de 250 habitantes. A verdade, porém, é que não temos nenhuma aldeia que tenha sido, sequer, objecto de sondagens arqueológicas. A hipótese, atrás posta, de, numa aldeia, não terem sido instalados todos os membros de duas gentilitates, mas apenas algumas famílias procedentes de duas diferentes gentilitates, não pode ser esquecida.

A hipótese de uma gentilitas corresponder, na época pré-romana, a um castro, tem de ser encarada. E porque os pequenos castros dos Zoelae não parecem ter alojado mais de uma a duas centenas de habitantes, esta seria a dimensão da gentilitas. Mas igualmente credível é a hipótese alternativa, posta por Sande Lemos, de uma gentilitas integrar vários castros (LEMOS, 1993, I A: 241 e 264-265; LEMOS, 1996), correspondendo, assim, a um clã territorial.

$\mathrm{Na}$ hipótese de um castro corresponder a uma gentilitas, poderia não ter topónimo próprio. O castro seria chamado, simplesmente, castellum dos... Desonci, por exemplo. Uma aldeia na qual convivessem duas gentilitates teria de ter topónimo próprio: Curunda, por exemplo.

Talvez, a propósito destas aldeias zoelas, se deva falar de reordenamento territorial e não propriamente de integração política. $M^{a}$. Cruz González Rodríguez (1997: 72) interpreta o pacto de 27 d.C. como um passo no sentido dessa integração política e a renovação de 152 d.C. como um passo mais no mesmo sentido. Mas não esquece a autora que, 
em 152 d.C., são indivíduos que os Desonci e Tridiavi acolhem e que não se trata, então, de um pacto que Desonci e Tridiavi estabeleçam com outras comunidades na sua globalidade?

A nossa hipótese de aldeias onde coexistiam duas gentilitates poderá explicar por que razão não encontramos, nas fórmulas onomásticas das inscrições funerárias da civitas Zoelarum, nenhuma menção de gentilitas. Com efeito, tais inscrições, geralmente, reduzem-se ao nome do sepultado, seguido do nome do pai, do tipo Boutius, Talogi f(ilius), ann(orum) XXXV. S(it) t(ibi) t(erra) l(evis) (de Sacoias, Baçal, Bragança, EE VIII 300 e EE IX 279). Se uma aldeia tivesse dois cemitérios, um para cada gentilitas (eventualmente de um lado e do outro do mesmo caminho de acesso ao povoado), não seria necessário indicar a gentilitas, pois seria óbvio que os deste lado pertenciam a tal gentilitas e os do outro lado, à outra gentilitas. Além disso, a normal falta de dedicante não poderá indicar que os funerais eram organizados, não pelo filho do falecido ou seus parentes mais próximos, mas por toda a sua gentilitas? A gentilitas funcionaria assim como um "grupo de nojo", como, aliás, já noutro lugar sugerimos (ALARCÃo, 1999(1): 142).

Se um membro de uma gentilitas, falecido no povoado onde residia sua gentilitas, poderia, compreensivelmente, não levar indicação da gentilitas a que pertencera, devemos considerar pelo menos como provável a existência de uma norma correlativa: a de se indicar a gentilitas quando alguém emigrava e morria em território de outra gentilitas. Neste caso, a ausência de gentilitates nas inscrições funerárias dos Zoelae obrigar-nos-ia, logicamente, a concluir que, no âmbito deste populus/desta civitas, não houve ninguém que, nascido na área de uma gentilitas, tenha morrido no âmbito territorial doutra gentilitas. Ora, mesmo que as gentilitates fossem unidades endogâmicas (o que dificilmente seriam, se cada gentilitas correspondesse a um pequeno castro), é credível que nenhuma deslocação se tivesse efectuado? Se as gentilitates eram unidades exogâmicas, será que os cônjuges deslocados por via do casamento eram recebidos como membros da gentilitas para a qual transferiam residência? A documentação epigráfica não nos permite, infelizmente, extrair conclusões minimamente aceitáveis. Por outro lado, pode argumentar-se que as inscrições dos Zoelae não são extremamente abundantes e mesmo supor-se que muitas das que existiram se perderam. Eventuais lápides funerárias com indicação de gentilitates podem ter desaparecido. Ou pode ter havido deslocações sem que os deslocados tenham sido sepultados com lápides epigrafadas. Seja como for, 
temos que reconhecer que a ausência de gentilitates na epigrafia funerária dos Zoelae suscita algumas interrogações. Adiante reconsideraremos o problema.

É geralmente atribuída aos Zoelae a inscrição $E E$ VIII $128=E E$ IX 110, encontrada em Aldeia Nova, consagrada a Aemilius Balaesus, signifer alae Sabininiae.

A parte final da inscrição tem sido objecto de múltiplas interpretações. As mais recentes são as de Rodríguez Colmenero (1987: 282-283) e Le Roux (1995: 88-89). Segundo o primeiro, a parte final poderá interpretar-se como cognatio de(dicavit) gent(ili) s(vo). Segundo Le Roux, cognatio Decen[orum], Decen[icorum] ou Decen[icum].

Parecendo mais credível a segunda interpretação, mesmo no caso de se adoptar a primeira (que tem, contra ela, o facto de não se indicar o nome da cognatio), a cognatio seria a dedicante. Ora nesta cognatio não deveremos ver uma unidade similar à gentilitas? Trata-se de "unidades organizativas" diferentes ou de nomes diferentes para o mesmo tipo de "unidade organizativa"?

A correcta integração político-administrativa de Aldeia Nova poderá não fazer grande diferença para o esclarecimento deste problema. Mas não queremos deixar de observar que Aldeia Nova se situava, provavelmente, no âmbito de um outro populus/ uma outra civitas do conventus Asturum: a civitas dos Astiati (AlARCÃo, 2001: 35-36).

A identificação da cognatio de Aldeia Nova como gentilitas, por seu lado, não pode deixar de suscitar a questão: por que motivo um mesmo tipo de "unidade organizativa" era designado por gentilitas e/ou cognatio? O facto de a(s) " unidade(s) organizativas" do conventus Asturum não ter(em) correspondência ou paralelo na sociedade romana obrigaria ao uso impróprio (ou com novo significado) de algum termo latino (a menos que tivesse sido inventado nome novo, o que não foi feito): assim, poderia ter havido hesitação entre gentilitas e cognatio na escolha do nome para designar o grupo social indígena, e os dois nomes poderiam ter sido simultaneamente usados (embora se não entreveja quem poderia usar um e quem preferiria o outro, ou em que contextos ou datas se teriam usado um e outro).

Não considerando impossível que o mesmo tipo de "unidade organizativa" fosse, por uns, designado pelo nome de gentilitas e, por outros, pelo de cognatio, e que este nome comum de cognatio se usasse ainda, noutras áreas, para designar um tipo de "unidade organizativa" 
diferente (como no caso da cognatio Magilancum de Montealegre de Campos, que mais adiante abordaremos), deixaremos aqui a dúvida por incapacidade de encontrarmos uma solução que nos pareça incontroversa.

Analisando o "pacto de Astorga”, inclinamo-nos, pois, para a hipótese de as gentes da segunda parte do pacto serem "unidades organizativas" similares às gentilitates da primeira parte do documento. Haveria assim, no conventus Asturum, um tipo de "unidade organizativa" que poderia ser designado pelo nome de gentilitas ou pelo de gens (e também pelo de cognatio?), não podendo de todo em todo excluir-se que o de gentilitas tenha sido, a partir de certa data, substituído pelo de gens ou que, a partir de certo momento, o de gens tenha passado a ser designação mais corrente que o de gentilitas sem ter inteiramente substituído este último.

Ainda que se não aceite, entre os Ástures, a equivalência gens = gentilitas, parece difícil sustentar a sugestão de Ma․ Cruz González Rodriguez (1997: 77-78): “estas gentes de los astures serán com bastante probabilidad, al igual que las gentes de la segunda parte del pacto de los Zoelas del 152 d.C., la base a partir de la cual los romanos establecen su esquema administrativo y sus células básicas, las civitates... y quizás alguno de sus nombres correspondan y coincidan con los de los populi cuyo nombre no nos ha sido tranmitido ni por Plinio ni por Ptolemeo".

A equivalência gentilitas $=$ gens no interior do conventus Asturum, a ser aceite (pelo menos, como hipótese), levar-nos-ia a identificar, como gentilitates, as gentes Abilicorum, Ablaidacorum, Pentiorum e Ratrium (GonZÁlez RodrígueZ, 1986, C. 3, 6, 160 e 171), bem como a gens Cilurnigorum de Gijón (FERnández OchoA e PÉrez FERnández, 1990), todas da parte nordeste do mesmo conventus, onde, aparentemente, se devem situar os Luggoni (Tranoy, 1981: 49; GonZÁlEZ RoDRÍGUEZ, 1997: 44-45).

A existência do topónimo El Celurno no vale do Uriés, na paróquia de Serrapio do concelho de Aller (FERnández OchOA e PÉREZ FERNÁNDEZ, 1990: 260), não é segura prova de que residisse aí a gens (ou gentilitas) Cilurnigorum; mas também não pode excluir-se inteiramente essa hipótese. Por outro lado, na mesma paróquia temos os Arronidaeci e os Coliacini (DIEGo SANTOS, 1959: n. ${ }^{\circ}$ 1), que poderão, eventualmente, corresponder a gentilitates, como atrás vimos. 
No caso de estas gentes dos Luggoni corresponderem a gentilitates, como explicar, porém, que entre os Luggoni se usasse mencionar a gentilitas na identificação do dedicado das inscrições funerárias e não fosse isso uso dos demais populi ou das demais civitates do conventus?

A complicar ainda mais a interpretação, temos, entre os mesmos Luggoni, epitáfios em que o dedicado ou dedicante é integrado numa "unidade organizativa" cujo nome próprio se indica por um genitivo do plural em -um, como Oilaridu(m) e [O]nnacau(m) (GONZÁlEZ RodRíGUEZ, 1986, C. 159 e 160). A segunda destas inscrições é particularmente difícil de explicar, dado pai e filha pertencerem a "unidades organizativas" não só diferentes como diversamente designadas. Pela sua importância, justifica-se que se transcreva essa inscrição de Cofiño (Parres, Astúrias):

[Monument]um p[ositum] [dib]us Manibus. [Scorcia?] [O]nnacau(m), Ammiae Caelionigae, ex gente Pentioru(m), anno(rum) XV, pater filiae posuit. Do(mino) no(stro) Postumo IIII et Vict(orino) co(n)s(ulibus). (GoNZÁLEZ RoDRÍGUEZ, 1986, C. 160).

O nome do pai, Scorcia, é duvidoso. Mas o dedicante identifica-se como pertencente ao grupo [O]nnacau $(m)$, enquanto a filha, Ammia Caelioniga, é integrada na gens Pentiorum. Esta gens seria uma unidade do mesmo tipo da que leva o nome $[O] \operatorname{nnacau}(m)$ não precedido de $e x$ gente? Se se trata de unidades similares, por que razão uma é precedida de ex gente e outra não? Por outro lado, como explicar que o pai pertença a uma "unidade organizativa" e a filha, a outra? Pertenceria a filha à "unidade" da mãe? E, neste caso, teremos aqui uma reminiscência daquela "espécie de ginecocracia" de que fala Estrabão, III, 4, 18? Ou é apenas um caso em que, sem que se possa falar de ginecocracia, os filhos tomavam o gentilício da mãe e não o do pai, eventualmente por ser a família materna mais ilustre que a do pai? Ainda que nos não pareça inteiramente convincente, não deixaremos de referir a opinião de Mª . Cruz González Rodríguez (1994: 166), para quem Onnacaum seria uma gentilitas e os Pentii, obviamente, uma gens. A inscrição referiria, assim, duas "unidades organizativas" de tipo diferente.

Os genitivos do plural em -um dos Luggoni designam "unidades organizativas" diferentes das gentes dos mesmos Luggoni? Neste caso, 
os Luggoni integrariam diversas gentes e cada gens integraria diversas "unidades" menores designadas por genitivos do plural em -um?

Não nos parecendo esta situação totalmente inviável, não consideramos tal hipótese mais credível que esta outra: entre os Luggoni, como entre os Zoelae, havia "unidades organizativas" que poderiam ser comummente designados pelo termo gens, mas aos quais se podia também fazer menção simplesmente através de um genitivo do plural em -um.

Assim, a lápide Vianeglo, Segei (filio), ex gente Abilicorum (GoNZÁLEZ RodrígUEZ, 1986, C. 3) poderia ter sido gravada Vianeglo, Segei (filio), Abilicum ... Por seu turno, a lápide Aravo, Oilaridu(n), Licin(i) f[il(io)] (GonzÁlez RodRíGuEZ, 1986, C. 159) poderia ter levado a inscrição Aravo, ex gente Oilaridum...

Se não vemos argumentos decisivos para contrariar a hipótese de os genitivos do plural em -um dos Luggoni designarem gentes, nem para desmentir esta outra hipótese de as gentes dos Luggoni corresponderem às gentilitates dos Zoelae, não parece fácil, neste momento, encontrar resposta para esta incómoda pergunta, que temos de repetir: por que razão não temos menção de gentilitates nas fórmulas onomásticas das lápides funerárias dos Zoelae e as encontramnos nas lápides dos Luggoni, que se situavam no mesmo conventus? Será que, afinal, as gentes dos Luggoni eram "unidades organizativas" diferentes das gentilitates dos Zoelae?

Fora do território dos Luggoni, mas no interior do conventus Asturum, genitivos do plural existem também em Asturica Augusta e Legio.

Em Astorga, os genitivos do plural em -um ou -orum estão representados pelas lápides funerárias de Proculus, Tritalicum, L(uci)f(ilius), Uxsamensis e de Alla Verna, Legirnicorum, Brigiacina (GoNZÁLEZ RoDRÍGUEZ, 1986, C. 185 e 128). Trata-se, pois, de imigrantes, o primeiro procedente da civitas de Uxsama (conventus Cluniensis) e a segunda, da civitas de Brigaetium (do conventus Asturum). A indicação da "unidade organizativa" poderia, numa primeira tentativa de interpretação, explicar-se pela necessidade de completa identificação da origem de indivíduos vindos de fora. Mas, tendo em atenção a importância de Asturica Augusta como centro urbano e a probabilidade de ter atraído indivíduos procedentes de muitas gentilitates, por que motivo não temos mais do que aqueles dois testemunhos, dos quais só um corresponde a uma civitas do conventus Asturum?

A explicação poderá eventualmente encontrar-se na desvalorização que sofreria, num meio urbano tão evoluído como o de Asturica 
Augusta, a origem "gentilícia", quer por parte dos imigrantes, quer por parte da população da cidade em geral. Imigrantes esqueceriam suas gentilitates ou gentes para recordarem apenas sua civitas de origem. Os casos de Allia Verna e de Proculus seriam excepções. Aliás, podemos duvidar se a unidade Legirnicorum seria do mesmo tipo da uxamense Trilalicum. Não teremos, no primeiro caso, uma gentilitas do tipo das dos Zoelae e, no segundo, uma cognatio do género da dos Magilancum de Montealegre de Campos (sobre a qual nos pronunciaremos adiante)?

Em Legio, o genitivo do plural Caibaliq(um) aplica-se também a uma Uxsamensis, mas o genitivo [O]rbienicum identifica um Licinius que não leva outra indicação de origo (GONZÁLEZ RoDRíGUEZ, 1986, C. 72 e 161). Deveremos tomar [O]rbienicum como nome de uma gens ou gentilitas de Legio?

Ainda no conventus Asturum, uma inscrição, mas votiva, achada em Vigo de Sanábria, contém um genitivo do plural: Madarssu [...] Blacau Burrilus, Avelci f(ilius), exs gente Arnicio[r]um exs v[oto] (Alonso Ávila e Ortíz de Zarate, 2000: 93, n. ${ }^{\circ}$ 202).

Feita esta revisão das epígrafes do conventus Asturum com menção de "unidades organizativas", parece impor-se a singularidade atrás afirmada, e não facilmente explicável, dos Luggoni.

$\mathrm{O}$ autor de um discurso histórico deve ser vigilante de si mesmo. Por outras palavras, mais claras, nós mesmos, pretendendo analisar e reconstituir a natureza das "unidades organizativas" indígenas do Norte e do Noroeste, devemos distinguir os dados, dos factos que deduzimos dos dados e devemos verificar o que é que, no nosso discurso, é apenas um pressuposto, ou qual é a razoabilidade do pressuposto (sobre estes conceitos, AlARCÃo, 2000: 172-176).

A estranheza que nos causa a frequência das "unidades organizativas" nas fórmulas onomásticas da epigrafia funerária dos Lugonni, comparada com a quase total ausência dessas unidades nas lápides funerárias do resto do mesmo conventus, assenta, afinal, num simples pressuposto: que, no interior de um mesmo conventus, não só se deveria encontrar identidade de organização social, como uniformidade na menção (ou ausência dela) dessas unidades nas fórmulas onomásticas da epigrafia funerária. É também um simples pressuposto (o qual, como acabou de verificar-se, não adoptamos) considerar que os genitivos do plural em -um devem designar "unidades organizativas" de tipo diferente das gentes ou que o termo gens deve designar "unidades organizativas" de tipo diverso das gentilitates. 
Já Ma․ Cruz Gonzáles Rodríguez (1997: 73, 77 e 91-92) chamou a atenção para a aparente diversidade e complexidade do território definido pelos Romanos como conventus Asturum. Mas parece-nos que essa diversidade carece de explicação. Não pretendemos tê-la encontrado, mas não deixaremos de apresentar algumas propostas.

Regressamos a nossa hipótese de as gentes da segunda parte do "pacto de Astorga" serem unidades idênticas às que, na primeira parte do mesmo documento, se designam por gentilitates. A ideia de gentilitas=gens não parece merecer a aprovação de M⿳a . Cruz González Rodríguez, que diz: "la equivalência que se hacía entre gentilitates=ex gente, a excepción de ex gente Zoelarum = genitivos de plural como términos con igual contenido y utilizados para designar una misma realidad, en la mayoría de los autores = clan, no puede seguir considerándose como válida" (1986:84).

Haverá, porém, suficientes argumentos para negar a identificação de gentilitas = gens? (Admita-se, obviamente, que gens, termo equívoco, tinha também o sentido de populus, como no caso de gens Zoelarum). Se a gentilitas corresponde a uma "unidade organizativa" de tipo diferente da gens, teremos de considerá-la específica dos Zoelae, pois não é seguro que a gentilitas Gapeticorum de Cáceres, CIL II 804, seja unidade do mesmo tipo. Por que razão, repetimos, haveriam os Zoelae de ter uma "unidade organizativa" sem paralelo em nenhum outro populus ou outra civitas do Norte da Península Ibérica? Por que motivo não encontramos gentilitates, por exemplo, na área em torno de Asturica Augusta?

O povoamento desta área apresenta consideráveis diferenças relativamente ao da dos Zoelae, quer na época pré-romana, quer sob o domínio romano.

Foi tal povoamento objecto de aturado estudo por Almudena Orejas (Orejas Saco Del Valle, 1996). Junto da confluência do rio Tuerto com o Orbigo situam-se três castros de consideráveis dimensões (CND 30, 32 e 67), com 18, 6,5 e 7,5 hectares. Os dois primeiros poderiam ter populações superiores a 1400 e 1000 habitantes, respectivamente. O castro CND 67, apesar da sua área considerável, não teria mais de 250 habitantes, dado que uma grande parte da superfície intramuros não era habitável.

Para ocidente observam-se seis outros castros. Se dois deles têm ainda cerca de 5 hectares (CND 28 e 65), não teriam populações supe- 
riores a 400 e 250 habitantes, respectivamente (dado que também não seriam habitáveis grandes áreas). Os outros quatro povoados (CND 31, 39, 48 e 19) teriam populações inferiores a 250 habitantes.

As distâncias a que se encontram, uns dos outros, estes castros a ocidente do rio Orbigo oscilam entre 9 e 13 quilómetros e as respectivas visibilidades (ou invisibilidades) estão representadas na fig. 18 de Almudena Orejas. Tendo em atenção as distâncias, acessibilidades e intervisibilidades neste conjunto de castros, a hipótese de integrarem uma ou duas gentilitates não parece muito credível. Não deveremos antes considerar a hipótese de, a cada um dos pequenos castros, corresponder uma gentilitas? E de, nos grandes castros (eventualmente de formação tardia), conviverem duas ou mais gentilitates, como no caso, atrás considerado, de Serrapio? Ou de, nos grandes castros, haver famílias alargadas mas não gentilitates, como no caso do Noroeste anteriormente considerado no nosso apartado 6 ?

Pode surpreender que, a terem existido gentilitates nesta área, na $2^{\text {a }}$ Idade do Ferro, se não encontrem epigraficamente documentadas na época romana. Mas não devemos esquecer que a área em torno de Astorga examinada por Almudena Orejas sofreu, com a instalação dos Romanos e a intensificação da exploração aurífera, transformações de povoamento e sócio-económicas que podem ter desarticulado a organização social indígena. Tal organização, com as suas gentilitates, poderia ter-se conservado no território dos Zoelae, que não sofreu as profundas transformações da área asturicense examinada por Almudena Orejas, isto é, a área do mons Tillenus e das bacias dos rios Duerna e Turienzo.

Se as transformações que esta última área sofreu podem explicar a ausência de gentilitates, terão elas desaparecido em todo o resto do conventus Asturum? Não será uma gentilitas a gens Arniciorum de Vigo de Sanábria (Alonso ÁvilA e OrTíz DE ZÁrATE, 2000: 93, n. 202)? Não será uma gentilitas a "unidade organizativa" dos Brigiacini designada pelo genitivo do plural Legirnicorum (GoNZÁLEZ RodRíGUEZ, 1986: C 128)?

Se considerarmos a hipótese de equivalência gentilitas $=$ gens, teremos multiplicado os casos de atestação deste tipo de "unidade organizativa" no âmbito do conventus Asturum: não só teríamos Desonci e Tridiavi entre os Zoelae, como, no mesmo populus, Visaligi e Cabruagenigi; entre os Orniaci, a gens = gentilitas dos Avolgigi (citada no mesmo "pacto de Astorga"); em Vigo de Sanabria (Zamora), a gens 
Arniciorum; entre os Luggoni, as gentes Abilicorum, Ablaidacorum, Pentiorum e Ratrium (GonZÁlez RodRíGueZ, 1986, C. 3, 6, 160 e 171).

Não poderemos ainda ir mais longe, e sustentar que os genitivos do plural em -um e em -orum, não precedidos de ex gente, que se testemunham no âmbito do conventus Asturum, correspondem ainda ao mesmo tipo de "unidade organizativa", isto é, correspondem a gentilitates $=$ gentes?

A adopção, no mesmo conventus e em todos os lugares e contextos, de uma mesma fórmula, isto é, de um único e mesmo modo de indicar o mesmo tipo de "unidade organizativa", seria, obviamente, mais "lógica". Mas pretender que diferentes "fórmulas" correspondem necessariamente a diferentes tipos de "unidades organizativas" não será apenas um pressuposto nominalista? E diferentes "fórmulas" para designar o mesmo tipo de "unidade organizativa" não se coadunam, aliás, com a pretendida diversidade que se observa no mesmo conventus? A sustentar essa diversidade, poderemos ainda referir a presença, na parte actualmente portuguesa do conventus, dos berrões ou verracos típicos dos Vettones (ÁlvareZ-SANCHís, 1999: 215 s.) ou do culto de Bande, divindade caracteristicamente galaico-lusitana (PRÓSPER, 2002: 275 s. e mapa da p. 512).

A hipótese de as gentilitates, as gentes e os genitivos do plural do conventus Asturum corresponderem a um único e mesmo tipo de "unidade organizativa" não significa, necessariamente, que todos os genitivos do plural, em qualquer parte da Península Ibérica, designem "unidade organizativa" similar. Poderia haver um mundo de gentilitates e um mundo diferente de cognationes, que seriam unidades de outro tipo, sobre as quais adiante nos pronunciaremos. Simplesmente, quer no caso das gentilitates, quer no das cognationes, o nomen poderia ser indicado por um genitivo do plural em -um ou -orum, não precedido de gens ou cognatio.

Mas reincideremos no que, à partida, não tem explicação fácil: se, no conventus Asturum, os nomes gentilitas e gens designam um mesmo e único tipo de "unidade organizativa", a qual pode ainda, nas fórmulas onomásticas das inscrições funerárias, vir expressa por um genitivo do plural sem que este venha precedido de ex gente, por que razão só entre os Luggoni se indica, para os dedicados e/ou dedicantes, a "unidade organizativa" a que pertencem? Por que motivo, entre os Zoelae do mesmo conventus, a fórmula onomástica contém o nome do pai, mas nunca o da "unidade organizativa" do dedicado? 
Sem podermos dar uma resposta satisfatória ou inteiramente convincente ao problema da natureza das gentilitates, mas manifestando a nossa concordância com Mª . Cruz González Rodríguez quando propõe que a gentilitas era um grupo definido não só por uma suposta consanguinidade como por um vínculo territorial (1997: 81-82 e 88; 1998: 339), consideraremos dificilmente sustentável, como já dissemos, a opinião da mesma autora (1998: 334) quando afirma que as gentes "são a base a partir da qual os Romanos estabelecem as suas células político-administrativas básicas, as civitates" (vid. também GoNZÁLEZ RoDRíGUEZ, 1997: 77-78). Ou, mais do que dificilmente sustentável, consideramos equívoco o trecho citado. Com efeito, o que nos parece necessário é distinguir dois sentidos do termo gens, termo polivalente, como também o considera P. Le Roux (1995: 89). Num sentido, o termo corresponde a uma "unidade étnica" que, efectivamente, serviu de base à civitas: a gens Zoelarum deu origem à civitas Zoelarum. Noutro sentido, gens designa uma "unidade organizativa" inferior à "unidade étnica”, populus ou civitas. O Sempronius Perpetuus recebido por Desonci e Tridiavi em 152 d.C., é dito ex gente Avolgigorum, Orniacus. Dado que os Orniaci constituíam uma civitas do conventus Asturum (Tranoy, 1981: 49-50), a gens Avolgigorum deve, forçosamente, entender-se como entidade menor integrante dessa civitas. Por outro lado, nada permite sustentar que as gentes Abilicorum, Ablaidacorum e Ratrium, anteriormente referidas, correspondem a civitates (ou a populi posteriormente convertidos em civitates): pelo contrário, a sua localização geográfica inclina-nos a tomá-las como unidades integrantes do populus/da civitas dos Luggoni.

Admitamos, em conclusão, que a gentilitas era uma "unidade organizativa" identificável com a população de um castro (ou de um conjunto de pequenos castros) e que, na época romana (se não já desde o final da $2^{\mathrm{a}}$ Idade do Ferro, pré-romana), duas ou mais gentilitates, frequentemente (ou em algumas ocasiões), se congregaram num mesmo povoado (castellum maior, aldeia ou vicus). Evitamos o termo clã apenas por ignorarmos se os membros dessa unidade social se consideravam descendentes de um (mítico) antepassado comum; mas, evitando o termo, não nos pronunciaremos contra a possibilidade de as gentilitates corresponderem efectivamente a clãs.

A ausência da menção das gentilitates na epigrafia funerária do conventus Asturum (com excepção dos Luggoni e da Brigiacina 
atrás referida) poderá explicar-se pela organização das necrópoles (como anteriormente sugerimos).

Quando, num castellum, vicus ou aldeia onde residia(m) uma ou duas gentilitates se vinha estabelecer um indivíduo ou uma família procedente doutra gentilitas, o(s) imigrante(s) poderiam "esquecer" a gentilitas de origem, sendo esse esquecimento um meio de garantir melhor integração social no "nós" da povoação. A memória ou invocação de origem diferente seria nociva a tal integração.

Se, em termos de estratégia pessoal ou familiar de integração, a ausência da gentilitas do(s) imigrante(s) se pode entender, fica-nos todavia sempre o mesmo problema: por que razão se mencionam as gentilitates entre os Luggoni? A pergunta que fazemos implica, obviamente, como pressuposto, a hipótese que temos vindo a considerar, isto é, a de as gentes dos Luggoni serem "unidades organizativas" idênticas às gentilitates dos Zoelae.

Não teremos, porém, de considerar, desmentindo a nossa anterior hipótese, que as gentes dos Luggoni e as "unidades organizativas" designadas por genitivos do plural em -um ou -orum presentes no território dos mesmos Luggoni não são, afinal, gentilitates e se aproximam das "unidades organizativas" dos Vadinienses com os quais os Luggoni confinavam? Para examinar esta nova hipótese, devemos aguardar a análise das "unidades organizativas" dos Vadinienses, que faremos no apartado 10 deste nosso estudo.

\section{As "unidades organizativas" designadas por genitivos do plural em -um}

São frequentes, na área dos Arévacos, Berones, Pelendones e Celtiberos Citeriores (Belos, Titos e Lusones), bem como na dos Vetões, as inscrições funerárias que mencionam "unidades organizativas" designadas por genitivos do plural em -um/-un ou -om/-on. A partir da téssera de Montealegre, onde o genitivo Magilancum é precedido pelo termo cognatio, tem-se aceite que tais unidades eram designadas por este nome de cognationes. 


\subsection{A téssera de Montealegre}

A téssera foi achada em 1985 na localidade de Montealegre de Campos, na província de Valladolid. O local, em território dos antigos Vaqueus, corresponde a um castro de consideráveis dimensões e com romanização intensa. (TIR, Hoja K-30: Madrid).

O texto da téssera é o seguinte:

\section{Iulio Vrso Serviano III Publio}

Vivio Varo cos. V nonas octobres (sic)

Granius Silo et Aemilius Sapienus et

Iulius Proculus tesseram hospita-

lem pro meritis Elaesi Ottae Aii

filii nomine cognationis Magi-

lancum Amallobrigenses Cab-

rumuria et Paligo renovarunt

cum senatu populoque Caucen-

sium in perpetuum sibi liberis

posterisque omnibus eorum

per legatos

M. Valerium Lentulum IIvirum

et Lucium Sempronium Quadratum

O texto tem sido objecto de ampla discussão, que não pretendemos aqui resumir. Mas confrontaremos as traduções de $\mathbf{M}^{\mathbf{a}}$. de Lurdes Albertos (in Balil Illana e Martín Valls, 1988) e G. Pereira Menaut (1993), que representam opostos entendimentos de um trecho essencial da téssera, entendimentos entre os quais se dividem os muitos investigadores que se têm ocupado do documento (para além dos citados, entre outros: GoNZÁlez RodRíGueZ, 1997: 84 s.; LE RouX, 1995: 91; MAÑANES e SOLANA, 1999: 49-62):

Mª . LuRdes AlBertos: Grânio Silão e Emílio Sapieno e Júlio Próculo, de uma parte, em atenção aos serviços de Eleso Ota, filho de Aio (e) em representação da cognatio dos Magilancos, os Amalobrigenses Cabrumúria e Paligão renovaram o pacto de hospitalidade com o senado e o povo dos Caucenses.

G. Pereira Menaut: Grânio Silão e Emílio Sapieno e Júlio Próculo renovaram um pacto de hospitalidade em virtude dos ser- 
viços de Eleso Ota, filho de Aio, em nome da cognatio dos Magilancos Amalobrigenses de Cabrumúria e de Paligo, com o senado e o povo dos Caucenses.

Como se vê, a diferença essencial reside no entendimento de Cabrumuria e Paligo, que M⿳亠丷厂 . Lurdes Albertos toma como antropónimos e G. Pereira Menaut, como topónimos. A dúvida que divide os investigadores (cfr. BELTRÁN, 1994: 90, nota 87), resulta de não haver nenhum testemunho literário ou epigráfico independente que nos esclareça se Cabrumuria e Paligo são antropónimos ou topónimos.

Não parece haver dúvidas quanto ao sujeito de renovarunt: foram Grânio Silão, Emílio Sapieno e Júlio Próculo que renovaram o pacto com o senado e o povo de Cauca. Na opinião de Mª . Lurdes Albertos (in BALIL IllanA e MARTín VAlls, 1988: 23), estes três indivíduos terão representado o senado e o povo de Cauca. Parece difícil admiti-lo, não só por falta de identificação de Grânio Silão, Emílio Sapieno e Júlio Próculo como caucenses, mas porque parece mais verosímil que, por parte de Cauca, tenham actuado o duúnviro M. Valério Lentulo e o legado Lúcio Semprónio Quadrado. A ser assim, terão os três indivíduos referidos representado a cognatio dos Magilanci? O facto de não terem qualquer nome comum não é impeditivo da sua pertença a uma mesma "unidade organizativa" correspondente a uma família de considerável extensão lateral, como representaremos na fig. 3 .

Ora, sendo M. Valério Lentulo duúnviro da cidade de Cauca, se o acto jurídico da renovação do pacto se tivesse efectuado nesta cidade, não haveria motivo para que tivesse sido designado um legatus para acompanhar o duúnviro. Se, pelo contrário, o duúnviro se deslocou a Montealegre de Campos, a ordo decurionum caucense, não querendo que os dois duúnviros se ausentassem da cidade ao mesmo tempo (o que, aliás, seria ilegal), teria nomeado um outro decurião para acompanhar o duúnviro. Esse decurião não teria outro título senão o de legatus. M. Valério Lentulo poderá até ter nomeado um praefectus pro IIviro para o substituir na sua ausência, sobretudo no caso de a sua saída se não ter reduzido a uma ida e vinda a (e de) Montealegre de Campos mas ter sido mais longa, para tratamento de outros assuntos, eventualmente noutros lugares. Isto, porém, é irrelevante para a análise do texto da téssera.

A expressão pro meritis suscita algumas dúvidas: tanto pode entender-se no sentido de "pelas qualidades" como se lhe pode atribuir o sentido de "pelos serviços". 
A expressão (in) nomine cognatio Magilancum obriga-nos a pôr a pergunta: afinal, quem é que actuou em nome da cognatio dos Magilancos? É admissível que tenham sido Cabrumuria e Paligo (e, neste caso, estes nomes corresponderiam a antropónimos). Não parece menos aceitável que tenham sido Grânio Silão, Emílio Sapieno e Júlio Próculo. Muito dificilmente aceitaremos que tenham sido estes três indivíduos e, ao mesmo tempo, também Cabrumúria e Paligão. Mas uma outra interpretação nos parece defensável: que Eleso Ota tenha prestado alguns serviços em nome e representação da cognatio Magilancum, da qual esse Eleso Ota seria membro, sénior ou chefe. Nesse caso, a quem teriam sido prestados os serviços? Seria Eleso Ota um caucense que prestou serviços aos habitantes da povoação romana do actual sítio de Montealegre de Campos? Ou, pelo contrário, a cognatio dos Magilancos residiria em Montealegre de Campos e os serviços teriam sido prestados ao povo de Cauca?

Deixando, por momentos, a questão em aberto, perguntar-nos-emos se Cabrumuria e Paligo devem, afinal, interpretar-se como antropónimos ou topónimos.

A interpretação como topónimos não é fácil de aceitar, pois, nesse caso, aos nomes deviam ter sido acrescentadas desinências casuais que inequivocamente os situassem, no texto, como genitivos de origem. Deveríamos ter, pois, Cabrumuriae et Paligone (no caso de Paligo corresponder a um tema em -n-, isto é, de flexão atemática, Paligōo-ōnis). Em alternativa, Cabrumuria e Paligo deveriam ser precedidos da expressão ex vico ou de vico, ou ex castello ou de castello. A hipótese de Cabrumuria e Paligo serem topónimos em ablativo não precedido de preposição (PEREIRA Menaut, 1993: 413) também se não pode descartar-se o topónimo fosse Paligum. Em tais casos, deveríamos entender que os membros do cognatio Magilancum viviam repartidos por duas diferentes localidades: Cabrumuria e Paligo.

Se Cabrumuria e Paligo fossem topónimos, teríamos aqui dois vici ou castella que deveriam depender de uma capital de civitas. Amallobriga seria, então, essa capital. Ora, não sendo esta hipótese impensável (tendo sido adoptada por LE RouX, 1995: 91), não temos prova de capitalidade de Amallobriga. Parece-nos que devemos excluir, por muito pouco credível, a hipótese de Cabrumuria e Paligo corresponderem a duas localidades dependentes de uma terceira, Amallobriga, que, por sua vez, dependeria de uma cidade com estatuto de capital de civitas. 
Perante tantas dúvidas sobre a natureza de antropónimos ou topónimos de Cabrumuria e Paligo, a interpretação de J. Velaza Frías (1989), apesar de, aparentemente não ter tido eco e aceitação, poderá ser a mais correcta. O pacto de Montealegre de Campos, por se tratar de uma renovação, feita em 134 d.C., pressupõe um texto mais antigo (que o autor atribui a época não posterior à segunda ou terceira década do séc. I d.C.). No texto mais antigo, os amalobrigenses Cabrumúria e Paligão figurariam como os contraentes do pacto com o senado e povo de Cauca. O redactor do pacto de 134 d.C. teria integrado o texto mais antigo de uma forma muito inábil, do ponto de vista sintáctico.

Assim, aproveitando a ideia de J. Velaza Frías, reconstituiríamos desta forma a téssera dos inícios do sec. I d.C.:

Tessera hospitalis, pro meritis Elaesi Ottae, Aii filii, (in) nomine cognatio Magilancum, Amallobrigenses Cabrumuria et Paligo fecerunt cum senatu populoque Caucensium in perpetuum sibi liberis posterisque omnibus eorum.

A redacção correcta do pacto de 132 d.C. teria sido:

Granius Silo et Aemilius Sapienus et Iulius Proculus tesseram hospitalem vetustam (vel antiquam), quae egerunt Amallobrigenses Cabrumuria et Paligo, pro meritis Elaesi Otta, Aii filii, (in) nomine cognatio Magilancum, renovarunt cum senatu populoque Caucensium in perpetuum sibi liberis omnibus eorum.

Nesta hipótese, Cabrumuria e Paligo poderiam ter sido, nos inícios do sec. I d.C., magistri ou magistrati de um vicus ou castellum - Amallobriga — e, em 134 d.C., a mesma povoação teria por magistrati, Granius Silo, Aemilius Sapienus e Iulius Proculus.

A esta hipótese não podemos deixar de acrescentar alternativas. É possível que os serviços prestados por Eleso Ota tenham sido o motivo da renovação e não o da assinatura do primeiro pacto. Assim, o texto mais antigo poderia ter sido:

Tesseram hospitalem (in) nomine cognatio Magilancum Amallobrigenses Cabrumuria et Paligo fecerunt cum... 
Tesseram hospitalem Amallobrigenses Cabrumuria et Paligo fecerunt cum...

Cabrumuria et Paligo, Amallobrigenses, tesseram hospitalem fecerunt cum...

Não nos parece oportuno exercitar ainda outras restituições possíveis da téssera mais antiga, pois se nos afigura mais útil considerar outros problemas.

Assim, perguntar-nos-emos se Cabrumúria e Paligão actuaram em nome pessoal ou em nome de todos os Amalobrigenses, na qualidade de magistri da povoação de Amalóbriga (tal como acabámos de sugerir). Para esta pergunta não temos resposta que nos pareça convincente.

Interrogar-nos-emos também sobre se Amallobriga era, ou não, o nome da povoação de Montealegre de Campos, onde a téssera foi achada. Isso implica a revisão de um melindroso problema: o da rede de vias, cidades capitais e povoações secundárias da região.

\subsection{O estatuto político-administrativo de Amallobriga}

A identificação de Cauca com a actual Coca (província de Segóvia) não está em causa. A cidade ficava em território dos antigos Vaqueus.

Amallobriga, segundo o Itinerário de Antonino, 435, 1, ficava numa longa via de Emerita Augusta a Caesaraugusta, a seguir a Albocela. De Amallobriga, a estrada continuava para Septimanca e Nivaria, e, desta, dirigia-se a Cauca.

Aceitando-se a identificação de Albocela com Toro (Zamora) e de Septimanca com Simancas (RoldÁn NERVÁs, 1973 e TIR, Hoja K-30) e tomando como certas as distâncias do Itinerário de Antonino, não há possibilidade de localizar Amallobriga em Montealegre de Campos. As distâncias do Itinerário de Antonino conduzem-nos mais facilmente a situar Amallobriga no Cerro del Castillo (Tordehumos, Valladolid), onde se localiza um castro romanizado (TIR, Hoja K-30) (vid. nossa est. IV).

Quanto a Montealegre de Campos, poderá corresponder à povoação de Gella citada por Ptolemeu, II,6,49. Tem sido esta identificada com a Tela do Itinerário de Antonino, 440, 3 e com a Gela do Anónimo 
de Ravena, IV, 45. Possivelmente, porém, havia uma Gella ou Tela entre Intercatia e Pintia e uma povoação homónima entre Viminacium e Lancia; ou uma delas se chamava Gella e outra Tela (MAÑANES e SolAnA SAÍnZ, 1985: 39 e 103). Poderia Montealegre de Campos corresponder a Gella ou Tela (como, aliás, se sugere em TIR, Hoja K-30)? Infelizmente, a localização de Intercatia e Pintia não é segura (TIR, Hoja K-30; SAnz MíngueZ, 1997: 21-23). Acresce que as distâncias do Itinerário de Antonino relativamente a estas mansiones suscitam muitas dúvidas (Roldán HeRvás, 1973: 89-90). A identificação de Tela ou Gella com Montealegre de Campos é, pois, muito problemática. E mesmo admitindo tal identificação, como explicar o achado, em Montealegre de Campos, da téssera entre os amalobrigenses e o senado e povo de Cauca?

Na hipótese de o castellum (ou vicus?) de Amallobriga, junto do qual haveria uma mansio, estar dependente de Gella, e de esta ter sido capital de civitas, o achado da téssera (ou de uma das diversas cópias que poderiam ter sido feitas da téssera) em Gella seria facilmente explicável.

Esta hipótese não pode, todavia, deixar de suscitar duas reservas:

1. Se fizermos, de Intercatia e Pintia, cidades capitais de civitates (o que, para Pintia, não é seguro), se localizarmos Pintia em Cabezón de Pisuerga e se situarmos as duas cidades bem no centro dos respectivos territoria, não parece haver, entre as civitates de Intercatia e Pintia, muito espaço geográfico para esta outra civitas de Gella. Espaço haveria se situássemos Pintia em Padilla del Duero. Poderemos argumentar que Gella é citada por Ptolemeu e que isso torna muito credível a capitalidade da povoação. Mas também é verdade que nem todas as povoações citadas por Ptolemeu são capitais de civitates. A verosimilhança (ou inverosimilhança) de ter existido uma civitas de Gella implicaria uma análise das características geomorfológicas e do povoamento romano da região, análise que não nos sentimos habilitados a fazer. Devemos todavia observar que Aguilar de Campos (=Intercatia?) e Montealegre de Campos (= Gella?) se encontram em diferentes bacias hidrográficas subsidiárias do rio Douro e que entre Montealegre de Campos e Padilla del Duero se elevam os Montes de Torozos, pelos quais poderia passar um limite.

2. Ainda que as escavações feitas em Montealegre de Campos, na sequência do achado da téssera, tenham sido muito reduzi- 
das, o edifício só muito parcialmente descoberto mais parece corresponder a uma domus do que a dependência de forum. $\mathrm{O}$ achado da téssera numa vivenda não tem fácil explicação, a menos que se trate da domus de Eleso Ota. Isto seria compreensível se a renovação do pacto tivesse sido feita pelos serviços prestados a Cauca por um Eleso Ota amalobrigense que teria residência (principal ou secundária?) em Montealegre de Campos. Teríamos, assim, um pacto celebrado entre os amalobrigenses Cabrumuria e Paligo nos inícios do séc. I d.C. e renovado em 134 d.C. tendo em atenção os serviços prestados a Cauca pela cognatio amalobrigense dos Magilanci (ou por Eleso Ota, em representação da cognatio). Os materiais arqueológicos recolhidos no edifício escavado inseremse facilmente na data da téssera — o que parece conferir alguma viabilidade à nossa hipótese.

\subsection{Regresso à interpretação do texto da téssera}

Para concluir (e acrescentar as nossas dúvidas relativamente à interpretação da téssera), não deixaremos de perguntar-nos se os amalobrigenses, dependentes de Gella, poderiam ter celebrado um pacto com a cidade de Cauca sem intervenção dos magistrados da cidade da qual dependiam. Ou seria o legado Lúcio Semprónio Quadrado, um representante dos magistrados (duúnviros?) de Gella, representante que, em 134 d.C., teria acompanhado a Cauca os amalobrigenses Granius Silo, Aemilius Sapienus e Iulius Proculus, para renovação do pacto inicialmente celebrado com Cabrumuria e Paligo?

Não podemos esquecer que, na téssera de Herrera de Pisuerga (HAEp., 17-20, 1966-1969, n. ${ }^{\circ} 2.452$ ou HERNÁNDEZ GuERRA, 1994: 148, n. ${ }^{\circ}$ 114), a civitas Maggaviensium era governada por três magistri ou magistrati (vid. também CURCHIN, 1990: 38). Parece difícil, porém, considerar Granius Silo, Aemilius Sapienus e Iulius Proculus como magistri de Gella, pois, no caso de Gella ser capital de civitas, provavelmente teria, em 134 d. C., os seus duúnviros. Além disso, aqueles três indivíduos teriam sido identificados como autoridades de Gella, o que não foi feito. A téssera de Montealegre de Campos continua, pois, a levantar problemas de difícil resolução. Mas, para o nosso fim, o essencial é que, nesse documento, um genitivo do plural em -um apareça precedido pelo termo cognatio. 


\subsection{O problema da extensão da cognatio}

Parece existir hoje consenso em que o nome cognatio era o que se dava às "unidades organizativas" de Celtiberos e Vetões que aparecem designadas por genitivos do plural em -um. Por prudência, não excluiremos a possibilidade de tais "unidades organizativas" poderem ter recebidos outro(s) nome(s) para além do de cognatio, numa certa indecisão ou imprecisão vocabular. Não devemos também esquecer a cognatio de Aldeia Nova, no âmbito do conventus Asturum (atrás recordada), que poderá interpretar-se como equivalente da gentilitas dos Zoelae, mais do que como idêntica à cognatio Magilancum de Montealegre. Mas, nesta questão de equivalências, nada é seguro.

A maior parte dos autores considera que essas "unidades organizativas" correspondem a grupos familiares que não excederiam três ou quatro gerações (GoNZÁLEZ RodRÍGUEZ, 1986: 104-105; BELTRÁN, 1994: 89; SALINAS DE FríAs, 1994 (1): 294; SALINAS DE FríAS, 1998: 160; SASTRE PRATS, 1998: 40), embora outros (ou até os mesmos investigadores) admitam a extensão até à sexta geração (BELTRÁN, 1994: 89; Pereira Menaut, 1993: 416 e 421; Le Roux, 1995: 88).

A coexistência de quatro gerações, isto é, o facto de um indivíduo poder conviver com, pelo menos, um dos seus bisavôs (ou uma das suas bisavós) é perfeitamente admissível, mesmo que, eventualmente, pudesse não ter sido frequente. Em Palência, por exemplo, uma Catonia Flavina tratou do funeral do seu proavus, Caius Memmius (HERNÁNDEZ GUERRA, 1994, n. ${ }^{\circ}$ 35).

Também existe consenso quanto a recusar à cognatio o estatuto de clã (GoNZÁLEZ RodRíGUEZ e SANTOS YANGUAS, 1985-1986: 376, recusando igualmente a identificação da cognatio com a gentilitas; SALINAS DE FRÍAS, 1994 (1): 294, negando também a identificação da cognatio com a gens romana; BELTRÁN, 1994: 102-103, reafirmando a equivalência cognatio $=$ gentilitas $=$ gens $=$ genitivos do plural em $-u m$ ).

O problema da extensão geracional ou profundidade da cognatio, bem como o da sua extensão lateral, carecem, porém, de mais detido exame.

Tendo um antepassado comum, a cognatio poderia compreender, relativamente a um ego, não só seus pais, avós e filhos, mas também tios e sobrinhos, tios-avós, primos. A cognatio poderia ter, assim, uma considerável dimensão, que exemplificaremos com o quadro da fig. 3: 


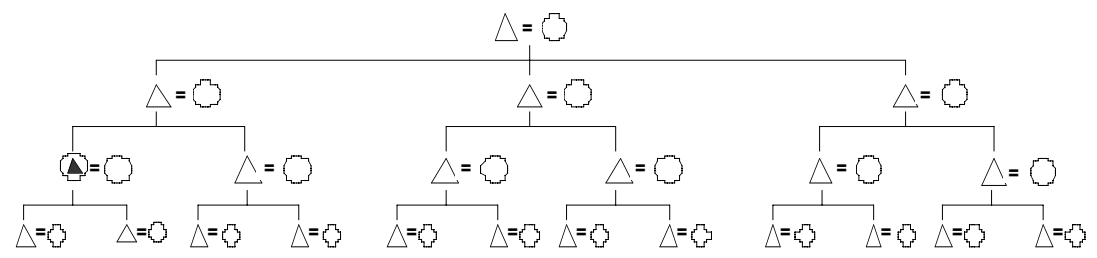

Legenda:
$\triangle$ Varão
Esposa
$\triangle \mathrm{Eg}$ Ego

FIG. 3

Por uma questão de simplificação, imaginamos que o nome familiar, isto é, o que se exprimia por um genitivo do plural em -um, só se transmitiria patrilinearmente, de modo que, relativamente a ego, só os varões descendentes do seu avô eram membros da sua cognatio. As mulheres descendentes do seu avô casariam com homens de outras cognationes, de modo que os primos cruzados, isto é, os filhos da irmã do pai, pertenciam a outra cognatio. Nada, todavia, é mais incerto e não podemos deixar de admitir, com certos autores, como G. Pereira Menaut (1993: 415), a possibilidade de a cognatio ser constituída por todos os descendentes de um antepassado comum, quer por via masculina, quer por via feminina. Mais discutível nos parece a opinião de P. le Roux (1995: 88), para quem a cognatio corresponderia a um grupo de parentes por via feminina, sem que isso impedisse a filiação a patre na indicação do estado civil (e, consequentemente, nas lápides funerárias).

A propósito desta questão, que examinou atentamente, M‥ Cruz González Rodríguez (1997: 83-91) concluiu que a cognatio deveria abarcar tanto a naturalis cognatio, isto é, os familiares por via materna, como a civilis cognatio ou agnatio, isto é, os familiares por via paterna. O exame do seguinte stemma, construído a partir de uma inscrição de Toledo (GonzÁlez RodríGueZ, 1986: C 170), não pode deixar de suscitar dúvidas quanto a essa possibilidade: 


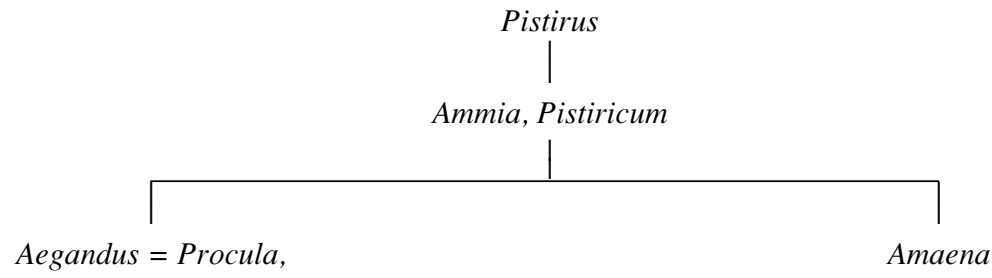

Pentaniqum

Antes de mais, não deixa de surpreender que Ammia, filha de Pistirus, apresente um genitivo do plural coincidente com o nome do pai: esperaríamos que, tendo casado (mas a inscrição não identifica o marido), tivesse integrado a cognatio do marido, isto é, que o genitivo do plural fosse o da cognatio do marido. Ou tratar-se-á de fortuita coincidência, isto é, o pai, Pistirus, não pertenceria a uma "unidade organizativa" designada pelo nome de Pistirici? Por outro lado, os filhos de Ammia, isto é, Aegandus e Amaena, não declaram o nome da "unidade organizativa": seriam Pistirici?

Seja como for, um filho de Aegandus e Procula poderia perfeitamente considerar seus cognati tanto os parentes do pai como os da mãe. Mas essa "família", integrando membros de duas "unidades organizativas", não poderia ter um nome único. Admitindo que Aegandus era, como a mãe, um Pistiricus, poderia dizer: são meus cognati os Pistirici e os Pentanici. Mas esta cognatio que reuniria Pistirici e Pentanici não teria nome próprio. Ora, porque as cognationes têm um nome, a transmissão desse nome deveria fazer-se só por uma linha, mais provavelmente patrilinear. Adiante apresentaremos uma explicação possível para o facto (que este stemma talvez documente) de uma mulher, casando, não assumir o "gentilício" do marido e de os seus filhos assumirem o "gentilício" do avô materno.

Convém citar, neste momento, uma inscrição de Malamoneda (La Puebla de Montalbán, Toledo) (GonzÁlez RodRíGueZ, 1986: C. 152 = Albertos Firmat, 1975, n. ${ }^{\circ} 183$ ):

Licinia, Moenicu(m), B(outi) Paterni, Maganiq(um), f(ília), h(ic) s(ita) e(st). S(it) t(ibi) t(erra) l(evis). F(aciendum) c(uravit) et si(bi) 
Ainda que outras interpretações sejam eventualmente possíveis, é admissível que Licinia, nascida na cognatio dos Maganici, tenha sido integrada na dos Moenici por virtude do casamento. Semelhantes integrações poderão explicar os casos em que marido e mulher pertencem à mesma "unidade organizativa" (GonZÁLEZ RoDRíGUEZ, 1986: 102). Quanto aos casos em que marido e mulher pertencem a "unidades organizativas" diferentes (GoNZÁLEZ RODRíGUEZ, 1986: 102), poderão explicar-se pelo facto de a mulher só ser integrada na "unidade organizativa" do marido depois de ter tido o primeiro filho: assim, a Atta e a Valeria Sucessa das duas inscrições citadas por Mª . Cruz González Rodríguez (1986: 102) teriam sido estéreis.

Admitindo que a nossa hipotética árvore genealógica da anterior fig. 3 reproduz a realidade das relações familiares da cognatio, esta iria crescendo com o passar das gerações e acabaria por ser lateralmente muito extensa, abrangendo primos em grau muito afastado. Só cálculos de probabilidade nos permitiriam dizer ao fim de quantas gerações a cognatio poderia atingir a centena de membros que P. le Roux considera admissível (1995: 88, nota 29). Mas teríamos de partir de um momento em que o fundador da cognatio casasse e teríamos de considerar variáveis tão difíceis de ponderar (esperança média de vida, idade média do casamento, número médio de filhos varões por casal, etc.) que tal exercício nos parece aqui inútil.

Possivelmente, o crescimento da cognatio não era indefinido e certos ramos ir-se-iam tornando independentes, dando origem a outras cognationes, sem que houvesse regras sociais exactas para esse desmembramento.

O fundador da nossa imaginária árvore genealógica, um Abilus, por exemplo, teria dado origem ao nome familiar, Abilicum em genitivo do plural. Ego, chamado Elanus, considerar-se-ia membro dos Abilici. Mas admitamos que, mantendo-se a família no mesmo povoado, Elanus emigrou para outro lugar. Os seus filhos, isolados dos restantes Abilici, teriam constituído nova cognatio e, a partir do nome do pai, adoptariam o de Elanici, donde se formaria o genitivo do plural Elanicum.

É possível que o caso de Matugenus, Matugeniqum, de Ávila (GONZÁlEZ RodríGUEZ, 1986: C. 142), represente exactamente a fundação de uma nova cognatio; mas tal não pode demonstrar-se e não é menos credível que Matugenus seja apenas homónimo de um outro Matugenus que teria sido, muitas gerações atrás, o fundador da cognatio. 
Deslocações, com consequente distanciamento; más relações de convivência; promoção sócio-económica de certos indivíduos - são apenas algumas razões que poderão ter levado à emergência de novas cognationes, com novos nomes.

Se a dimensão lateral de uma cognatio poderia ser grande (incluindo primos afastados), a profundidade temporal poderia ser igualmente considerável: nada obsta a que os membros mais novos de uma determinada cognatio representassem a sétima ou oitava geração descendente do fundador. Apenas o esquecimento em que normalmente caem os antepassados para trás dos bisavôs nos desaconselha a considerar maior profundidade temporal do que a quarta geração para esta "unidade organizativa".

Mas não podemos ignorar que:

1. O nome familiar pode sobreviver mesmo quando o grupo esqueceu o fundador e as gerações mais longínquas.

2. A memória é frequentemente mais longa em sociedades que os antropólogos classificam de tradicionais ou primitivas.

3. A memória dos antepassados é frequentemente mais longa nas famílias de maior status do que nas famílias sócio-economicamente mais débeis ou sócio-culturalmente mais atrasadas.

$\mathrm{Na}$ formação de novas cognationes a partir de um tronco comum, não temos de supor qualquer regularidade: um descendente de terceira geração poderia dar origem a uma nova cognatio enquanto, noutro ramo, só um descendente da quinta geração formaria nova cognatio.

Voltando ainda à genealogia das cognationes, diremos que nos parece mais provável que tenham adoptado a descendência patrilinear. É certo que o facto de, nas inscrições funerárias, o nome dos falecidos ser correntemente seguido pela indicação do nome do pai não prova a patrilinearidade das cognationes, pois, como observa P. Le Roux, aliás já citado, a filiação a patre na indicação do estado civil não é suficiente prova de que a cognatio não era um grupo de filiação uterina (LE RouX, 1995: 88). Mas o pretenso "matriarcado" dos Cântabros, objecto de considerável literatura (v.g. Solana SAínZ, 1998: 243-246; LomAS, 1994), nem sequer se acha suficientemente atestado para os próprios Cântabros.

Poderíamos, é certo, admitir para Vetões e Vaqueus (e para os Celtiberos), um sistema "cognático" tal como a Antropologia Social o define, isto é, um sistema em que nenhuma linha de filiação tem, sobre a 
outra, privilégio ou em que não há relações mais estreitas de um individuo com os parentes do pai do que com os parentes da mãe. Os sistemas cognáticos, assim definidos, são, porém, raros (RADCLIFFE-BROWN e FORDE, 1982: 109-110). Por outro lado, a existência de genitivos do plural em -um que, em muitos casos, se pode confirmar que derivam de antropónimos masculinos (GoNZÁLEZ RoDRÍGUEZ, 1986: 28-30) parece mais facilmente compatível com "unidades organizativas" que se reproduziam em linha agnática ou varonil e não em função da filiação uterina. Correlativamente, parece-nos que a residência virilocal seria a mais comum, isto é, que a mulher, casando, fosse viver com os sogros ou no lugar de residência do marido, adquirindo, de imediato ou na sequência do primeiro parto, a integração na cognatio do marido (GHASARIAN, 1999: 73).

Temos de distinguir, porém, tal como fez Bordieu (citado em GHASARIAN, 1999: 211), as normas e a aplicação prática dessas mesmas normas, aplicação que pode ser mais ou menos desviada das regras em função de estratégias sociais ou familiares que têm de ser entendidas no seu contexto. Assim, voltando ao schema da nossa fig. 3, nada impediria que ego tivesse melhores relações com a família de uma irmã (integrada, pelo casamento, noutra cognatio) do que com os membros da sua própria cognatio. Também não é difícil admitir que, tendo uma irmã de ego ficado a residir na casa paterna mesmo depois do seu casamento (isto é, contra a regra normalmente observada), essa irmã se tivesse mantido integrada na cognatio dos pais (sobretudo em caso de a cognatio do marido ser menos "ilustre"). Os filhos da irmã de ego poderiam ter sido considerados como pertencentes à cognatio de ego (sobretudo em caso de ego ter morrido sem descendência e de os filhos da sua irmã terem ficado seus herdeiros). A tendência normativa que considera todos os comportamentos reais ou práticos como instanciações de normas das quais os indivíduos não podem desviar-se transforma as normas em regras rígidas que, de facto ou na prática, elas não são: as normas são orientadoras mas não cristalizadas ou congeladas.

Vista à luz do que acabámos de dizer, teria explicação uma enigmática inscrição (aliás já anteriormente referida) que, não pertencendo a território de Vaqueus ou Vetões, mas ao dos Ástures Luggoni, diz assim (GONZÁLEZ RODRÍGUEZ, 1986: C 160):

[Monument]um p[ositum] [dib]us Manibus. [Scorcia?] [O]nnacau(m), Ammiae 
Caelionigae, ex gente Pentioru(m), anno(rum) XV, pater filiae posuit. Do(mino) no(stro) Pos(tumo) IIII et Vict(orino) co(n)s(ulibus).

Neste caso, pertencendo a filha, Ammia Caelioniga, a uma "unidade organizativa" diferente da do pai, será que [Scorcia?], casando, veio viver com a mulher e os sogros e que a filha, infelizmente falecida antes de se casar, tinha a "unidade organizativa" da mãe e dos avós paternos? Será que os Onnacaui eram menos ilustres que os Pentii? Será essa, como já anteriormente aventámos, a explicação do "genitivo" da filha?

Possivelmente extensa, isto é, integrando elevado número de membros, ou mesmo sem grande profundidade nem extensão lateral, a cognatio não seria, na época romana, uma unidade de produção e consumo, quer dizer, não haveria terras cultivadas nem gados que fossem propriedade comum do cognatio (embora alguma forma de propriedade colectiva pudesse ter existido na época pré-romana). A cognatio compreenderia diversos grupos domésticos (unidades de residência ou grupos vivendo sob o mesmo tecto, fossem famílias nucleares ou de alguma maneira mais extensas).

Cada grupo doméstico teria seus bens (em termos de terra e gados), e cada grupo é que corresponderia a uma unidade de produção e consumo. A cognatio, na globalidade dos seus grupos domésticos, seria talvez uma unidade exogâmica: os membros de uma cognatio teriam de escolher cônjuge noutra cognatio. É possível, porém, que cada cognatio tivesse uma área própria na necrópole do povoado e constituísse um grupo de nojo, isto é, que a morte de um membro enlutasse toda a cognatio. Assim, repetindo o que já anteriormente dissemos, entenderíamos melhor a fórmula tão frequente nas inscrições funerárias: Gaio, filho de Gaio, sem menção de dedicante, porque dedicantes seriam todos os membros da cognatio. Entenderíamos também melhor por que razão tão raramente se repete, no mesmo povoado, o mesmo genitivo do plural (SÁNCHEZ MORENO, 1996: 121-125): uma inscrição de um membro com indicação da cognatio consagraria o talhão cemiterial como próprio dessa cognatio e os outros membros do grupo não careciam de levar a indicação de "unidade organizativa" porque seria óbvio que, ali enterrados, faziam parte da mesma cognatio.

A repetição do mesmo genitivo do plural na mesma localidade poderia corresponder à instalação de novo talhão sepulcral quando o primeiro se achava esgotado. 
Entenderíamos também melhor, no caso de os dedicantes serem todos os cognati do falecido, a razão por que o dedicado, às vezes, nem sequer leva filiação, como no caso seguinte (GoNZÁlEZ RoDRíGUEZ, 1986: C 139):

Atto, Manuciq(um), an(norum) L. S(it) t(ibi) t(erra) l(evis).

Confrontada esta inscrição com o formulário normal dos epitáfios romanos, ela manifesta uma (deliberada) ocultação da filiação e do(s) dedicante(s). Se escrevemos "deliberada" entre parênteses é por termos dúvidas sobre se a ocultação se deve interpretar como um acto reflexivo, eventualmente assumindo, com plena consciência, uma oposição à norma de indicar, nas inscrições funerárias, o nome do pai e o(s) do(s) dedicante(s), ou como um habitus no sentido que Bourdieu deu a este termo, isto é, como prática não reflexiva, acto que se pratica sem plena consciência da norma social que o enforma, por estar essa norma tão profundamente arreigada no subconsciente que não se tem dela clara representação como norma que se pode seguir ou a que se pode eventualmente desobedecer ou que se pode contestar (vid. BouRDIEU, 1994: 87 s.). Se não neste caso concreto, é possível que, em muitos outros similares, aqueles que encomendavam a inscrição funerária residissem num lugar onde outras famílias, ao encomendarem os epitáfios, instruíam o lapicida para que, na inscrição, fossem nomeados o pai e o(s) dedicante(s). É por isso que admitimos ser a ocultação, deliberada. Podemos mesmo imaginar, com foros de verosimilhança, o lapicida estranhando: - Não quer mesmo que eu ponha o nome do pai e de quem trata do funeral? E os encomendantes, dizendo: - Não, não queremos.

Deliberada ou não, esta omissão não pode deixar de ser significativa. E o que ela significa, ou o que nos parece que significa, é uma grande solidariedade da família alargada (ou cognatio). O nome do pai e o(s) nome(s) do(s) dedicante(s) eram considerados irrelevantes. O que importava era dizer a que grande família ou "unidade organizativa" pertencia, neste caso, Attus. Com alguma verosimilhança podemos supor que o dedicante não foi, neste caso, a viúva, um filho ou filha de Attus, mas toda a família, com eventuais irmãos e cunhadas, filhos e filhas, sobrinhos, sobrinhas e netos, todos associados no funeral. A indicação de que Attus pertencia à família (cognatio?) dos Manucici tornava de alguma forma redundante a indicação do dedicante porque se tornava implícito que este era toda a família dos Manucici. 
A existência de numerosas inscrições nas quais, para além da indicação da família, sob a forma de genitivo do plural em -um, se indicam o nome do pai e do(s) dedicante(s), sejam este(s) marido ou mulher, filho, filha, ou filhos, não nos parece que mude muito ao essencial, isto é, à existência de laços muito fortes no seio da família (cognatio?).

Infelizmente não temos, no território dos Vetões, nenhuma necrópole romana escavada com suficiente extensão e rigor nem (e sobretudo) onde as lápides funerárias se tenham mantido in situ. No castro de Yecla de Yeltes (Salamaca), há quatro necrópoles e destas provêm 58 inscrições (MARTIN VALLS, 1982; TIR - Hoja K-29: 111). Nestas 58, há 16 que apresentam genitivos do plural (sendo apenas um deles repetido em duas inscrições). É óbvio que não podemos atribuir uma necrópole a cada cognatio. Mas não haveria, em cada necrópole, um talhão para cada cognatio? Para "apropriar" o talhão ou para claramente o identificar como pertença desta ou daquela cognatio, bastaria, como dissemos, uma inscrição com o nome dessa cognatio. Não temos sequer que pensar que a lápide com menção da cognatio seria uma lápide fundacional. É possível que os talhões cemiteriais familiares tenham precedido o uso da epigrafia ou, por outras palavras, que a lápide com indicação do genitivo do plural em -um tenha sido erguida quando o talhão era já propriedade da família há várias gerações. Nem temos de supor que, tendo uma cognatio instalado, no seu talhão, uma lápide funerária com genitivo do plural em -um, todas as outras lhe tenham imediatamente seguido o exemplo.

Talvez as cognationes tenham sido, como sustentou Pereira Menaut (1993: 424), "una institución de carácter privado, sin duda muy importante para la vida de los indivíduos, pero irrelevantes para la vida de la comunidad, com la que no se interfieren". Também para F. Beltrán (1994: 90), "puede concluir-se que las estructuras de parentesco en la Hispania céltica juegan un papel relevante dentro del ámbito social doméstico y familiar, pero no en el comunitário o político" (ideia repetida em BELTRÁN, 1994: 103).

Talvez semelhantes afirmações devam, porém, mitigar-se, admitindo considerável papel na estruturação do todo social de uma aldeia, castellum ou vicus sem que os órgãos do poder local, quaisquer que fossem, tivessem representatividade das diversas cognationes. Mas nem sequer isso mesmo se pode afirmar com segurança. 
Segundo alguns autores (entre outros, Pereira Menaut, 1993: 418; GONZÁLEZ RodRÍGUEZ, 1997: 79), uma cognatio podia ter membros em diversos povoados, mesmo muito distantes. Não negando, em absoluto, tal possibilidade, não consideramos que a presença de idênticos genitivos do plural em diferentes localidades (GONZÁLEZ RoDRíguez, 1986: 31; Pereira Menaut, 1993: 418; Salinas de Frías, 1994 (1): 294; SÁnchez Moreno, 1996: 121-125 e 139; Gomez-PANTOJA, 1996) seja prova segura disso mesmo. Com efeito, pode tratar-se simplesmente de cognationes homónimas.

\subsection{O problema da ausência de genitivos do plural}

Se, no território de Vetões e Celtiberos, são numerosas as inscrições funerárias em que os dedicados se integram em cognationes (ou em "unidades organizativas" designadas por genitivos do plural em -um), é maior o número das epígrafes nas quais não há menção de tais unidades. Vários autores têm chamado a atenção para o facto, sem terem logrado uma explicação convincente. Manuel Salinas de Frías, por exemplo, observa que, num total de 423 menções onomásticas das províncias de Salamanca e Ávila, apenas 39, isto é, menos de 10\%, referem uma "unidade organizativa". E acrescenta: "La conclusión que se desprende és, más bien, que la mención de gentilitas o cognatio en las inscripciones es algo residual o poco importante, que en la inmensa mayoría de los casos no se hacía, y que realmente no sabemos por qué en unos casos un indivíduo juzgaba necesario consignar esto dato en la inscripción y en otros no". Mais adiante, voltando ao problema, diz: "La única respuesta que por el momento parece aceptable, aunque pueda parecer ligera o frívola, es que en la perduración de los usos onomásticos indígenas, como es la mención de la gentilitas (recorde-se que, para M. Salinas de Frías, existe equivalência entre gentilitas e cognatio), jugaron su papel tal vez razones como el deseo de distinguirse de outras poblaciones de la zona, orgullos y prejuícios locales cuyas motivaciones, por desgracia para el historiador, se nos escapan" (SALINAS DE FRÍAs, 1994 (1): 293 e 295).

Observando igualmente a existência, nas mesmas regiões e na mesma época, de lápides com genitivos do plural e outras sem eles, F. Beltrán (1994: 86) pergunta-se se os grupos de parentesco afectavam a toda a sociedade, ou apenas determinados sectores. E E. Sán- 
chez Moreno (1996: 118-119) interroga-se por que razão, em Yecla de Yeltes (Salamanca), umas inscrições apresentam genitivos do plural e outras, não.

Se a hipótese de talhões cemiteriais, anteriormente exposta, pode explicar, em parte, esta presença/ausência que não se nos afigura fácil de entender, não nos parece que constitua explicação suficiente e universal, isto é, válida para todos os casos. Perguntamo-nos se, a partir da análise existencial na linha de Heidegger, não poderemos propor uma explicação complementar verosímil.

Poderá parecer pretensioso ou desajustado convocar Heidegger para a discussão deste problema. Mas não será originalidade nossa recorrer ao mestre de Friburgo e Marburgo, pois outros autores (por exemplo, KARLSSON, 1998 e 2000) defenderam já o recurso a Heidegger para resolver ou equacionar melhor certos problemas da investigação arqueológica. Aliás, o problema que se nos põe não é um problema "arqueológico", mas de história social, ainda que, na falta de fontes literárias ou jurídicas, só possamos dispor, para o resolver, de dados que a arqueologia e a epigrafia nos proporcionam (ou, talvez melhor, de dados epigráficos cuja correcta interpretação carece de uma contextualização arqueológica dos mesmos dados).

Ser-aí e ser-com-outros são dimensões ontológicas radicais ou fundamentais do ser humano, sobre as quais Heidegger, superando o ainda cartesianismo da fenomenologia de Husserl, claramente discorreu.

$\mathrm{Na}$ sua factualidade e concretude, todo o homem está-aí e estácom-outros.

O estar-aí reporta-se ao posicionamento físico, no qual temos de considerar várias escalas ou, metaforicamente, círculos concêntricos. A casa em que o homem vive é um aí. Não representa, porém, a escala mínima, porque, na casa em que vivia, o homem estava ainda, mais concretamente, e consoante as horas do dia e as ocupações, no triclinium da casa, no cubiculum ou na culina (pensamos, naturalmente, na casa romana). Depois, numa escala maior, a casa integrava-se num povoado; ou, para uma villa ou granja, a casa era o centro de uma propriedade rústica onde o homem passaria a maior parte do seu tempo. Ainda acima, o aí era a civitas na qual o povoado, a villa ou a granja se incluía. Outros aís se poderiam considerar, como o rio junto do qual ficava a villa, a estrada que por ela passava, vinda de outro aí e destinada a outro lugar, ou o monte em cuja encosta se alojava o povoado. 
Para o fim que nos propomos, não interessa senão considerar duas categorias de lugares em que se estava aí: o aglomerado populacional (castellum, aldeia, vicus ou cidade) e o estabelecimento rural isolado (villa, granja ou casal). A expressão "estabelecimento rural isolado", se, por um lado, parece correcta, por outro, não deixa de ser imprópria. Com efeito, o homem que vivia na villa, granja ou casal não estava totalmente insularizado (em termos de posicionamento físico, e independentemente de estar-com-os-outros da família), mas integrado numa rede de outros estabelecimentos rurais com cujos moradores tinha contactos.

O aí em que o homem se situa não é um espaço vazio, mas povoado de coisas de que o homem se serve. Como escrevemos noutro lugar (AlARCÃo, 2000: 18), o homem, sem outros homens, é uma solidão; mas o homem sem objectos não é apenas um pobre; é uma angústia, por falta de situação.

Por inútil para o nosso raciocínio, não discutiremos se as coisas de que nos rodeamos, coisas que estão "ao alcance da mão" ou "à disposição da mão" (Heidegger utiliza o termo zuhanden), são, todas elas, utensílios. Mais importante é pensar que o homem não está-aí como solus ipse, mas acompanhado; isto é, está-com-outros. Igualmente importante é sublinhar que não existe primado do estar-aí sobre o estar-com-outros, pois os outros fazem parte da estrutura fenomenológica do mundo em que o homem está-aí. O mundo é um mundo que o homem comparte, isto é, Mitwelt, "mundo comum" ou "partilhado". Assim se compõe o termo Mitdasein, reunindo mitsein, "estar com" e dasein, "estar aî".

São diversas as relações com os outros: do amor ao ódio, da indiferença ao Fürsorge heideggeriano, que uns traduzem mais literalmente por "assistência" e outros, talvez mais correctamente, por "solicitude". Mas, ainda que um homem se achasse só, como Robinson Crusoe, não deixaria de pensar nos outros. Não, é certo, como aqueles com quem estava; mas como aqueles de cuja companhia se achava privado. Reconhecida como "privação de", a solidão implica ainda a referência a outro(s) com quem gostaríamos de estar ou que, naquele momento, nos fazem falta.

A partir da noção de estar-com-outros, somos conduzidos à ideia de grupo ou, para usar uma expressão de sociólogos, à ideia do nós (GuRvitch, 1979: 145 s.): o nós da família; o nós dos criados de lavoura de uma villa; o nós que correspondia ao conjunto dos habitantes de um castellum, vicus ou cidade. 
Ora num povoado com 500, 1000 ou mais habitantes, a cognatio corresponderia à necessidade, facilmente compreensível, de criar diferentes e mais restritos grupos de nós.

Pondo de lado a relação dialógica do homem com sua mulher (uxor carissima) ou com seu filho (filius pientissimus), que aqui nos não interessa, o primeiro e menor círculo do nós seria a família. A cognatio corresponderia, assim, a um nós funcional e útil, em termos de solidariedade, exogamia, etc.

Como escreveu Ghasarian (1999: 12), "nas sociedades tradicionais, a separação entre parentes e não-parentes é fundamental. Um indivíduo é percepcionado, antes de mais, como membro de um grupo de parentesco por oposição a outros. Ao distinguir entre os indivíduos que fazem parte do grupo e os que dele não fazem parte, o parentesco define unidades sociais precisas".

Imaginemos agora um Talaus, filho de Toncetamus, da cognatio dos Boutieci, deixando o castellum onde até então tinha vivido para se instalar, em lugar mais ou menos distante, numa granja ou villa. A solidariedade com a cognatio perdia-se (ou podia perder-se). A este propósito é ainda útil citar Ghasarian (1999: 151), a propósito do Rif marroquino, onde "as relações agnáticas são definidas pelo bairro (tharfiqt). Todos os membros da patrilinhagem que deixam o seu bairro de origem e se instalam noutros bairros (os de outros grupos de parentesco) são apagados da genealogia do seu próprio grupo. Os seus laços de consanguinidade são esquecidos. A existência de indivíduos que deixaram o grupo residencial não é negada, mas, simplesmente, não é pertinente, e as perguntas do etnólogo em nada alteram tal situação: "Porque quer que falemos disso? Eles já não contam".

Não pretendemos, obviamente, que no caso marroquino se encontra a explicação para o nosso problema, pois não podemos esquecer que a história das populações do Rif não é a dos povos do Noroeste peninsular nas épocas pré-romana e romana, e que a vida social e económica e a ideologia dos marroquinos do Rif não são idênticas às das populações peninsulares. Mas a lição que deste exemplo podemos colher é a de que diversos mecanismos podem explicar a presença/ausência das indicações expressas da cognatio.

Distinguindo as relações familiares ou sociais que poderíamos chamar "objectivas", da "vivência" que cada um tinha dessas mesmas relações, compreenderemos que não seriam apenas regras de natureza jurídica civil que imporiam menção ou omissão dos "gentilícios", mas vivências particulares. 
Se tentarmos imaginar o dia-a-dia num castellum de considerável população, e supusermos que um Talaus mandava seu filho com um recado ou presente a casa de um Talocius, podemos pensar que o filho, chegado a casa de Talocius, diria: - Venho da parte de Talaus. E Talocius, não conhecendo o rapaz, ficaria perplexo por existirem vários Talaui no castro: - Mas quem é teu pai Talaus? E o rapaz diria: - É o Talaus da cognatio (isto é, da família) dos Boutieci. Assim ficava garantida a correcta identificação.

Por outro lado, se Talaus vivesse numa granja, integrada numa rede de granjas vizinhas, e mandasse seu filho à granja, próxima, de um Talocius, este não teria dificuldade de identificação do remetente, porque, naquela rede de granjas, não haveria (ou poderia não haver) senão um Talaus. Assim, num castellum, a cognatio tinha uma utilidade social que não tinha numa granja ou villa. Além disso, o tal distanciamento de que acabámos de falar, citando o caso do Rif, explicaria ainda que um individuo abandonasse a cognatio ou não lhe fizesse referência.

É certo que poderíamos raciocinar diversamente e defender que, apesar de afastado, o Talaus da granja tinha vantagens em se manter ligado à cognatio do seu povoado de origem. Quando se deslocasse ao povoado, por exemplo, por ocasião de festas, tinha interesse em invocar a cognatio para que algum membro da família lhe desse alojamento.

Seria pretensioso, da nossa parte, julgar que encontrámos a explicação para a presença/ausência de referência à cognatio. Queremos simplesmente chamar a atenção para alguns casos nos quais se podem entrevistar possíveis explicações e que ultrapassam aquelas razões tentativamente aduzidas por M. Salinas de Frías no trecho atrás citado: "el deseo de dintinguirse de outras poblaciones de la zona, orgullos y prejuícios locales...".

Não é menos útil observarmos que a ausência de menção expressa da cognatio (através do genitivo do plural) na lápide funerária de um indivíduo não significa necessariamente que esse indivíduo não estava integrado numa cognatio: poderá entender-se no sentido de que não foi considerado útil, nesse caso, expressar ou invocar a cognatio. Se uma visão formalista, normativista e estruturalista ceder o lugar a uma visão contextualista, que acentue o aspecto da utilização prática das normas, cumpridas, ou não, em função de situações e interesses concretos, talvez se abra a porta a novas explicações e mais correctos entendimentos de um problema que tem desafiado a sagacidade dos investigadores. Sendo necessária, a análise "objectiva" das regras mediante as quais se 
constroem as fórmulas funerárias não deve fazer esquecer a "subjectividade" de quem as aplica, isto é, de quem julgou (ou pode ter julgado) inútil, num determinado contexto, citar a cognatio (ou pode ter julgado útil referi-la). O que aqui dissemos não faz mais do que entreabrir essa porta para novos entendimentos.

Nesta tentativa de explicação, temos de considerar ainda o possível impacte da latinização onomástica, que tentaremos imaginar através do seguinte stemma (utilizando os antropónimos de uma inscrição de San Esteban de Gormaz, vid. GonZÁlez RodRíGuEZ, 1986: C. 131):

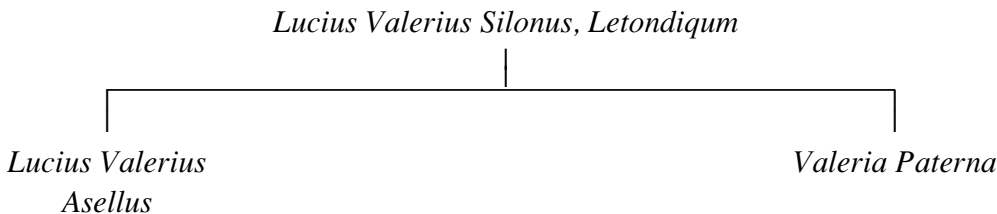

Podemos imaginar que Lúcio Valério Aselo ainda se considerava membro dos Letondici. Mas com igual verosimilhança podemos supor que tenha considerado o gentilício Valerius como suficientemente distintivo. Na cognatio dos Letondici, um ramo poderia ter assumido o gentilício Valerius enquanto outro, por exemplo, teria adoptado o de Antonius, ambos abandonando o anterior de Letondici. Numa fase transicional, os Valerii e os Antonii ainda se considerariam Letondici; depois, teriam abandonado, por supérfluo, o gentilício indígena. Podemos até supor que, nessa fase transicional, a invocação do gentilício Letondici seria útil para evitar casamentos entre Valerii e Antonii, que teriam próximo parentesco. Com o passar das gerações e o distanciamento genealógico dos Valerii e Antonii relativamente ao antepassado comum, o casamento entre Valerii e Antonii seria possível sem escândalo e a invocação do nome comum de Letondici seria, não só inútil, como socialmente limitadora de estratégias matrimoniais e impeditiva ou dificultadora de uma desejada liberdade na negociação de novas relacionações sociais. Invocando a comum estirpe dos Letondici, os Valerii e Antonii sentir-se-iam obrigados a manter relações privilegiados entre eles. Abandonando o nome de Letondici, os Valerii sentir-se-iam livres para criar, com outra família do lugar (por exemplo, os Terentii), relações de amicitia mais fortes do que com os Antonii. Mais uma vez, 
a presença/ausência da menção da cognatio ganha sentido no quadro das estratégias sociais e nos contextos históricos.

\subsection{O melindroso problema dos genitivos do plural dos Vaqueus}

A raridade dos genitivos do plural em -um entre os Vaqueus deve levar-nos a perguntar: porquê tão poucas ocorrências?

Com efeito, conhecem-se apenas: $\operatorname{Argantioq}(u m), C a r i q o(n)$ e $C e c$ ciq(um), respectivamente, de Palência (= Pallantia), Coca $(=$ Cauca) e Paredes de Nava (GonzÁlez RodríGuez, 1986: C. 35, 86 e 90); e Magilancum, da téssera de Montealegre de Campos. A leitura de Etommoq(um) numa lápide de Valência de Don Juan (GonZÁLEZ RoDRíGUEZ, 1986: C. 122) não se confirma (ERPL, n. $\left.{ }^{\circ} 230\right)$. O texto de uma outra inscrição de Palência onde se leria Amalcu(m) (HERNÁndeZ GuERRA, 1994: 106-107, n. ${ }^{\circ}$ 84) é demasiadamente duvidoso.

A téssera de Paredes de Nava, encontrada num castro importante a cerca de 22 Km de Palência (TIR, Hoja K-30: Madrid, voc. Páramo Ciudad, castro que parece dever identificar-se com Intercatia, vid. CASTELlano e Gimeno, 1999: 361-362 e Solana SÁinZ, 1983: 42), contém um texto breve: Caisaros, Cecciq(um), pr(inceps) Arcailo (...) (HeRNÁNDEZ GuERRA, 1994: 147, n. ${ }^{\circ} 113$; RoDRíGUEZ NEILA, 1998: 127, restituindo praetor em vez de princeps; CASTELLANO e GIMENO, 1999: 330, restituindo $K(a) r$, palavra que significaria hospitium). Talvez se deva interpretar no sentido de que Caisaros (=Caesarus), da cognatio dos Cecciqi (=Caecici, com um sufixo celtibérico -iko), era princeps, isto é, chefe dos Arcailon (=Argaelorum). Admitindo um castellum Argaelum, os seus habitantes poderiam ser chamados Argaeli. A téssera nomearia o princeps ou autoridade máxima do castellum, príncipe que seria membro da família dos Cecciqi. Será que, entre os Vaqueus, em época anterior à conquista romana, só a família dominante (ou duas ou três famílias de maior status) de um castro teria(m) nome(s) gentilício(s)? Será que a generalidade da população se identificava simplesmente como Gaius, filho de Gaius?

Outra téssera achada no mesmo lugar de Paredes de Nava (HeRNÁNDEZ GUERRA, 1994: 145, n. ${ }^{\circ} 112$, com bibliografia), datada do período de 2 a 14 d.C., parece viabilizar essa hipótese. Neste outro texto, um Acces, filho de Licirnus, natural de Intercatia, por um lado e a civitas Pallantina, por outro, fazem um pacto de hospitalidade. O final da 
mesma téssera poderá, talvez, interpretar-se no sentido de que Anenius, Ammedi (filius), residente em Paredes de Nava, recebeu em sua casa a Ammius, Caenecaeni (filius).

Poderíamos ter, neste caso, um acordo entre uma família de Intercatia (a de Acces) e a cidade de Pallantia, acordo nos termos do qual Anenius adoptou Ammius, que seria parente (neto? sobrinho?) de Acces. A "adopção" teria requerido o pacto genérico de hospitalidade celebrado por Acces, para si, seus filhos e descendentes.

A ausência de genitivo do plural para Acces ou Ammius, de quem se indica apenas a filiação, confirma que, mesmo numa época antiga (a de Augusto), nem todos, em Paredes de Nava, estavam integrados numa "unidade organizativa" expressa por genitivo do plural em -um: nessa localidade, apenas Caisarus, o princeps, teria um "gentilício" (ou apenas a sua família teria um nome familiar que se transmitiria de geração em geração).

Podemos argumentar que Caisaros não era o príncipe do castro onde a téssera foi achada, mas de um outro castellum. De qualquer forma, isso não invalida a hipótese de os genitivos do plural, entre os Vaqueus, serem reservados a famílias de maior status. Na época préromana, tais famílias seriam as principais dos castros. $\mathrm{Na}$ época de Augusto, a civitas Pallantina seria governada por um magister (ou, mais provavelmente, por dois ou quatro magistri, dos quais o Elaisicus da téssera de Paredes de Nava seria apenas um), mas as antigas famílias nobres manteriam os seus nomes gentilícios.

Na hipótese de, na téssera, se dever ler $K(a) r$, tratar-se-ia de um pacto entre Caisaros e uma outra personagem (Arcailus ou Argaelus) ou família ou ainda moradores de um castellum (Argaeli).

Destas famílias nobres vaceias (ou destes príncipes) parece haver testemunho na necrópole de Las Ruedas (Padilla del Duero, Valladolid) (SANZ MíngueZ, 1998).

Nas escavações efectuadas neste cemitério, cujo esquema reproduzimos na nossa est. V, uma segunda fase, que C. Sanz Mínguez data de meados a finais do séc. IV a.C. (ou mesmo a inícios do séc. III), compreende os sectores II-N/II-O a II-T/IIY. Os sectores II-Y/II-AA a II-AI/II-AJ situar-se-iam no séc. III e na primeira metade do séc. II a.C.

Ora, no primeiro dos sectores citados, a sepultura n. ${ }^{\circ} 28$ corresponderia a um chefe e as que se situam próximas dele pertenceriam aos seus parentes. Situação similar se verifica no segundo dos citados sectores, com a sepultura de chefe n. ${ }^{\circ} 32$. 
A necrópole de Las Ruedas sustenta, pois, a ideia de chefes ou príncipes, já desde finais do séc. IV ou inícios do III a.C., nos castros vaceios - castros que, de um modo geral, são grandes e distantes uns dos outros: $80 \%$ dos povoados têm dimensões superiores a 5 hectares e distanciam-se de 12 quilómetros ou mais uns dos outros.

A planta esquemática da necrópole, que reproduzimos, manifesta, sobretudo entre II-T e II-AM, conjuntos separados por espaços vazios, conjuntos que parecem suportar a nossa ideia, anteriormente expressa, de talhões familiares nas necrópoles. O talhão da necrópole de Las Ruedas que compreende as sepulturas 35 a 46 tem $24 \mathrm{~m}^{2}$, área que se harmoniza com as dimensões de talhões cemiteriais familiares romanos (VAQUERIZO, 2002: 186).

Assim, os poucos genitivos do plural em -um que se encontram entre os Vaqueus poderão corresponder a aristoi ou famílias nobres. Mas não pretendemos dizer com isso que, em época pré-romana ou romana, os indivíduos se identificariam simplesmente como Gaius, filho de Gaius. Ainda que as fórmulas onomásticas funerárias nos possam fazer pensar nisso mesmo, vimos atrás os equívocos que, no dia a dia, poderiam surgir de tão simples identificação. Vimos também como sociedades tradicionais sentem necessidade de criar grupos de nós, correspondentes a famílias "indivisas", "alargadas" ou "múltiplas". Por estes termos se designa a família que, mantendo-se unida, integra unidades domésticas, isto é, várias famílias nucleares ou reduzidas que vivem, cada uma, em sua residência (GHASARIAN, 1999: 41). O seguinte stemma permite-nos imaginar a situação:

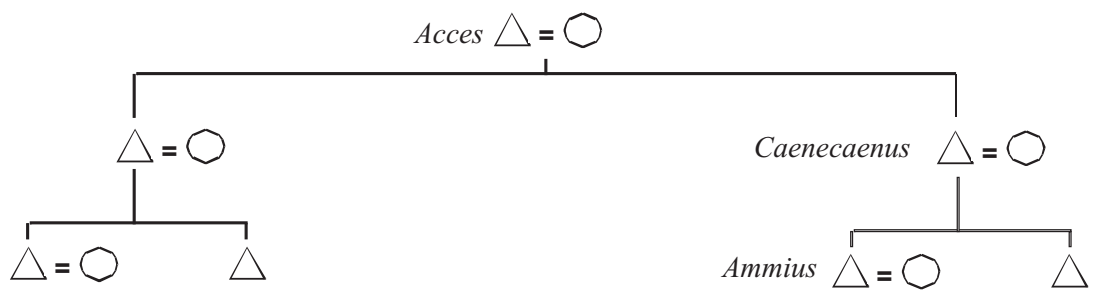

Legenda

Homem

Mulher

= Ligação Matrimonial

FIG. 4 
Os indivíduos representados no stemma poderiam não viver todos sob o mesmo tecto. Ammius, por exemplo, podia viver com seu pai Caenecaenus numa residência diferente da do filho primogénito de Acces. Mas Ammius poderia identificar-se como filho de Caenecaenus e neto de Acces, ou como membro da família, estirpe ou linhagem de Acces. As famílias assim definidas (que poderiam ter maior número de membros que os representados na nossa figura) não careceriam de gentilícios ou nomes familiares porque se identificavam pela referência ao sénior, isto é, ao mais velho do grupo, que poderia ser, por exemplo um tio-avô. Um filho de Ammius, se Acces fosse já falecido, podia dar como referência o filho primogénito de Acces, que passaria a ser, por morte deste último, o sénior da família.

\subsection{Regresso à interpretação do termo cognatio}

A nossa hipótese de, entre os Vaqueus, os genitivos do plural em -um corresponderem a gentilícios de umas poucas famílias de maior status obriga-nos a reconsiderar o que, anteriormente, parecia consensual: a utilização do termo cognatio para designar as "unidades organizativas" nomeadas por genitivos do plural em -um.

Com efeito, parece-nos agora que poderia haver um mundo (o dos Vetões e Celtiberos) em que o comum da população se integrava em "unidades organizativas" designadas por tais genitivos e um outroas por tais genitivos e um outroses genitivos do plural eram reservados a umas poucas famílias. Ora a téssera de Montealegre de Campos, onde se regista o nome cognatio, encontrou-se em território de Vaqueus. Os Magilanci não seriam uma dessas famílias nobres? Seriam designadas pelo termo de cognatio também as famílias comuns de que em Yecla de Yeltes encontramos 13 ou 14 exemplos? Mas, se o não eram, que nome se usava, na época romana? Se os Ammarici ou os Combarici de Yecla de Yeltes não eram cognationes, o que seriam então? Ou mais correctamente: que nome comum designaria tais unidades?

Tal como várias vezes, ao longo deste artigo, temos adiado respostas às nossas perguntas, adiaremos uma vez mais uma opinião sobre este assunto, sobre o qual nos pronunciaremos depois de considerarmos o caso dos Vadinienses. 


\section{Os genitivos do plural dos Vadinienses}

Os genitivos do plural em -um são numerosos no território dos Cântabros Vadinienses: em cerca de 76 inscrições funerárias, pelo menos 19, isto é 25\%, registam tais genitivos (Garcia Merino, 1975: 404 s.; GonZÁlez e SANTOS, 1984; GonZÁlez RodrígueZ, 1986; Solana SÁInZ, 1998: 240-241; Rabanal Alonso e Garcia Martínez, 2001: 379 s.).

As expressões que usámos, "cerca de" e "pelo menos", justificamse por dificuldades de leitura e/ou de reconstituição de algumas inscrições ${ }^{1}$. Além disso, certos nomes em -inus deixam dúvidas sobre se se trata de antropónimos ou de designações de "unidades organizativas" (PRÓSPER, 2002: 299-300)². De qualquer forma, não nos parece que uma revisão muito atenta do corpus das inscrições funerárias vadinienses possa alterar substancialmente os números apontados.

Nuns casos, os genitivos do plural vadinienses são apostos ao nome do dedicante; noutros, ao do dedicado; num só caso, ambos, dedicado e dedicante, levam genitivos do plural, aliás, diferentes:

- D(is) M(anibus). Vadone Biracidegino, Anemidi f(ilio), Va(diniensesi), an(norum) XXX. Lugua, Caddecun, amico suo pos(u)it. H(ic) s(itus) e(st).

De La Remolina (GonzÁlez RodRíGuEZ, 1986: C. $66=$ $E R P L, \mathrm{n} .^{\circ} 395$, com diferente leitura do nome do dedicado).

- D(is) M(anibus). [T]urenno, Boddegun, Boddi f(ilio), Vad(iniensi), an(norum) XXX, pos(u)it Doiderus, patri suo pientissimo. S(itus) h(oc) s(epulchro). De Argovejo (GonZÁLEZ RodRÍGUEZ, 1986: C. $55=$ ERPL, n. ${ }^{\circ}$ 393).

1 Os próprios dados de Ma․ Cruz González Rodríguez parecem não coincidir. A autora (1997: 117, nota 358), revendo o trabalho de 1986, suprime do rol dos genitivos do plural os n. ${ }^{\circ}$ s 31, 180 e 189 (dos Vadinienses) e 178 (de Guadalajara). Suprimindo três genitivos ao rol de 1986, obteríamos 21 e não os 18 que a autora indica (1997: 117, nota 358 e 1997: 119).

2 Blanca María Prósper (2002: 299-300) afirma, a propósito de alguns nomes em -inus: "Se éstos son casos de atribución de un indivíduo a un grupo suprafamiliar del orden que sea, entonces la derivación por medio de un sufijo nasal *-i/inno- es el sustituto y equivalente funcional del genitivo de plural en -um, o eventualmente el genitivo de singular en - $o$, en que aparecen los adjectivos con sufijo velar que designan nombres de clan en la epigrafía celtibérica". 
- Mon(umentum). Tridio, Alongun, Bode(ri) f(ílio), Vad(iniensi), an(norum) XXV. Fronto, Doiderigum, amico suo pos(u)it. $H$ (ic) s(itus) e(st) t(erra) l(evis). De Villayandre ou La Remolina (GONZÁLEZ RODRÍGUEZ, 1986: C. $19=E R P L, \mathrm{n} .^{\circ} 391$ ).

Os genitivos do plural vadinienses corresponderão a gentilitates ou a cognationes? Ou deverão interpretar-se de outra forma? Terão alguma semelhança com as "comunidades de vale" medievais da Cantábria?

O problema parece complexo. A interpretação dos genitivos do plural vadinienses como designativos de tribos, apresentada por A. Barbero e M. Vigil (1974: 28-29) a partir de uma inscrição de Pico Dobra ${ }^{3}$ com o genitivo Aunigainu( $\mathrm{m}$ ), inscrição supostamente de 399 d.C., mas cuja cronologia deve corrigir-se para 161 d.C. (GonZÁLEZ RodRíGUEZ, 1997: 24-25; IgLesias e Ruíz, 1998: 65-66), não é sustentável e já não tem hoje apoio. Justo é reconhecer-se, porém, que aqueles dois autores hesitaram entre a interpretação do genitivo do plural Ainigainu $(\mathrm{m})$ como nome de tribo ou de clã e que, noutro lugar (1974: 161-169), consideraram os genitivos do plural como designativos de clãs.

Chamando a atenção para a complexidade do problema, $M^{\mathrm{a}}$. Cruz González Rodríguez (1997: 118) diz que "no podemos evitar el perguntarnos si los grupos parentales documentados por medio de genitivos de plural entre los miembros de la civitas Vadiniensis de los siglos II e III d.C. eran exactamente iguales e idénticos a la cognatio Magilancum del año 134 d.C.". Parecendo não duvidar de que os genitivos do plural vadinienses designam "grupos parentales", a autora afirma, todavia, que "la idea de que los vadinienses tenían como unidad básica de organización los «grupos gentilícios o clanes» debe matizarse mucho cuando no olvidarse" (1997: 119).

As dúvidas de Ma․ Cruz González Rodríguez sobre a natureza das "unidades organizativas" vadinienses designadas por genitivos do plural são inteiramente pertinentes (do nosso ponto de vista): não é claro que elas sejam "cognationes" (tal como anteriormente as definimos), nem é fácil sustentar que sejam gentilitates (tal como as propusemos para os Zoelas).

$\mathrm{Na}$ análise do problema que se nos põe, procederemos por partes.

3 Pico Dobra deve, talvez, atribuir-se aos Cântabros Blendii. Em nenhum caso, aos Vadinienses. 


\subsection{As formas de povoamento e a economia dos Vadinienses}

Os Vadinienses constituíam um populus / uma civitas integrado no grupo mais vasto dos Cantabri. Mais adiante tentaremos identificar esses outros populi cântabros.

Para os Vadinienses, sugeriu-se que teriam, ainda na época romana, uma vida nómada, correlacionada com uma economia essencialmente pastoril (BARBERO e VIGIL, 1974: 169).

A ideia de nomadismo dos Vadinienses deu hoje lugar à de transumância (GoNZÁLEZ RoDRíGUEZ, 1997: 102), possivelmente mais correcta. Mas a hipótese de um "habitat principal situado en las montañas y uno muy precário ubicado en la llanura, para las personas y los animales durante el invierno" (GonZÁLEZ RodRíGUEZ, 1997: 102-103) poderá carecer ainda de revisão.

O nosso (pessoal) desconhecimento (ou conhecimento escasso) da geografia, etnografia, arqueologia e história da Cantábria não nos permite abordar devidamente o assunto. Não deixaremos, porém, de observar que, na Itália Central, desde a Idade do Bronze, a transumância não exclui povoados permanentes (BARKER, 1972; para o estudo da transumância na Europa na Pré-história Recente, BARKER, 1985). Por outro lado, na serra do Gerês (ou, em galego, do Xurés), até à época contemporânea, a transumância era mais frequentemente feita entre um povoado mais baixo e um pasto estival nas montanhas (SouSA, 1927: 12s.). Os rebanhos, mesmo grandes, seriam conduzidos por reduzido número de pastores, pelo que a maioria da população viveria no "habitat permanente". Em torno deste, praticar-se-ia a agricultura, mesmo que, eventualmente, esta se fizesse por roças ou roçadas, isto é, mudando frequentemente os campos onde se cultivariam os cereais e deixando de pousio durante alguns anos os que haviam sido trabalhados. Mas este mesmo tipo de agricultura cerealífera é duvidoso e só a análise das características pedológicas e edafológicas dos terrenos em torno dos lugares ocupados nos permitiria deduzir se a cultura permanente dos mesmos campos não seria, afinal, para os Vadinienses da época romana, uma alternativa mais verosímil.

Assim, não só a tese do nomadismo nos parece questionável, como a transumância não deve fazer-nos perder de vista a possível residência da maior parte da população, permanentemente, em lugares estáveis (duvidando do nomadismo dos Vadinienses, vid. também SASTRE PRATS, 2001: 156-157). 
A expressão "habitat" que anteriormente usámos, e que foi também empregue por Mํ. Cruz González Rodríguez no trecho acima transcrito (distinguindo um "habitat principal" e um "habitat muy precário") é, todavia, demasiadamente imprecisa, pois nela cabem diversos tipos de estabelecimentos. Viveriam os Vadinienses concentrados em castella, aldeias ou vici, ou dispersos por villae, granjas e casais? ${ }^{4}$ Infelizmente, pouco se conhece sobre a forma como a população vadiniense se concentrava ou dispersava. Não temos, para o território vadiniense (nem sequer para parte dele), um estudo do género daquele que Sande Lemos elaborou para a parte oriental da província de Trás-os-Montes (LEMOS, 1993, completado por CRUZ, 2000) ou do que, geograficamente mais limitado, Almudena Orejas (1996) consagrou à cuenca noroccidental del Duero.

Seja como for, parece credível que, no território vadiniense, houvesse vici e/ou aldeias (SASTRE PRATS, 2001: 155). Crémenes, por exemplo, terá sido um aglomerado de alguma importância, a julgar pelas oito inscrições aí recolhidas (uma votiva e sete funerárias).

Se bem que seja duvidosa, ou mesmo ignorada, a procedência exacta de muitas das inscrições vadinienses, a maior parte, porém, parecer corresponder a achados singulares. Isto é: há muitos sítios onde se recolheu uma inscrição mas não se encontrou segunda (vid. nossa est. VI). Muito provavelmente, neste caso, as inscrições correspondem a modestas villae ou, talvez melhor, a granjas. Dificilmente admitiremos que possam corresponder a simples casais, pois os habitantes destes não teriam nem meios económicos nem estatuto sociocultural que lhes permitisse encomendar, para um dos seus membros falecidos, uma lápide funerária.

Não deve estranhar-se que numa modesta villa ou granja, ainda que ocupada durante dois ou três séculos, se encontre apenas uma inscrição funerária. O facto é normal mesmo em ricas villae, onde múltiplas inscrições funerárias são raras e onde, muito mais frequentemente,

4 Por "casal" entendemos uma modesta exploração unifamiliar; por "granja", uma exploração cujo proprietário, empregando já criados de lavoura, visava obter um excedente de produção que lhe permitia uma vida confortável. O casal tinha uma pequena habitação com os necessários anexos; a granja tinha já uma parte construída considerável, se bem que sem o luxo de uma villa. Em termos de propriedade fundiária, o casal não exploraria, possivelmente, mais que 2 ou 3 hectares, enquanto o dono de uma granja poderia ter mais de 10 hectares de terra (variando a extensão da propriedade consoante as regiões e a fertilidade dos solos). 
se acham inscrições únicas. Não cabe aqui uma análise pormenorizada do porquê desse facto, que, neste momento, apenas pretendemos assinalar, prevenindo a possível objecção de ser pouco credível encontrarse uma única inscrição funerária numa granja ocupada durante muitas gerações. Talvez um único epitáfio (que, numa villa, em alguns casos, poderia estar integrado num mausoléu) fosse considerado suficiente para identificar a família proprietária ou simbolicamente "apropriar" a necrópole.

Assim, à hipótese de uma população nómada e transumante, contrapomos outra hipótese (que, todavia, carece de verificação): os Vadinienses viveriam em lugares estáveis, uns, concentrados em aldeias, castella ou vici e outros, dispersos por granjas e casais.

\subsection{A epigrafia de Crémenes e Corao}

A actual povoação de Crémenes poderá corresponder a um antigo vicus ou aldeia vadiniense. Com efeito, uma inscrição votiva a Júpiter Óptimo Máximo e sete funerárias (ERPL, n. ${ }^{\circ}$ s 44, 366, 377, 384, 387, 389, 398 e 399) são credível testemunho de um povoado romano de alguma importância, mesmo que dele não existam outros testemunhos (ou ter-se-ão achado em Crémenes, para além das inscrições, vestígios arqueológicos que não sejam do nosso conhecimento?).

Em nenhuma das inscrições funerárias de Crémenes se regista genitivo do plural, pois a memória sepulcral de Iunius, Arauu(m), Abili filius parece ter sido encontrada em Cármenes e não em Crémenes (ERPL, n. ${ }^{\circ}$ 378) e porque Mํ. Cruz González Rodríguez, tendo primeiramente tomado $\operatorname{Arauu}(m)$ como genitivo do plural, admite agora a restituição $\operatorname{Arauu}(s)$, que faria do nome um antropónimo e não um genitivo do plural (GONZÁLEZ RoDRíGUEZ, 1997: 117, nota 358).

Mesmo admitindo, como dissemos, a possibilidade de alguns nomes em -inus corresponderem a "unidades organizativas", na inscrição de Crémenes consagrada a Júpiter Óptimo Máximo pro s(alute) F(lavii) Muci(i?) Calistiani (ERPL, n. $\left.{ }^{\circ} 44\right)$, o nome Calistianus parece dever interpretar-se como um cognomen e não como designativo de uma "unidade organizativa" (a de uns eventuais Calistiani).

Sem podermos ainda retirar conclusões, não deixaremos de observar a existência (todavia só verosímil e não confirmada) de uma aldeia ou vicus vadiniense sem genitivos do plural, numa área onde tais geni- 
tivos são comuns. Mas não deixaremos também de reconhecer que a ausência de prova não é prova da inexistência, e que poderia ter havido em Crémenes alguma inscrição com menção de genitivo do plural, que, por acaso, se não tivesse conservado.

Das inscrições de Crémenes, uma foi erigida a Pentius Festus pelos amici, que todavia se não identificam nominalmente (ERPL, n. ${ }^{\circ} 387$ ). Por esta lápide funerária, não se pode confirmar nem desmentir a hipótese de Mㅜ․ Cruz González Rodríguez (1997: 116) de que os amici, tão frequentemente declarados na epigrafia funerária vadiniense, seriam "unos agrupamientos de indivíduos que, muy possiblemente, pertenecían a la élite social vadiniense, la que era capaz de adiestrar los caballos, realizar competiciones hípicas y mostrar sus habilidades en el combate como jinetes".

Parece-nos problemático o significado que Mª . Cruz González Rodríguez dá à frequente representação de cavalos nas lápides funerárias vadinienses e o sentido que a mesma autora atribui ao termo amicus. A estas questões voltaremos mais adiante. Mas não deixaremos de pôr aqui, desde já, uma outra dúvida. Sendo abundantes, nos epitáfios vadinienses, os genitivos do plural (apostos, como vimos, a nomes de dedicados e/ou dedicantes), mas dado que, em muitas outras inscrições, tais genitivos não aparecem, designarão eles famílias de particular status sócio-económico? Haveria uma população de gente miúda que não tinha um "nome de família", e existiriam certas famílias "nobres" que mantinham tais nomes, epigraficamente atestados pelos genitivos do plural? Os genitivos do plural vadinienses não corresponderiam, assim, nem às gentilitates dos Ástures nem às cognationes dos Vetões. Neste caso, a epigrafia de Crémenes seria contraditória se os amici que se encarregaram do funeral de Pentius Festus pertenciam à elite social vadiniense: como explicar, então, a ausência de genitivos do plural nas inscrições recolhidas naquela localidade? Se os amici pertenciam a uma elite social que mantinha "nomes de família" expressos por genitivos do plural, deveriam encontrar-se, em Crémenes, tais genitivos. Fica aqui enunciado um problema (ou um conjunto de problemas) a que teremos de voltar.

Na zona setentrional dos Vadinienses, Corao, de onde se conhecem seis inscrições (GArcía MERINO, 1975: 410-411; GonZÁlez e SANTOS, 1984: 99-100), mas onde haveria mais de vinte (MENÉNDEZ BuEYES, 2001: 208, citando Ambrósio de Morales; Diego SANTOS, 1959: 202), 
terá sido outro núcleo populacional, eventualmente bem mais importante que Crémenes. Não teremos aqui a capital dos Vadinienses, a Vadinia de Ptolemeu? A residência do primeiro rei das Astúrias, Pelágio ou Pelaio e a igreja de Santa Eulália por ele construída (ARIAS, 1993: 12) teriam ficado, assim, perto da capital da antiga civitas romana.

Em Corao, porém, duas inscrições funerárias apresentam genitivos do plural: a de uma Terentia, Aroniaecivorum, que lhe foi consagrada pelo marido; e a de Antonius Paternus, Arcaedunum, realizada por Aelia, sua mãe (GonZÁlEZ RodRíGUEZ, 1986: C. 39 e 32). Numa outra inscrição (GoNZÁLEZ e SANTOS, 1984: 99, n. ${ }^{\circ}$ 8), consagrada Fusci Cabedi (em genitivo), a leitura Cabedi(cum) é problemática e Cabedus poderia ser o segundo nome do dedicado.

A hipótese de estes dois genitivos do plural corresponderem a famílias de maior status em Corao não nos parece inverosímil. A ausência de outros Aroniaecivi e Arcaeduni na epigrafia da Corao teria explicação no quadro da hipótese, anteriormente posta, de talhões familiares no(s) cemitério(s), simbolicamente "apropriados" por meio de uma única inscrição funerária com o nome da família: os outros parentes, sepultados no mesmo talhão, não levariam lápides funerárias ou, se acaso alguns as levassem, não se julgaria necessário repetir o nome familiar.

O argumento (de carácter hipotético) que acabámos de usar não poderá, porém, servir para sustentar que é menos verosímil corresponderem os nomes Aroniaecivi e Arcaeduni a gentilitates.

Ao tratarmos das gentilitates dos Zoelae, e tendo admitido, como possível, a sua natureza de clãs, isto é, de grupos de famílias que se consideravam aparentadas por se auto-representarem como descendentes de um antepassado comum, distante no tempo, mantivemos a dúvida sobre se uma gentilitas corresponderia a um castro ou a um grupo de castros. Aventámos, porém, a partir da análise do "pacto de Astorga", CIL II 2633, a possibilidade de os Romanos terem promovido a instalação de aldeias em que se teriam fixado duas (ou mais) gentilitates (ou membros de duas ou mais gentilitates).

A esta luz, os genitivos do plural de Corao poderiam corresponder a membros de duas gentilitates fixadas no aglomerado.

Em alternativa, os genitivos do plural de Corao poderiam referir-se a imigrantes: em Corao viveria uma gentilitas (ou conviveriam duas ou três gentilitates) e os membros dessa(s) "unidade(s) organizativa(s)" locais seriam sepultados sem menção da gentilitas; só os imigrantes levariam menção da gentilitas da qual procediam. Neste caso, a ausên- 
cia de genitivos do plural em Crémenes explicar-se-ia pela inexistência de imigrantes (ou pelo facto de, casualmente, todas as lápides funerárias até agora encontradas em Crémenes corresponderem a membros de famílias locais e de não se ter descoberto ainda nenhuma inscrição funerária de imigrante).

Não podemos, finalmente (ao menos por enquanto), excluir a hipótese de os genitivos do plural de Corao corresponderem a cognationes. Teríamos, em Corao, um caso semelhante aos de Yecla de Yeltes (Salamanca) e Monte Cildá (Palência). Para mais, não sabemos se algumas das inscrições perdidas de Corao conteriam, ou não, outros genitivos do plural.

Assim, sistematizando as hipóteses (sem pretendermos ainda hierarquizá-las em função da sua maior ou menor verosimilhança), os genitivos do plural vadinienses corresponderiam a uma ou outra das seguintes possibilidades:

1. Famílias de elevado status sócio-económico

2. Gentilitates (tais como as definimos para os Zoelae)

3. Imigrantes procedentes de gentilitates exteriores à(s) que habitava $(\mathrm{m})$ as aldeias ou vici vadinienses

4. Cognationes (tais como as encontrámos em Yecla de Yeltes)

\subsection{Liegos e Verdiago: outros vici ou aldeias?}

É difícil decidir se Liegos (Acebedo) corresponde, ou não, a outra aldeia ou vicus vadiniense. Com efeito, só duas inscrições (ERPL, $\mathrm{n} .^{\circ} \mathrm{s} 370$ e 379) procedem, com segurança, deste lugar: na primeira, um Ces(tius) Fla(uus) dedica a memória funerária a seu pai, Ces(tius) Bod(dus); na segunda, Aliomus recorda a filha, Maisontinia; nenhuma das inscrições contém genitivo do plural. Incerta é a proveniência da lápide de Cludamus ao amicus, Andotus Ubalacinus (ERPL, n. $\left.{ }^{\circ} 357\right)$ e da memória funerária de Neconus, Boddegun, posta por Aurelius Pro(culus) ao seu amicus (ERPL, n. $\left.{ }^{\circ} 383\right)$. Neste último caso, a nossa dúvida resulta de não sabermos situar exactamente o "valle de San Pelayo", onde a inscrição foi encontrada: fica mesmo junto de Liegos, ou um pouco mais distante?

Na inscrição ERPL, n. ${ }^{\circ}$ 357, Ma . Cruz González Rodríguez (1986, C. 189) leu Ubalacino(rum), mas posteriormente corrigiu a leitura, considerando tratar-se de um antropónimo em -inus (1997: 117, nota 358). 
A mesma dúvida, sobre a natureza do lugar, se põe relativamente a Verdiago, donde parecem proceder três inscrições: ERPL, n. ${ }^{\circ}$ s 349, 394 e 401. A primeira regista o genitivo do plural Vir[oni]gum. A curta distância de Verdiago a Crémenes (quatro quilómetros em linha recta) torna duvidosa a identificação de Verdiago como aldeia, mas não invalida inteiramente tal hipótese.

\subsection{Outro vicus ou aldeia em Riaño?}

Em Pedrosa del Rey (Nuevo Riaño) foi encontrada uma inscrição que mereceu a Ma․ Cruz González Rodríguez (1997: 111-117) um extenso comentário:

$D($ is) M(anibus). M(onumentum) p(osuit) Cor(nelius) $M a-$ te(rnus), ciues Vad(iniensis), ex pr(aecepto) eor(um) conuiuentium, Bodero Sdublegino, h(eres) ami(co) s(uo) plu(s) min(us) an(n)orum XLV

Aos deuses Manes. Cornélio Materno, cidadão vadiniense, erigiu (este) monumento, a mando (ou por recomendação, ou por decisão) dos seus concidadãos, a Bodero Sdublegino, de quem ficou herdeiro. Ao seu amigo, de (ou falecido com) cerca de 45 anos.

Se interpretamos correctamente o pensamento de $\mathrm{M}^{\mathrm{a}}$. Cruz González Rodríguez, os conviventes seriam todos os Vadinienses. É certo que as expressões usadas pela autora (1997: 109-111) nos podem deixar dúvidas sobre o seu entendimento da extensão do "cuerpo ciudadano" ou dos "conciudadanos" em nome dos quais Cornélio Materno teria actuado para dar sepultura a Bodero Sdublegino. Sem pretendermos desvirtuar o pensamento de Ma. Cruz González Rodríguez, parece-nos, todavia, que a sua proposta é a de tomar os conviventes como todos os cives Vadinienses. Se assim é, devemos perguntar-nos se todos os cives do território vadiniense (qualquer que seja o sentido exacto de cives neste contexto) terão estado envolvidos na sepultação de Bodero. Será isso credível?

Se imaginarmos a morte ocorrida numa determinada aldeia ou vicus, os conviventes seriam os habitantes desse povoado, em nome dos quais Cornélio Materno, talvez figura proeminente do lugar e herdeiro 
de Bodero, teria actuado. A restituição h(eredes) por h(eres) poderá também ser considerada (caso em que Bodero teria deixado seus bens ao colectivo do povoado). Mas a frequência com que, em sociedades tradicionais, o "estrangeiro" é acolhido pela família dominante do povoado permite pensar que Boderus Sdubleginus terá tido especiais relações com Cornélio Materno, se este era, efectivamente, figura grada do lugar.

A hipótese de uma aldeia ou de um vicus em Pedrosa del Rey não pode, porém, ser aceite sem reservas, uma vez que, na mesma localidade, parece ter aparecido apenas uma outra inscrição, consagrada a um Tedus Vicanus (GonZÁlez RodRíGueZ, 1997: 96 = ERPL, n. ${ }^{\circ} 390$ ).

Talvez não seja improvável que estas duas inscrições tenham vindo de um povoado romano nas imediações de Riaño, povoado do qual proviriam também as lápides funerárias de um Boderus, Pentiocum, de um Turantus, Pentiocum, de um Cadus, Cadarigum e, eventualmente, também a de um Terentius Avitus (ERPL, n. ${ }^{\circ}$ s 364, 392, 367 e 235, respectivamente). A Noroeste de Riaño "quedan vestígios de un posible castro y de una torre de aspecto medieval" (RABANAL AlONSO e GARCÍA MARTíneZ, 2001: 395-396). Será a este castro que se referem J. Mangas e J. Vidal (citados por SASTRE Prats, 2001: 156)?

Teríamos, assim, mais um povoado dos Vadinienses. As distâncias a que se encontram Crémenes, Liegos e Riaño não excluem tal hipótese, dado que, para os transportes da época, oito milhas romanas (isto é, doze quilómetros) exigiriam uma muda de cavalos (para os veículos de passageiros). Por estes povoados poderia seguir uma estrada ao longo do rio Esla, estrada que passaria, a Noroeste de Liegos, por La Uña e Puerto de Tarna.

Ainda que em Riaño ou nas imediações tenha havido um povoado, não é ainda aqui que podemos resolver o problema da natureza das "unidades organizativas" vadinienses designadas por genitivos do plural. Adiando, uma vez mais, uma proposta quanto à natureza dessas "unidades", consideraremos outro aspecto da inscrição de Bodero Sdublegino: o uso do termo amicus.

Mª . Cruz González Rodríguez (1997: 111-117) escreveu, sobre o sentido daquele termo, tão frequente nas inscrições vadinienses, algumas páginas que, muito dignas de ponderação, talvez não excluam outras possíveis interpretações.

A amicitia seria, para esta autora, uma relação que uniria grupos de jóvens vadinienses, pertencentes, como vimos, a uma elite social, 
capazes de treinarem cavalos (tão frequentemente representados nas lápides funerárias da civitas), realizarem competições hípicas e mostrarem suas habilidades como cavaleiros.

Não podendo propor, para a representação de cavalos na epigrafia funerária vadiniense, melhor explicação do que aquelas que têm sido dadas (GonZÁlez RodríGueZ, 1997: 114-115; RABANAL Alonso e GARCIA MARTínEZ, 2001: 430-431), não deixaremos de observar que essa representação ocorre mesmo em lápides funerárias de mulheres (como, aliás, Ma․ Cruz González Rodríguez reconhece), pelo que a sua equacionação com uma eventual elite social jóvem treinadora de cavalos não pode deixar de suscitar dúvidas.

Será que o termo amicus, no território vadiniense, se aplicava ao "imigrante", isto é, àquele que, procedente de uma "unidade organizativa", vinha estabelecer-se na aldeia ou vicus onde tinha(m) residência outra(s) "unidade(s) organizativa(s)"? Estamos a pensar, de novo e obviamente, na possibilidade de entre os Vadinienses existirem gentilitates similares às dos Zoelae e de uma aldeia corresponder a uma gentilitas ou de numa aldeia conviverem duas gentilitates.

Admitindo um povoado em Riaño ou nas imediações, ao qual pertenceriam todas as inscrições mencionadas neste apartado, teríamos Pentioci e Cadarigi nesse povoado? Em tal caso, Bodero, procedente doutro lugar, teria vindo estabelecer-se nessa aldeia ou vicus. Seria um "imigrante" que a população local teria acolhido. Por morte de Bodero, todos os vizinhos da aldeia ou vicus, isto é, os conviventes, ter-se-iam associado para lhe dar sepultura, embora Cornélio Materno, eventualmente como herdeiro, tivesse sido o executor da homenagem fúnebre.

Uma inscrição do castro de Rubiás (Bande, Orense), onde se regista o termo amicus, poderá ser interpretável da mesma forma. Diz a lápide: Medamus, Arcisi f(ilius), hic situs est castello Meidunio. Моnиmentum fecerunt Ancondei amico caro (CIL II 2520).

Medamus seria um imigrante. A ausência de indicação de populus poderá interpretar-se no sentido de que era oriundo de outro castellum que não o Meidunium mas situado no âmbito do mesmo populus. Os Ancondei seriam uma família (ou domus) do castellum Meidunium com a qual Medamus teria tido particulares relações. Se acaso se pode falar de relações de clientela, tanto é admissível a hipótese de os Ancondei terem sido clientes de Medamus (Sastre Prats e Plácido Suárez, 1999:299), como o inverso. 
Voltando ainda às inscrições do hipotético povoado de Riaño, o facto de a inscrição ERPL, n. $^{\circ} 364$ ser dedicada a um [Bo]d[ero] Pent[i]ocum por um Arenus, Andoti (filius), ao am(ico), obrigar-nos-ia a concluir que os Pentioci seriam, nesse povoado, também "imigrantes". Ou poderemos propor outro sentido para o termo amicus?

\subsection{Os amici nas inscrições das granjas}

Se o termo amicus poderá significar o "imigrante" acolhido pela população de uma aldeia ou vicus, não será esse o único sentido que a palavra poderá ter na epigrafia funerária vadiniense.

As inscrições vadinienses que presumimos correspondam a modestas villae ou granjas (por serem achados únicos nos respectivos lugares) e que contêm o termo amicus são as que constam da lista seguinte (onde os números se reportam ao corpus de ERPL). Reproduzimos apenas o essencial dos textos e não cuidamos de anotar as letras restituídas (por ser, para o nosso fim, pouco ou nada relevante essa indicação).

\section{Aleje. [...] amico suo, Balaeso, Frontoni (filio)}

363. Carande. Pentovius Petronius, amico suo Bodero Materno, Bodi fil(io), Vad., an. XX

373. La Velilla de Valdoré. Doidero, Araun, Boderi f(ilio), an. XXX. Turanio, Bodoecum, amico suo

376. La Puerta. Elanio, Veliagum, filius Paterni, an. XXX. Tridalius, amico suo

383. A sul de Liegos. Neconi, Boddegun, Loancinis fili(i), Va. an. XX. Aurelius Proculus, amico suo

388. Santa Olaja de la Varga. Pentovio Blaeso, ann. XXV. Elanus Argaelus, amico

391. Villayandre. Tridio Alongun, Boderi f(ilio), an. XXV. Fronto, Doiderigum, amico suo

395. Remolina. Vadone Biracidegino, Anemidi f(ilio), Vad., an. XXX. Lugua, Caddecum, amico suo

Não deixa de ser digno de registo o facto de a expressão amicus se não encontrar na parte setentrional do território vadiniense.

Parece-nos possível admitir que estas relações de amicitia correspondam a parcerias ou sociedades estabelecidas entre dois indivíduos 
que, juntando esforços e bens, tenham, de comum acordo, instalado uma granja em regime de copropriedade. As idades indicadas, todas entre 20 e 30 anos, obrigam a admitir que, nestes casos, um dos societários morreu novo. Aqui, deparamos com uma primeira objecção possível à nossa hipótese: por que razão não temos, nas granjas, casos de amici falecidos com 40, 50 ou 60 anos?

A esta objecção poderemos responder imaginando que os societários falecidos com 20, 25 ou 30 anos não teriam ainda filhos em idade de lhes tratarem dos funerais, tendo estes ficado, assim, a cargo do outro societário. Nos casos em que um dos societários vivia o tempo suficiente para ver os filhos crescidos, a lápide funerária ser-lhe-ia posta por um filho e não pelo outro societário ou amicus.

Uma segunda objecção não pode deixar de ser feita: não seria natural encontrarmos, nessas granjas, duas inscrições funerárias, uma de cada societário, para marcar a co-propriedade? Assim, no caso de Carande (ERPL, n. $\left.{ }^{\circ} 363\right)$, se Boderus Maternus morreu primeiro, eventualmente deixando filhos pequenos que não podiam ainda tratar-lhe do funeral (ou, não tendo, mesmo, deixado descendência), razão pela qual Pentovius Petronius terá assumido esse encargo, não deveríamos ter outra inscrição ( a de Pentovius Petronius, que lhe sobreviveu), posta por algum filho deste mesmo Pentovius?

$\mathrm{O}$ facto de a inscrição conter não só o nome do dedicado, como o do dedicante, declarados amici, tornaria claro, para os seus contemporâneos, que a granja era pertença dos dois. Assim, imaginando um visitante que, aproximando-se da granja de Carande, entrasse por onde visse, em primeiro lugar, a necrópole, podemos pensar que deduziria, sem necessidade de explicações, que a propriedade era de Pentovius Petronius (ou dos seus descendentes) e dos descendentes de Boderus Maternus.

Poderá achar-se que estas nossas respostas às nossas próprias objecções relevam de uma imaginação pouco credível. Mas não estaremos nós, afinal, apenas a dotar de significado, para os homens contemporâneos das epígrafes, inscrições que um epigrafista presentemente analisa de fora, sem as colocar no contexto e sem imaginar como é que elas seriam lidas, no passado?

No caso de Aleje, para além da inscrição citada, posta a Balaeso, encontrou-se outra no mesmo lugar. Trata-se do epitáfio de Pentius, filho de Balaesus, posto por Viamus, filho de Alisstegianus (ERPL, n. ${ }^{\circ}$ 386). Só muito hipoteticamente podemos admitir que Viamus (ou 
seu pai Alisstegianus) foi quem sepultou Balaesus e que Pentius era filho deste mesmo Balaesus.

Ainda antes de deixarmos a análise das epígrafes aqui coligidas, diremos que não nos parece impossível uma relação familiar entre os amici; nesse caso, porém, seria uma relação distante, para a qual não haveria termo designativo, isto é, um dos amici não seria pater, filius, frater, avus, nepos, proavus, pronepos, avunculus, sobrinus, consobrinus de outro.

A expressão de Cícero, Part. 66, amicos cognatis anteferre deve interpretar-se no sentido de poder existir mais amizade por alguém que não seja da família que entre familiares. Mas não parece excluir a possibilidade de o amicus ser eventualmente um familiar distante.

Também poderá não ser rejeitável a ideia de, em alguns casos, ter havido qualquer forma de adoptio. Assim, por exemplo, o Boderus Maternus de Carande poderia ter sido adoptado por Pentovius Petronius. Ou, no caso de Neconus, o adoptado, Aurelius Proculus, poderia tê-lo sido, não por Neconus, mas pelo pai deste, Loancinus. A hipotética adopção para este segundo caso levanta todavia uma objecção: se a granja foi de Loancinus, e se Aurelius Proculus foi adoptado por aquele, por que razão Loancinus não recebeu lápide funerária posta pelo seu filho Neconus? Se é verdade que, em muitas villae da Península Ibérica, as inscrições funerárias nem sempre terão sido postas ao fundador da villa, mas, muitas vezes, a um seu descendente, de geração eventualmente já afastada da do fundador, o caso de Neconus não é muito facilmente explicável por uma adoptio. Se esta pode ter ocorrido nalguns dos casos vadinienses que aqui registámos, a explicação não servirá para todos.

Nesta cadeia de congeminações, também poderíamos admitir que a amicitia corresponderia à relação entre o proprietário de uma granja e um indivíduo que esse proprietário receberia em sua casa, sem lhe dar copropriedade, mas tratando-o como familiar (ou melhor, como amicus). Neste caso, podemos admitir que o advindo traria alguns bens. A relação poderia não corresponder exactamente à adoptio romana nem à profiliatio que, a partir do séc. IX, se observa na área das Astúrias. A profiliatio consistia na entrada de um indivíduo na clientela ou protecção de outro, mediante a aceitação deste outro como co-herdeiro dos bens do primeiro, que reconhecia ao donatário os mesmos direitos de herança que teriam seus próprios filhos (os do doador) (BARBERO e VIGIL, 1979: 381-394, que vêem na profiliatio "un elemento más que 
prueba la supervivencia de una sociedad gentilicia y su transformación en una sociedad feudal").

A ideia de sociedades ou parcerias realizadas no momento da fundação das granjas (ou em momento posterior) não tem, infelizmente, no território vadiniense, confirmação através da estrutura arquitectónica das granjas, visto que nenhuma das instalações rurais aqui sugeridas foi objecto de clara identificação e escavação. Fora da civitas Vadiniensis, na área de Gijón, o caso de Las Murias de Beloño (JoRdá CERdÁ, 1957), não pode, porém, deixar de merecer a nossa atenção.

Se o edifício do sector C de Las Murias de Beloño (vid. nossa est. VII) corresponde, claramente, a umas termas, não parece fácil interpretar os dois sectores A e B, como uma pars rustica e uma pars urbana, respectivamente: ambas parecem residências de proprietários. A menos que uma delas tenha sido construída ao mesmo tempo que a outra foi abandonada (o que a escavação não sugeriu), não deveremos ver, nos dois edifícios, duas residências de duas famílias unidas por laços de sangue ou de amicitia?

A torre do edifício A, interpretada como ergastula, horreum ou torreão militar, não parece ter servido a nenhum desses fins. Imaginamos antes uma torre eventualmente servindo de sala de recepção a um dos proprietários, que seria o principal administrador do fundus.

$\mathrm{Na}$ Bretanha romana, são numerosos os casos de villae que integram, um a par com outro, dois edifícios residenciais, ou que, apresentando um único edifício como pars urbana, parecem revelar, pela compartimentação interna deste e pelos espaços de circulação, a coexistência de duas famílias. Naquela província, têm-se todavia interpretado tais casos como residências de duas famílias que, estreitamente aparentadas, mantinham alguma autonomia e intimidade próprias (SMITH, 1987: 275-277). Em tais villae viveriam kin-groups, que incluiriam duas famílias conjugais, eventualmente com parentes comuns solteiros ou de idade avançada. J. T. SMITH acrescenta: "It need not be assumed that all the families, at any stage in the kin-group's existence, were of exactly equal status. They could be but commonly were not, and the senior member of the group, or of its leading family, was the recognised head of the kin-group for the time being".

As sociedades que presumimos na exploração das granjas poderiam ser a excepção, e não a regra, como parece dever deduzir-se de diversas inscrições postas por familiares e não por amici. 
Em Vega de Monasterio (ERPL, n. ${ }^{\circ}$ 360), um Arrenus, [Al]iomigu(n), sepultou seu pai, Manilius. A menos que se admita uma "herança" do nome Aliomigi por via feminina, Manilius pertenceria também aos Aliomigi.

Em Sorriba (ERPL n. $\left.^{\circ} 362\right)$, um Doiderus dedicou ao seu filho Boderus, Bodives (cum), falecido com 25 anos (GonZÁLEZ RodRíGUEZ, 1986: C. 57).

Em Argovejo (ERPL, n. $\left.{ }^{\circ} 393\right)$, um Doiderus pôs o epitáfio a seu pai, [T] urennus, [B]oddegun, filho de [B]oddus, falecido com 30 anos. A inscrição não deixa de surpreender pela idade do pai, que pressupõe, tratando-lhe do funeral, um filho muito novo. Mas não é impossível que a idade esteja incorrecta ou aproximada e que, na realidade, Turennus não tivesse exactamente 30 anos, mas andasse na casa dos 30 . A coincidência do nome do pai de Turennus com o nome da "unidade organizativa" (Boddus, Boddegun) leva-nos a perguntar se não poderemos assistir aqui à emergência de um dos genitivos do plural. Assim, teríamos um Boddus que, eventualmente sem nome familiar, teria fundado uma villa ou granja e acumulado riqueza e prestígio suficientes para que seu filho, Turennus, se pudesse arrogar um nome familiar, o de Boddegi. Estamos a pensar, naturalmente, na hipótese, anteriormente posta, de os genitivos do plural vadinienses corresponderem a famílias de particular status. Não podemos, porém, esquecer que este genitivo Boddegun poderia ter uma origem muito mais distante no tempo.

Em Sabero (ERPL, n. $\left.^{\circ} 358\right)$, um Lepidus dedicou a lápide funerária ao seu neto Lucius Antonius, filho de Aquilus, falecido com 20 anos. Ignoramos se Aquilus era já falecido, ou se, mesmo sendo vivo, foi o avô que tratou do funeral por ser o proprietário da granja e sénior da família. Admitindo que Aquilus era ainda vivo, e que Lepidus havia sido o fundador da granja, a "consagração" da necrópole teria sido feita através da lápide a um neto do fundador, e não através de "memória" posta ao fundador, pelo facto de Lucius Antonius ter sido o primeiro (varão) falecido na granja instalada por Lepidus.

Em Villapadierna (ERPL, n. $\left.^{\circ} 396\right)$, um Cangilus dedicou a lápide funerária ao seu avunculus, Vironus, filho de Segisamus. Na granja de um Segisamus (fundada, ou não, por ele), teriam vivido seu filho Vironus e uma irmã deste. Pelo facto de Vironus ter ficado solteiro ou não ter tido descendência, ou por qualquer regra de herança por via feminina, a propriedade teria passado para a filha de Segisamus e desta, para o seu filho Cangilus (neto, portanto, de Segisamus). A morte da mãe de 
Cangilus à data do falecimento de Vironus não tem de, necessariamente, admitir-se. O facto de o possível fundador, Segisamus, ter sido sepultado sem lápide funerária, não é mais surpreendente que o de muitas villae, por toda a Península Ibérica, em que as lápides, seguramente, não se reportam ao primeiro proprietário dessas villae.

Poderíamos prosseguir a análise, caso a caso, das inscrições que, pela sua unicidade, presumimos possam corresponder a granjas. As que acabámos de analisar são, porém, suficientes para sustentarmos a ideia de que as "sociedades" anteriormente supostas poderão ter constituído a excepção.

10.6. Os genitivos do plural vadinienses seriam gentilícios de famílias "nobres"?

As páginas que até agora escrevemos sobre os genitivos do plural vadinienses ainda não nos permitiram responder, de forma minimamente convincente, à pergunta: a que é que correspondem tais genitivos? Trata-se de uma vexata quaestio difícil de solucionar.

A hipótese de se tratar de gentilitates similares às dos Zoelae não parece fácil de aceitar. Primeiro, porque seria muito elevado o número de tais unidades num espaço geográfico reduzido como é o vale de Esla. Segundo, porque seria surpreendente termos, para cada gentilitas, apenas uma atestação epigráfica: que status teria, na gentilitas, o único indivíduo sepultado com menção da sua "unidade organizativa"?

Não nos parece que deva excluir-se liminarmente a hipótese de serem famílias de mais elevado status sócio-económico aquelas que se designam por genitivos do plural. A gente mais comum seria identificada, nas fórmulas funerárias, como Gaius, filho de Gaius (ou pai, ou irmão de Gaius). Os mais importantes usariam um nome de família, um gentilício - e os genitivos do plural seriam tais gentilícios.

Sem querermos deduzir o antes, do depois (o que é sempre perigoso), não podemos deixar de recordar o que a Crónica Rotense (GoMEZ-MoRENO, 1932: 56) diz a propósito da "aclamação" do primeiro rei das Astúrias, Pelaio:

Ille quidem montana petens quantiscumque ad concilium properantes inuenit secum adjuncxit [...]. Qui per omnes astores 
mandatum dirigens in unum collecti sunt et sibi Pelagium principem elegerunt.

"Dirigindo-se ele (Pelágio) para as montanhas, juntou consigo todos quantos encontrou e se encaminhavam para o concílio. Os que, mandato de todos os Ástures, eram os chefes (da região) reuniram-se e elegeram Pelágio para (seu) príncipe”.

Teríamos assim, em 718, no âmbito geográfico do que na Alta Idade Média se chamava Astúrias (e que incluía o antigo território dos Vadinienses), um grupo de "nobres" que se reuniam em assembleia ou conselho. É certo que essa organização poderá ter tido origem apenas no Baixo Império, ou mesmo só no período em que os Visigodos dominaram a Península Ibérica. A ideia de que, neste período (o dos Visigodos), o antigo território cântabro sofreu pequena ou nenhuma evolução, do ponto de vista sociopolítico, é verosímil mas não pode considerar-se suficientemente provada. Liga-se esta hipótese à debatida questão de um possível limes, instalado no Baixo Império e mantido na época visigótica, para norte do qual os Cântabros teriam ficado independentes ou subtraídos ao domínio romano nos últimos tempos do Império e ao da monarquia visigótica (BARBERO e VIGIL, 1979: 217 e 1974: 13-21).

A existência deste limes é controversa (LE Roux, 1982: 393-398; Novo GüISÁN, 1992: 53-58), mas um corpo de tropas estaria estabelecido na cidade cântabra de Iuliobriga, donde, possivelmente, se divulgou a era consular adoptada em algumas inscrições da Cantábria (sobre a era, vid. IGLESIAS e Ruíz, 1998: 169-170 e ABASCAL, 2000-2001).

Voltando aos genitivos do plural vadinienses, a civitas romana de Vadinia não parece que possa ter funcionado sem qualquer assembleia mais ou menos similar a uma ordo decurionum. Daí a nossa proposta (ou hipótese) de ver, nos genitivos do plural vadinienses, os gentilícios ou designativos das famílias principais da civitas romana.

10.7. Os genitivos do plural vadinienses e as "comunidades de vale" medievais

No início destas nossas páginas sobre os genitivos do plural vadinienses, perguntámo-nos se tais genitivos poderiam ter designado grupos sociais com alguma semelhança com as "comunidades de vale" medievais da Cantábria, documentalmente atestadas desde o séc. IX. 
Vários autores têm proposto a radicação das "comunidades de vale" nas "unidades organizativas" vadinienses de época romana que teriam, por seu turno, origem pré-romana. Nós mesmos, sem a termos examinado detidamente, considerámos verosímil tal hipótese (ALARCÃO, 1991(1): 143-144), que, todavia, agora nos parece algo duvidosa.

"O vale, consolidado como unidade espacial configurada por um meio físico determinante, que pode, por vezes, coincidir com um vale geográfico ou uma depressão, ... [é] um âmbito, relativamente extenso, que inclui vários lugares ou aldeias, os quais formavam um agrupamento claramente definido... [que constituía] o espaço vital, o marco de vida da comunidade [que o habitava e explorava], comunidade que [tinha] clara consciência da sua pertença a esse espaço e se [identificava] com ele... A demarcação da unidade de vale na Cantábria surge a partir do contexto gentilício, dado que foi o primitivo carácter desse modelo de sociedade que elegeu, se adaptou e determinou essa concepção territorial" (DíEz HerRERA, 1990: 25-26, com parênteses rectos nossos onde alterámos a morfologia ou sintaxe sem viciarmos o sentido do texto; vid., sobre as comunidades de vale, também MARTín VISO, 1993: 37).

A ideia de que a "comunidade de vale" medieval, pré-feudal, da Cantábria poderia ter a sua origem nas "unidades organizativas" de época romana designadas por genitivos do plural foi defendida por A. Barbero e M. Vigil (1971: 214-216), que tomaram essas unidades como clãs. Tais clãs, segundo esses dois autores, praticariam uma agricultura nómada associada ao pastoreio e deslocar-se-iam num "território bastante extenso, com certa unidade geográfica, como são os vales dos rios".

Não voltaremos aqui às nossas dúvidas sobre a "agricultura nómada" dos Vadinienses. Mas a observação do vale do rio Esla, entre os paralelos de Liegos e Barniedo, a norte e Aleje, a sul, parece-nos tornar pouco aceitável a hipótese de os genitivos do plural vadinienses designarem "comunidades de vale", clãs ou gentilitates.

Com efeito, no vale do Esla, entre aqueles dois paralelos, isto é, numa extensão de quase 25 quilómetros (seguindo as curvas do rio), as inscrições funerárias de época romana registam 13 diferentes genitivos do plural. Isto significaria, para cada comunidade, em média, cerca de 2 quilómetros de vale. Mesmo admitindo que territórios limitados, no sentido do eixo do vale, poderiam ser compensados pela extensão em largura ou, por outras palavras, que uma comunidade explorava um troço do vale e as correspondentes encostas e cumes dos montes que o delimitavam, o território parece-nos diminuto para uma gentilitas ou clã territorial. 
A oriente da aldeia ou vicus de Crémenes, parece-nos deverem identificar-se como villae ou granjas os sítios de La Remolina, Argovejo e Villayandre.

Em La Remolina, como vimos, um Lugua, Caddecun, consagrou a lápide funerária amico suo, Vadone Biracidegino (ERPL, n. $\left.{ }^{\circ} 395\right) . \mathrm{M}^{\mathrm{a}}$. Cruz González Rodríguez atribui ao mesmo lugar a inscrição de Fronto, Doiderigum, ao amico suo, Tridio, Alongun; mas ERPL, n. ${ }^{\circ} 391$, dá esta epígrafe como procedente de Villayandre.

Em Argovejo, um Doiderus dedicou a lápide a seu pai, Turenno, Boddegun (ERPL, n. $\left.{ }^{\circ} 393\right)$.

A distância de La Remolina a Villayandre é de 6.800 m. Não parece muito credível que um clã ou comunidade de vale (admitindo que os genitivos do plural representassem tais unidades) ocupasse pouco mais de 2 quilómetros. Além disso, a presença de dois genitivos do plural em Villayandre obrigaria (em tal caso) a admitir a coexistência de dois clãs (ou duas comunidades de vale) no mesmo espaço.

As nossas dúvidas, porém, carecem de mais atento exame, sobre cartas geográficas mais detalhadas do que as da escala 1:200.000 de que, neste momento, nos podemos servir. Talvez a ideia de que os genitivos do plural, entre os Vadinienses, designam famílias de "nobres" não exclua necessariamente a de comunidades de vale. Com efeito, poderemos admitir que, da sua granja, uma família "nobre" dominaria uma população dispersa por casais ou mesmo concentrada em dois ou três castella, ou duas ou três aldeias. Neste caso, o genitivo do plural designaria a família dominante mas talvez não as famílias dominadas. Parece-nos algo remota (ainda que não liminarmente rejeitável) a possibilidade de os "dominados" se considerarem aparentados com a família "dominante" através de um antepassado mítico. Mas uma certa forma de "campesinato", com uma classe de rurais que, sem título de propriedade, explorariam as terras dos "nobres", não é hipótese que deva rejeitar-se (SASTRE PRATS, 2001:161 s.).

\subsection{O caso de Valmartino}

Nas faldas de Peñacorada, no "termino" de Valmartino, foi encontrada a seguinte inscrição: Doviderus, Amparami f(ilius), princeps Cantabrorum, $h($ ic) $s($ itus $)$ e(st). Deobrigi f. p(osuerunt) (ERPL, n. $\left.{ }^{\circ} 374\right)$. 
Júlio Mangas e David Martino (1997) discutiram longamente o sentido de Deobrigi e do $f$. que segue este nome, bem como o estatuto deste princeps Cantabrorum. Quanto ao $f$., não se decidiram entre $f$ (ilii) e $f($ ecerunt $)$.

A leitura $f($ ecerunt $)$ parece-nos preferível a $f(i l l i)$. Teríamos, assim, um povoado Deobriga, cujos habitantes, Deobrigi (por Deobrigenses), teriam consagrado a lápide a Doviderus. A existência de uma Deobriga entre os Autrigones e de uma Deobrigula entre os Murgobi (Ptolemeu, II, 6, 52 e II, 6, 51) viabiliza o topónimo, que se repetiria, portanto, no norte da Península. Também havia uma Deobriga entre os Vetões (Ptolemeu, II, 5, 7).

O título de princeps Cantabrorum suscita maiores dúvidas. Júlio Mangas e David Martino perguntaram-se se seria um príncipe de todos os Cântabros e concluíram: "no vemos razones políticas para sostener nada semejante" (1997: 333). Prosseguindo a análise, acabaram por admitir tratar-se de um "príncipe de un ámbito reducido de los cántabros" (1997: 338-339).

A atribuição da inscrição de Valmartino ao séc. I d.C., antes dos seus finais, parece aceitável, ainda que a ausência da fórmula Dis Manibus ou Dis Manibus Sacrum não possa ser argumento decisivo, dada a raridade desta fórmula na epigrafia vadiniense, mesmo dos séculos II e III d.C.. A nós, que temos sustentado uma organização político-administrativa sui generis do Noroeste peninsular antes dos Flávios, com principes a governarem os populi que só depois da concessão do ius Latii teriam sido convertidos em verdadeiras civitates (AlARCÃO, 1988, vol. I: 31 e AlARCÃo, n.p.), a existência de um princeps na Cantábria não surpreende. Mas surpreende a existência eventual de um princeps de todos os Cântabros.

Se Doviderus tivesse sido princeps dos Vadinienses, a par com outros príncipes dos outros populi da Cantábria, a inscrição devia conter a expressão princeps Vadiniorum ou Vadiniensium. A expressão princeps Cantabrorum poderá entender-se no quadro de uma ou outra das seguintes hipotéticas situações:

1. Os diversos populi cântabros teriam, cada um, seu princeps. Todos os príncipes integrariam um concilium que escolheria (com alguma intervenção da autoridade romana) um presidente ou sénior ao qual seria dado o título de princeps Cantabrorum. Neste caso, Doviderus teria sido princeps Vadiniorum mas achar-se-ia investido, na altura da sua morte, no cargo de princeps Cantabro- 
rum. Ou teria sido, em algum tempo, o sénior do suposto concilium. Como tal teria sido recordado na lápide funerária.

2. Não haveria um, mas vários principes por cada populus, e todos eles receberiam o título de princeps Cantabrorum.

3. Doviderus teria sido princeps de todos os Cantabri (GoNZÁLEZ RODRIGUÉZ, 2002)

Preferindo a primeira hipótese, podemos admitir que Doviderus, princeps Vadiniorum com desempenho vitalício ou hereditário, e tendo exercido, em certo momento, as funções de sénior do concilium, proviria de alguma família particularmente importante, o que sustenta a nossa hipótese (sem que possa ser considerado argumento decisivo) de algumas famílias de maior status entre os Vadinienses, famílias que seriam as que usariam os genitivos do plural em -um.

Em Valmartino achou-se também a inscrição M(onumentum) $D($ is $)$ Ma(nibus) Dovide(rus), Ara(vi) f(ilius), p(osuit) Megalo, Veronigo$r u(m)$, an(norum) $X X V$ (ERPL, $\left.n .^{\circ} 385\right)$. Será que, a certa distância do castellum Deobriga, haveria uma villa ou granja da família dos Veronigi? Seria desta família que teria surgido, no séc. I d.C., o Doviderus que foi princeps Cantabrorum? Infelizmente, a ausência de qualquer laço familiar expresso entre Megalus e Doviderus, Aravi f(ilius), bem como a ausência do termo amicus, impede-nos de conhecer as relações que entre si teriam ou mantiveram dedicado e dedicante desta inscrição de Valmartino, bem como de saber se o princeps Cantabrorum era da família dos Veronigi. Mas, se o fosse, não deveríamos ter, na inscrição, o seguinte texto: Doviderus, Veronigorum, Amparami f(ilius), princeps Cantabrorum? Tendo em atenção que as inscrições dos Vadinienses com genitivos do plural parecem ser, na maioria, dos séculos II e III, poderíamos argumentar que, embora no séc. I houvesse já famílias de maior status, ainda se não teria adoptado a "moda" dos gentilícios para as distinguir. Mas isto é pura especulação.

\subsection{Os genitivos do plural entre os outros Cântabros}

Se os genitivos do plural vadinienses designam famílias "nobres", por que razão são eles tão frequentes entre esses mesmos Vadinienses e tão raros entre os outros Cântabros? Com efeito, Mํㅡ. Cruz González 
Rodriguez (1997: 117) refere que se encontram apenas 3 em Monte Cildá e 7 no resto do território cântabro.

Ainda que seja difícil definir os limites da regio Cantabrorum de Plínio, IV, 34, 111, e identificar os dos populi e/ou das civitates que a integravam, arriscaremos uma proposta (nossa est. VIII), conscientes, todavia, de que não vale mais do que as de outros investigadores espanhóis, que, obviamente muito mais habilitados do que nós, têm manifestado sérias dúvidas e incapacidades (entre eles, SolAna SÁinZ, 1998 e 1998(1); SAntos Yanguas, 1992). Só num cauteloso pouco a pouco, ajudados por inscrições novas que possam surgir, será possível ir esclarecendo a etnogeografia da regio e identificando as civitates, com seus lugares centrais e seus limites.

Recolhendo as informações de autores gregos e latinos (que se encontram registadas em TIR, Hoja K-30: Madrid) e o testemunho das inscrições, identificam-se os seguintes populi:

Avarigini

Blendii

Concani

Coniaci

Conisci

Orgenomesci

Plentusii

Salaeni

Vadinienses

Teríamos, assim, completa a lista dos 9 populi que Plínio, IV, 34, 111 atribui à regio Cantabrorum.

Por outro lado, Ptolemeu, II, 6, 50 atribui aos Cântabros as seguintes cidades:

Argenómescon

Camarica

Iuliobriga

Móroica

Ottaviolca

Vadinia

Vellica

Dado que Mela, 3.15, informa que per Avariginos et Orgenomescos Namnasa descendit, se o rio Namnasa se identificar, como parece, com o actual Nansa, os Avarigini ficariam no curso alto do rio e os 
Orgenomesci, junto do litoral, servidos, como diz Plínio IV, 34, 111, pelo porto de Veseiasueca, talvez em San Vicente de la Barquera.

A existência de um Portus Blendium obriga a situar também os Blendii no litoral, mas não é seguro que o porto corresponda ao actual de Suances.

Mela, 3.15, diz que per [Bl]endi[os] et Salaenos Saunium (SoLANA SÁinZ, 1998(1): 61). Os dois povos ficariam situados de um lado e do outro da ria de San Martín de la Arena, se acaso Saunium corresponde a esta ria. Mas, se Saunium era um rio, os Blendii ficariam a jusante e os Salaeni, a montante desse curso de água, ou a ocidente e a oriente.

Perto dos Berones, segundo Estrabão, 3.4.12, os Conisci devem situar-se no extremo sudeste ou sul da regio Cantabrorum. Poderíamos localizá-los onde, no nosso mapa, colocamos os Concani. Mas, como a capital destes era Concana, e porque não parece haver espaço para instalar Concana entre a civitas Maggaviensium e a provável cidade capital de Camarica, apontamos como possível lugar dos Concani o sudeste da regio Cantabrorum. Localizamos os Conisci a sul e sugerimos a sua identificação com a civitas Maggaviensium. Os Plentusii, citados por Estrabão, 3.3.8, num passo corrupto que não permite assegurar a forma correcta do etnónimo, ficariam algures perto das fontes do Ebro, pelo que não deixa de ser digna de consideração a hipótese de se identificarem com a civitas de Iuliobriga. O Portus Victoriae Iuliobrigensium, na baía de Santander, seria um enclave da civitas em território possivelmente de Salaeni.

A localização dos Vadinienses é, de todas, a mais segura devido às abundantes inscrições funerárias de Vadinienses em seu próprio território.

Ficam, pois, por situar os Coniaci e, das cidades mencionadas por Ptolemeu, devemos agora procurar Camarica, Móroica, Ottauiolca e Vellica.

Reutilizada na parede de um edifício anexo à igreja paroquial de Ruesga (Palência), a inscrição $A E, 1990,559$ revela a localização aproximada da cidade. Diz a epígrafe: Di(is) M(anibus). M(onumentum) posuit Atta Orig(ena), Alionig(um), Acid(ae) Avan(a)e, fil(ia)e suae pientiss(i)m(a)e et suum. Camaric(ae), V Idus Mar(tias), co(n)s(ulatu) CCCLXIIII. Hic sepul(ta) (est). An(norum) XX.

A restituição que tem sido adoptada, suum Camaric(um), não faz sentido. Propomos, por isso, que suum seja erro gramatical por suis. Precedendo a data, Camaric(ae) seria o local do enterramento, ainda que a fórmula, habitual em textos jurídicos, seja estranha em texto fune- 
rário. Camarica ficaria, pois, nas proximidades de Ruesga. É simplesmente hipotética a sua identificação como capital dos Coniaci.

Não temos indícios da localização de Móroica nem sabemos a que populus deve atribuir-se esta cidade. Octaviolca ou Ottaviolca ficaria a sul de Iuliobriga (TIR, Hoja K-30).

A Vellica de Ptolemeu tem sido, por vezes, equacionada com Monte Cildá (Palência). A presença, aqui, de um Val(erius) Quadrat(us), Boddi filius, Vellic(us) (ou Vellicensis) (numa inscrição funerária onde Mª . Cruz González Rodriguez, 1986, C. 201, lê Vellic(um), tomando o nome como genitivo do plural), lança alguma suspeita sobre a identificação: Valerius Quadratus não será um imigrante, vindo de Vellica para Monte Cildá? É possível que Monte Cildá corresponda à Maggava da téssera de Herrera de Pisuerga (Palência), datada de 14 d.C. (GonZÁlez RodrígueZ, 1986: C. 155; HernándeZ Guerra e SAGREDO SAN EuSTÁQUIO, 1998: 108). O território da civitas Maggaviensium viria, a sul, até Herrera de Pisuerga, como parece depreender-se da mesma téssera. Quanto a Vellica, ignoramos não só a sua localização, como também se pertencia a algum dos populi anteriormente citados.

A nossa figura representa os possíveis limites da regio Cantabrorum e a localização dos seus populi e cidades. Para o limite entre os Cântabros e os Vaqueus, adoptámos a proposta de L. Hernández Guerra e L. Sagredo San Eustáquio (1998: 19), que traçam a fronteira por Cistierna, Velilla del Rio Carrión, Quintanilla de Onsoña, Herrera de Pisuerga, Castrillo e Villadiego. Para os mesmos autores, os Cântabros viriam até Olleros de Pisuerga e a fronteira passaria pelo rio Pisuerga ou pelo Burejo.

Assinalámos a área coberta pelo recente corpus epigráfico de J. M. Iglésias e A. Ruíz (1998). Ora, nesta área, conhecem-se apenas 9 inscrições funerárias, das quais 3 ou, possivelmente, 4, registam tais genitivos.

Em Pico Dobra ou Monte Dobra, a oriente de Torrelavega, em território possivelmente de Blendii, numa área onde parecem existir dois castros, o de Sovilla e o de Sopenilla, encontrou-se uma ara ao deus indígena Erudinus, posta por um Corne(lius) Vicanus, Aunigainum. O genitivo do plural tem sido relacionado com o topónimo Ongayo de uma localidade próxima (IGLÉsIAS e RUíz, 1998: 64-68).

Em Luriezo, talvez em território de Avarigini, achou-se uma lápide funerária dedicada por Ambatus e Doiderus ao seu pai, Ambatus Pentoviecus, Ambatiq(um), filho de Pentouius (IGLÉSIAS e RUíz, 1998: 73-74). 
Aos mesmos Avarigini pertenceria Valle de Lamasón, onde um Flavinus dedicou o epitáfio de Aemilius Sempronius, Elesigainum, no ano de 358 da era consular (=320 d.C.?) (IGLÉSIAS e Ruíz, 1998: 80-82).

Numa inscrição de Iuliobriga, infelizmente muito incompleta, lê-se: [...] lic(um) Viami g(ente) monimam(tum?). Com muitas dúvidas, J. M. Iglésias e A. Ruíz (1998: 74-76) propõem o seguinte entendimento: Monumento(?) de [...], dos [...]licos, filho de Viamo.

Feita esta revisão das inscrições com genitivos do plural em -um no território dos Cântabros, não podemos, afinal, estranhar a sua raridade, quando comparada com a abundante ocorrência de tais genitivos entre os Vadinienses: são muito poucas, também, as inscrições funerárias da Cantábria não-vadiniense sem genitivos do plural.

\section{Regresso às gentes dos Luggoni e às gentilitates do conventus Asturum}

No final do nosso apartado 8, perguntámo-nos se as gentes dos Luggoni e as "unidades organizativas" designadas por genitivos do plural presentes no território dos mesmos Luggoni seriam gentilitates ou se aproximariam das "unidades organizativas" dos Vadinienses.

Sustentando a possibilidade de os genitivos do plural vadinienses corresponderem a gentilícios ou nomes de famílias de particular status sócio-económico, não deixaremos agora de admitir que se possam interpretar da mesma forma as gentes e os genitivos do plural dos Luggoni, que confrontavam com os Vadinienses.

A ser assim, as gentilitates do conventus Asturum reduzir-se-iam a:

1. Desonci e Tridiavi da primeira parte do "pacto de Astorga

2. Avolgigi, Visaligi e Cabruagenigi da segunda parte do mesmo pacto (se estas gentes forem interpretadas como gentilitates)

3. Arronidaeci e Coliacini de Serrapio

4. Arnici de Vigo de Sanábria (se gens, aqui, se interpretar também como equivalente de gentilitas)

5. Cognatio Decen(orum) de Aldeia Nova

Se não fosse esta última inscrição de Aldeia Nova, diríamos que as gentilitates não se documentam na epigrafia funerária, mas tão somente 
em inscrições jurídicas ou votivas. Dificilmente, porém, poderemos considerar a inscrição de Aldeia Nova como honorífica, homenageando uma eventual figura grada do lugar.

Seja como for, a epigrafia agora por último compilada não desmente a possibilidade de a gentilitas ser um clã residencial ou um grupo de nós unidos por laços de vizinhança — diferente, pois, dos genitivos do plural dos Cântabros, Luggoni e Vaqueus, que representariam famílias de particular status sócio-económico, e diferentes ainda dos genitivos do plural dos Vetões e Celtiberos, que designariam famílias comuns.

\section{Conclusão}

Não podendo, a partir das epígrafes em que se registam os termos gens, gentilitas e cognatio e daquelas nas quais se observam genitivos do plural em -um ou -orum, deduzir com clareza o significado de tais termos, não deveremos partir da análise da organização social, tal como arqueologicamente parece revelar-se, para entender o que significam tais nomes? Não devemos partir da dimensão das unidades residenciais e dos povoados?

12.1. Não sendo inadmissível a existência, na época pré-romana, de famílias nucleares que habitariam unidades residenciais ou domésticas autónomas e constituiriam unidades de exploração e consumo independentes, comprova-se a existência de famílias alargadas. As famílias alargadas parecem ter sido, pelo menos nalguns casos, constituídas por três gerações vivendo sob o mesmo tecto mas integrariam, ao mesmo tempo, parentes que viveriam em unidades residenciais autónomas. Estas famílias alargadas poderiam ter 25, 30 ou até 50 indivíduos (vid. nosso apartado 6).

Para designar esse tipo de família deveria existir um nome comum. Talvez se usassem, em vez de um, dois nomes: domus (no Noroeste) e cognatio.

12.2. A população de um castro tinha, certamente, um etnónimo próprio (derivado ou não de um topónimo). Mas devia haver um nome comum para designar esse grupo. Era o grupo, muitas vezes, referido, simplesmente, através do termo castellani, como castellani Aiiobrigiaecini. Mas o termo comum gentilitas não designaria o colectivo dos 
habitantes de um castro? A gentilitas Desoncorum do "pacto de Astorga" não seria os todos de um determinado castellum? A gentilitas, nesse caso, designaria um grupo que poderia ter 100, 150 ou $200 \mathrm{mem}$ bros (consideradas as dimensões de grande parte dos castros do Norte e Noroeste peninsulares).

É difícil determinar se tal grupo se consideraria descendente de um putativo antepassado comum, muito distante no tempo - caso em que a gentilitas seria o que poderemos designar por clã.

Castros maiores poderiam alojar duas ou mais gentilitates.

12.3. O termo gens não designaria, em todas as circunstâncias, o mesmo tipo de unidade. Se é óbvio que pode ter o sentido de populus, não parece insustentável que fosse usado no mesmo sentido de gentilitas (tal como definimos em 12.2) ou no mesmo sentido de cognatio (como no caso da gens Gapeticorum de Cáceres).

12.4. O termo cognatio, designando a família alargada, poderia ter, na inscrição de Aldeia Nova (Bragança), o mesmo sentido de gentilitas.

12.5. Os genitivos do plural em -um e -orum seriam gentilícios de famílias alargadas. Mas se, entre Celtiberos e Vetões, a totalidade (ou maior parte) das famílias tinha tais gentilícios, progressivamente substituídos por gentilícios latinos como Valerii, Terentii, Iulii, etc., entre Vaqueus, Cântabros e Ástures Luggoni, tais genitivos terão sido usados apenas por famílias de maior status.

12.6. Estas famílias de maior status, entre os Luggoni, podiam ainda ser designadas pelo nome comum de gentes.

12.7. Não se deve procurar, pois, o que não existiria, isto é, sentidos únicos para os termos gens, gentilitas e cognatio.

\section{REFERÊNCIAS}

AbasCaL, Juan Manuel, 1999: “Apuntes epigráficos" (Mirobriga, Ilici, Jumilla, Segobriga, Saldeana, Carpio del Tajo e Alavera), Archivo Español de Arqueologia, 72: $287-298$

AbASCAL, Juan Manuel, 2000-2001: "La era consular hispana y el final de la práctica epigráfica pagana” Lucentum, 19-20: 269-292 
Abascal Palazón, Juan Manuel, 1994: Los nombres personales en las inscripciones latinas de Hispania, Múrcia

AlarCão, Jorge de, 1988: Roman Portugal, Warminster

AlARCÃO, Jorge de, 1992: “A evolução da cultura castreja”, Conimbriga, 31: 39-71

AlARCÃo, Jorge de, 1996: “As origens do povoamento da região de Viseu”, Conimbriga, 35: 5-35

AlARCÃO, Jorge de, 1999: "Sobre as raízes históricas da paisagem portuguesa", in Raízes greco-latinas da cultura portuguesa (Actas do $1 .{ }^{\circ}$ Congresso da Associação Portuguesa de Estudos Clássicos), Coimbra: 17-32

AlarCÃo, Jorge de, 1999(1): "Populi, castella e gentilitates", in Actas do Congresso de Proto-história europeia (volume especial da Revista de Guimarães), Guimarães, I: $133-150$

AlARCÃo, Jorge de, 2000: A escrita do Tempo e a sua verdade. Ensaios de Epistemologia de Arqueologia, Coimbra

AlARCÃO, Jorge de, 2000(1): “Os nomes de algumas povoações romanas da parte portuguesa da Lusitânia”, in Gorges, J. G. e Nogales Basarate, T. (coord.), Sociedad y cultura en Lusitania romana, Mérida: 165-172

AlARCÃO, Jorge de, 2001: "As paróquias suévicas do território actualmente português", in Villar, F. e Fernández Álvarez, M. P. (eds.), Religión, lengua y cultura prerromanas de Hispania, Salamanca: 29-59

AlARCÃO, Jorge de, n.p.: "As estátuas de guerreiros galaicos como representações de príncipes no contexto da organização político-administrativa do Noroeste pré-flaviano" (a publicar nas actas do colóquio organizado pelo Instituto Arqueológico Alemão, em Lisboa, em 18 e 19 de Janeiro de 2002, sobre "As estátuas de guerreiros lusitano-galaicos")

Albertos Firmat, M‥ Lourdes, 1975: Organizaciones suprafamiliares en la Hispania antigua, Santiago de Compostela/Valladolid

Albertos Firmat, M‥ Lourdes, 1977: "Perduraciones indígenas en la Galicia romana: los castros, las divinidades y las organizaciones gentilicias en la epigrafía”, in Actas del Coloquio Internacional sobre el Bimilenario de Lugo, Lugo: 17-27

Albertos Firmat, M‥ Lourdes, 1981: “Organizaciones suprafamiliares en la Hispania antigua (II). Las gentilitates. Addenda et Corrigenda", Boletín del Seminário de Arte y Arqueologia, 47: 208-214

Alonso Ávila, Ángeles e Ortíz de ZÁrAte, Santos Crespo, 2000: Corpus de inscripciones romanas de la provincia de Zamora. Fuentes epigráficas para la história social de Hispania romana, Valladolid

Álvarez-Sanchís, Jesús R., 1999: Los Vettones, Madrid

Amaral, Paulo, 1993: O povoamento romano no vale superior do Tâmega. Permanências e mutações na humanização de uma paisagem, Porto (tese de mestrado, policopiada, apresentada à Faculdade de Letras do Porto)

ARIAS, Lorenzo, 1993: Prerromanico asturiano. El arte de la monarquía asturiana, Gijón 
Arias Vilas, F.; Le RouX, P.; Tranoy, A., 1979: Inscriptions romaines de la province de Lugo, Paris

Avello Álvarez, J. Luís, 1986: "Panorama arqueológico de los Astures Cismontanos en la actual província de León”, Memorias de Historia Antigua, VII: 7-23

Balil Illana, A. e Martín Valls, R. (eds), 1988: Tessera hospitalis de Montealegre de Campos (Valladolid). Estudio y contexto arqueológico, Valladolid

BARbero, A. e Vigil, M., 1965: "Sobre los orígenes sociales de la Reconquista: Cántabros y Vascones desde fines del Imperio romano hasta la invasión musulmana", Boletín de la Real Academia de la História, 156(2): 271-339

BARbero, A. e Vigil, M., 1971: "La organización social de los cántabros y sus transformaciones en relación con los orígenes de la Reconquista", Hispania Antigua, 1: $197-232$

BARBERo, A. e Vigil, M., 1974: Sobre los orígenes sociales de la Reconquista, Barcelona BARbero, A. e Vigil, M., 1979: La formación del feudalismo en la Península Ibérica, Barcelona

BARJA DE Quiroga, Pedro Lopez, 1999: "El censo provincial, los populi y los castella de Gallaecia", Gallaecia: 347-362

BARKER, Graeme, 1972: "The conditions of cultural and economic growth in the Bronze Age of Central Italy", Proceedings of the Prehistoric Society, 38: 170-208 BARKER, Graeme, 1985: Prehistoric farming in Europe, Cambridge

BARTH, Fredrick, 1981: Selected essays, Londres

BELTRÁN, Francisco, 1988: “Un espejismo historiográfico. Las “organizaciones gentilícias" hispanas", in Actas del Primer Congreso Peninsular de Historia Antigua, II, Santiago de Compostela: 197-237

Beltrán, Francisco, 1994: "Parentesco y sociedad en la Hispania céltica (I a.c. - III d.c.), in GonzÁlez, Ma Cruz e SANTOS, Juan (eds.), Las estruturas sociales indígenas del Norte de la Península Ibérica, Vitória-Gasteiz: 73-104

Beltrán Lloris, F., 1993: "Culto a los Lares y grupos de parentesco en la Hispania indoeuropea”, in MAYER, Marc (ed.), Religio Deorum, Barcelona: 59-71

Bernardo Stempel, P. De, 2000: "Karvo gortika, rita, monima "recuerdo" y los formularios de las inscripciones celtibéricas", Veleia, 17: 183-189

Bourdieu, Pierre, 1994: Le sens pratique, Paris

Bravo, G., 1989: "La entidad de la cognatio y del pacto en un nuevo documento de hospitium entre Amallobrigenses y Caucenses", in Epigrafía Jurídica Romana, Pamplona: 307-323

BúA, Carlos, 1997: "Dialectos indoeuropeos na franxa occidental hispánica", in Galicia fai dous mil anos. O feito diferencial galego. I. História, Santiago de Compostela, 51-99

Burnett, Andrew; Amandry, Michel; RIPOllès, Pere Pau, 1992: Roman Provincial Coinage, vol. I, part I, Londres/Paris

CANTO, Alícia M" , 1990: "La Tabula Lougeiorum: un documento a debate", Cuadernos de Prehistoria y Arqueologia de la Universidad Autónoma de Madrid, 17: 267-275 
Jorge de Alarcão, A Organização Social dos Povos de NW e N da Península 107

Carballo Arceo, Luis Xulio, 1990: "Los castros de la cuenca média del rio Ulla y sus relaciones con el médio físico", Trabajos de Prehistoria, 47: 161-199

CARdozo, Mário, 1972: Catálogo do Museu de Martins Sarmento. Secção de Epigrafia latina e de Escultura antiga, Guimarães

Caro Baroja, Julio, 1976: Los pueblos de España, Madrid

Castellano, A. e Gimeno, 1999: "Tres documentos de hospitium inéditos", in Villar, F. e Beltrán, F., Pueblos, Lenguas y Escrituras en la Hispania prerromana (Actas del VII Coloquio sobre Lenguas y Culturas paleohispánicas), Salamanca: 359-374

Cisneros Cunchillos, Miguel, 1995: "La arqueología de los cántabros: una reflexión metodológica", Zephyrus, 48: 223-234

CostA, Avelino de Jesus da, 1965-1990: Liber Fidei Sanctae Bracarensis Ecclesiae, I, Braga, 1965; II, 1978; III, 1990

Curado, Fernando Patrício, 1988: "Cipo proveniente de S. Estêvão (Sabugal)", Ficheiro Epigráfico, 7, n. $^{\circ} 29$

CURCHIN, Leonard A., 1990: The local magistrates of Roman Spain, Toronto

CRUZ, Carlos Manuel Simões, 2000: A paisagem e o povoamento na longa duração. $O$ Nordeste transmontano - Terra Quente, Braga (dissertação de mestrado, policopiada, apresentada à Universidade do Minho)

DAVID, Pierre, 1947: Études historiques sur la Galice et le Portugal du VI au XII siècle, Lisboa

DiAs, Jorge, 1981 : Vilarinho da Furna. Uma aldeia comunitária, Lisboa

DiAs, Jorge, 1981(1): Rio de Onor. Comunitarismo agro-pastoril, Lisboa

DIAS, Lino Tavares, 1997: Tongobriga, Lisboa

Diego Santos, Francisco, 1959: Epigrafia romana de Astúrias, Oviedo

Diego Santos, Francisco, 1977: Historia de Asturias. 3. Asturias romana y visigoda, Oviedo

Diego SANTOS, Francisco, 1986: Inscripciones romanas de la provincia de León, León

DieZ AsENsio, J., 1991: "Testimonios onomásticos de las organizaciones gentilícias prerromanas en las tierras meridionales del Duero central”, Hispania Antiqua, 15: $17-44$

Diez HERRERA, Cármen, 1990: La formación de la sociedad feudal en Cantabria, Santander Dopico CAínzos, Ma Dolores, 1988: La Tabula Lougeiorum. Estudios sobre la implantación romana en Hispania, Vitória-Gasteiz

ENCARNAÇÃo, José d', 1975: Divindades indígenas sob o domínio romano em Portugal, Lisboa

$E R P L=$ Rabanal Alonso, Manuel Abílio e García Martínez, Sónia María, Epigrafia romana de la província de León: revisión y actualización, León

EsParza Arroyo, Angel, 1983-1984: "Los castros de Zamora occidental y Trás-os-

Montes oriental: habitat y cronologia", Portugalia, nova série, 4-5: 131-146 Esparza ARroyo, Angel, 1986: Los castros de la Edad del Hierro del Noroeste de Zamora, Zamora 
FeRnÁNDEZ-Albalat, Blanca García, 1990: Guerra y religión en la Gallaecia y la Lusitania antiguas, Corunha

FERNÁNDEZ MANZANO, Julio, 1986: "El territorio ástur antes de la llegada de los Romanos", in Actas del I Congreso Internacional Astorga romana, Astorga: 13-36 FERNÁNDEZ Mier, Margarita, 1999: Génesis del territorio en la Edad Media. Arqueología del paisaje y evolución histórica en la montaña asturiana, Oviedo

FERNÁNDEZ-OCHOA, Cármen, 1983-1984: "Poblamiento rural en Asturias durante la epoca romana", Portugália, nova série, 4-5: 231-243

FERnÁNDEZ-OCHOA, Cármen e Morillo Cerdán, Ángel, 1999: La tierra de los Astures. Nuevas perspectivas sobre la implantación romana en la antigua Asturia, Gijón Fernández-OchoA, Cármen e PÉrez Fernández, Daniel, 1990: "Inscripción romana hallada en la muralla de Gijón. Una nueva gens entre los Astures Transmontanos", Cuadernos de Prehistória y Arqueología de la Universidad Autónoma de Madrid, 17: 255-265

FERNÁNDEZ-POSSE, Maㅡ Dolores et alii, 1993: "Espacio y metalurgia en la cultura castreña: la zona arqueológica de las Medulas", Trabajos de Prehistoria, 50: 197-220

FERNÁNDEZ-POSSE, M"a . Dolores et alii, 1994: "Estructura social y territorio en la cultura castreña prerromana”, Trabalhos de Antropologia e Etnologia, 34 (3-4): 191-212

Fernández-Posse, Ma ${ }^{\text {a }}$. Dolores e SÁnChez-PaLEnCia, F. Javier, 1988: La Corona y el Castro de Corporales, II, Madrid

FernándeZ-Posse, Ma. Dolores e SÁnchez-PaLEnCIA, F. Javier, 1998: "Las comunidades campesinas en la cultura castreña", Trabajos de Prehistoria, 55(2): 127-150

ForGE, Anthony, 1972: "Normative factors in the setllement size of Neolithic cultivators (New Guinea)", in UcKo, P. J.; Tringhan, R.: Dimblebry, G. W. (eds.), Man, settlement and urbanism, Londres: 363-376

GHASARIAN, Christian, 1999: Introdução ao estudo do parentesco, Lisboa

GarCía Merino, Cármen, 1972: "Nuevo epígrafe vadiniense, procedente de Carande (León) y el problema de los Vadinienses como grupo de población hispanorromano", Boletín del Seminario de Arte y Arqueologia, 38: 499-511

García Merino, Cármen, 1975: Población y poblamiento en Hispania romana. El conventus cluniensis, Valladolid

GómeZ-Moreno, Manuel, 1932: Las primeras crónicas de la Reconquista. El ciclo de Alfonso III, Madrid

Gómez-PANToJA, Joaquín, 1996: "Gentilidad y orígen”, in Villar, F. e ENCARnaÇão, J. (eds.), La Hispania prerromana. Actas del V Colóquio sobre Lenguas y Culturas prerromanas de la Península Ibérica, Salamanca/Coimbra: 77-100

GonZÁLEZ, Ma . Cruz e SANTOS, Juan, 1984: "La epigrafía del conventus cluniense. I. Las estelas vadinienses", Memórias de História Antigua, 6: 85-107

GonZÁlez, Mạ. Cruz e SANTos, Juan, (eds.), 1994: Las estructuras sociales indígenas del Norte de la Península Ibérica, Vitória-Gasteiz

GonZÁlez RodríGUeZ, M‥ Cruz, 1986: Las unidades organizativas indígenas del area indoeuropea de Hispania, Vitória-Gasteiz 
González Rodríguez, Ma․ Cruz, 1986 (1): “Corpus de inscripciones del área indoeuropeia de la Península Ibérica com mención de unidades sociales indígenas”, Memórias de Historia Antigua, VII: 51-80

GonzÁlez RodríGuEZ, Ma . Cruz, 1994: "Reflexiones sobre las unidades organizativas indígenas del area indoeuropea", in GonzÁlez, M Cruz e SANTOS, Juan, Las estructuras sociales indígenas del Norte de la Península Ibérica, Vitória-Gasteiz GonZÁlez RodríGuez, Ma . Cruz, 1994(1): "Las unidades organizativas indígenas. II. Addenda et corrigenda”, Veleia, 11: 169-175

González Rodríguez, Ma ${ }^{\mathrm{a}}$. Cruz, 1997: Los Ástures y los Cántabros Vadinienses. Problemas y perspectivas de análise de las sociedades indígenas de la Hispánia indoeuropeia, Vitória-Gasteiz

GonzÁlez RodríGuez, Ma . Cruz, 1998: "Las estructuras sociales indígenas entre los pueblos del Norte", in Rodríguez NeILA, J. F., Los pueblos prerromanos del Norte de Hispania. Una transición cultural como debate histórico, Pamplona GonzÁlez RodríGuez, Ma . Cruz, 2002: “Anotaciones sobre las élites indígenas cántabras y su integración por parte de Roma”, in GARCIA Soler, M․ José (ed.), Timês Charin. Homenaje al Professor Pedro A. Gainzarain, Vitória-Gasteiz: 309-318

GonzÁlez Rodríguez, Ma Cruz e SAntos Yanguas, J., 1985-1986: 'El caso de las llamadas gentilitates: revisión y propuestas”, Veleia, 2-3: 373-382

Grau Lobo, Luís e Hoyas, José Luís (eds.), 2001: El bronce de Bembibre, Un edicto del emperador Augusto del año 15 a.C., Valladolid

Guerra, Amílcar Manuel Ribeiro, 1998: Nomes pré-romanos de povos e lugares do ocidente peninsular, Lisboa (tese de doutoramento, policopiada, apresentada à Faculdade de Letras de Lisboa)

Gurvitch, Georges, 1979: A vocação actual da Sociologia, Vol. I, Lisboa

Gurvitch, Georges, 1986: A vocação actual da Sociologia, Vol. II, Lisboa

Hassan, Fekri A., 1982: "Demographic archaeology", in ScHIFFER, Michael B., Advances in archeological method and theory. Selections for students from volumes I through IV, New York: 225-279

HERNÁNDEZ GUERRA, Libório, 1994: Inscripciones romanas en la província de Palencia, Valladolid

Hernández Guerra, Libório e SAGRedo SAn Eustaquio, Luís, 1998: La romanización del territorio de la actual provincía de Palencia, Valladolid

Hurtado de SAN ANTónio, R., 1977: Corpus provincial de inscripciones latinas (Cáceres), Cáceres

Iglesias, José Manuel e Ruíz, Alícia, 1998: Epigrafia romana de Cantábria, Bordéus/Santander

Iglesias GiL, José Manuel, 1974: Onomástica prerromana en la epigrafía cántabra, Santander

JoNES, Siân, 1998: The archaeology of ethnicity. Constructing identities in the past and present, Londres/New York 
JoRdÁ CERDÁ, Francisco, 1957: Las Murias de Beloño (Cenero-Gijón). Una «villa» romana en Asturias, Oviedo

Le Roux, Patrick, 1982: L'armée romaine et l'organisation des provinces ibériques d'Auguste à l'invasion de 409, Paris

Le RouX, Patrick, 1994: "La tessère de Montealegre et l'évolution des communautés indigènes d'Auguste à Hadrien", Klio, 76: 342-354

Le Roux, Patrick, 1995 : Romains d'Espagne. Cité et politique dans les provinces. II siècle av. J.C. - III siècle ap. J.C., Paris

Le Roux, Patrick, 2001: “L'edictum de Paemeiobrigensibus. Un document fabriqué?", Minima Epigraphica et Papyrologica, 4(6): 331-363

Lemos, Francisco de Sande, 1993: Povoamento romano de Trás-os-Montes Oriental, Braga (tese de doutoramento, policopiada, apresentada à Universidade do Minho) Lemos, Francisco de Sande, 1996: "Povoamento, espaço e gentilitates no $1 .^{\circ}$ milénio a.C. no Nordeste transmontano", in AlARCÃo, Jorge (ed.), De Ulisses a Viriato. O 1. ${ }^{\circ}$ milénio a.C., Lisboa: $147-153$

LOMAS, F. J., 1990: "El ordenamiento gentilício, una realidad de los pueblos del Norte", Hispania Antiqua, 14: 159-178

LOMAS, F. J., 1994: "Estructuras de parentesco en la sociedad indígena del Norte peninsular hispánico", in GonZÁLEZ, Mª Cruz e SANTOS, Juan, Las estructuras sociales indígenas del Norte de la Península Ibérica, Vitória-Gasteiz: 117-137

Lomas Salmonte, F. Javier, 1975: Asturia prerromana y altoimperial, Sevilha

Luzón Nogué, J. Mà. e SÁnchez-Palencia, F. J., 1980: El Caurel, Madrid

KARLSSON, Häkan, 1998: Rethinking Archaeology, Goteburgo

KARLSSON, Häkan, 2000: "Why is there material culture rather than nothing? Heideggerian thoughts and Archaeology", in Holtorf, Cornelius e KarLsson, Hälaf, Philosophy and archaeological practice. Perspectives for the $21^{\text {st }}$ century, Goteburgo: 69-80 MalloRY, J. P. e ADAMS, D. Q., 1997: Encyclopedia of Indo-European Culture, Londres/Chicago

MAÑANES, Tomás, 1981: El Bierzo prerromano y romano, León

MAÑANES, Tomás, 1983-1984: "Protohistoria y romanización en la província de León: habitat y cronologias", Portugália, nova série, 4-5: 151-173

MAÑANES, Tomás e SolANA, José Mª , 1999: Inscripciones de época romana de la província de Valladolid, Valladolid

Mañanes, Tomás e Solana SÁInz, José Má, 1985: Ciudades y vias romanas en la cuenca del Duero (Castilla-León), Valladolid

MaÑAnes PÉRez, Tomás, 2000: Inscripciones latinas de Astorga, Valladolid

Mangas, Júlio e Martino, David, 1997: "Princeps Cantabrorum en una nueva inscripción", Gérion, 15: 321-339

MANGAS, Júlio e Olano, Manuel, 1995: "Nueva inscripción latina. Castella e castellani del área astur", Gérion, 13: 339-347

MARTín VALls, Ricardo, 1973: "Notas sobre la epigrafía romana de Yecla de Yeltes (Salamanca)", Durius, I: 37-43 
Martín VAlls, Ricardo, 1979: "Novedades epigráficas del castro de Yecla de Yeltes (Salamanca)", in Estudios dedicados a Callejo Serrano, Cáceres: 499-510

Martín VAlls, Ricardo, 1982: "Las necrópolis del castro de Yecla de Yeltes. Datos arqueológicos y epigráficos para su estudio", Zephyrus, 34-35: 181-201

MARTín Viso, Iñaki, 1993: "La feudalización del valle de Sanabria (siglos X-XIII)", Studia Historica - História Medieval, 11: 35-55

MARTINs, Manuela, 1990: O povoamento proto-histórico e a romanização da bacia do curso médio do Cavado, Braga

MAya GonZÁleZ, José Luís, 1983-1984: "Habitat y cronologia de la cultura castreña en Asturias”, Portugália, nova série, 4-5: 175-198

Maya GonzÁlez, José Luís, 1989: Los castros en Astúrias, Gijón

MENENDES BuEYes, Luís Ramón, 2001: Reflexiones críticas sobre el orígen del reino de Astúrias, Salamanca

Montenegro DuQue, Ángel, 1992: "Precisiones sobre la transcripción e interpretación de la tessera hospitalis de Montealegre", Hispania Antiqua, 16: 201-221

NAROLL, Raoul, 1962: "Floor area and settlement population", American Antiquity, 27(4): 587-589

Novo GüsIAn, José Miguel, 1992: Los pueblos vasco-cantábricos y galaicos en la Antegüedad tardía. Siglos III-IX, Alcalá de Henares

Oliverra, Américo e Silva, Filomeno, 2000: Montemuro. A última rota da transumância, Arouca

Orejas Saco Del Valle, Almudena, 1996: Estructura social y território. El impacto romano en la cuenca noroccidental del Duero, Madrid

Orejas, Almudena e SÁnchez-PALENCIA, 1999: "Arqueologia de la conquista del Noroeste de la Península Ibérica”, in Balbín Behrmann, R. e Bueno Ramírez, P. (eds.), II Congresso de Arqueologia Peninsular, tomo IV, Arqueologia romana y medieval, Alcalá: 23-37

Peralta Labrador, Eduardo, 1993: "La tessera cántabra de Monte Cildá (Olleros de Pisuerga, Palencia)", Complutum, 4: 223-226

Pereira Menaut, G., 1978: “Caeleo Cadroiolonis f. Cilenus ç Berisamo et al.: centuria or castellum? A discussion”, Hispánia Antiqua, 8: 271-280

Pereira Menaut, G., 1982: "Los castella y las comunidades de Gallaecia”, Zephyrus, 34-35: 249-267

Pereira Menaut, G., 1993: “Cognatio Magilancum. Una forma de organización indígena de la Hispania indoeuropeia”, in Untermann, J. e Villar, Francisco (eds.), Lengua y cultura en la Hispania prerromana (Actas del V Coloquio sobre Lenguas y Culturas prerromanas de la Península Ibérica, Colónia, 1989), Salamanca: 411-424

Pereira Menaut, Gerardo, 1994: “Cognatio Magilancum. A propósito de la investigación sobre las sociedades indígenas del Norte de Hispánia”, in GonZÁLEZ, Ma Cruz e SAntos, Juan (eds.), Las estructuras sociales del Norte de la Península Ibérica, Vitória-Gasteiz: 105-116 
Pereira Menaut, G. e Santos Yanguas, J., 1980: "Sobre la romanización del noroeste de la Península Ibérica: las inscripciones con mención del origo personal", in Actas do Seminário de Arqueologia do Noroeste Peninsular, III, Guimarães: 117$-130$

PRÓSPER, Blanca María, 2002: Lenguas y religiones prerromanas del Occidente de la Península Ibérica, Salamanca

Rabanal Alonso, Manuel Abílio e Garcia Martínez, Sónia Maria, 2001: Epigrafia romana de la província de León: revisión y actualización, León

RADCLIFFE-BRown, A. R. e FordE, Daryll, 1982: Sistemas políticos africanos de parentesco e casamento, Lisboa

Redentor, Armando J. M., 2000: Epigrafia romana da região de Bragança, Coimbra (tese de mestrado, policopiada, apresentada à Faculdade de Letras de Coimbra)

REDONDo RodríGueZ, J. A., 1985: "Restos de una antigua ordenación social y territorial: las gentilidades vettonas en la província de Cáceres: estado de la cuestión", Norba, 6: 29-41

REDONDO RodRíGUEZ, J. A., 1993: “Organizaciones suprafamiliares vetonas”, in El proceso histórico de la Lusitania oriental en época prerromana y romana, Mérida: 37-53

RENFREW, C., 1972: "Patterns of population growth in the prehistoric Aegean", in UCKO, P.; Tringham, R.; Dimbleby (eds.), Man, settlement and urbanism, Londres: 383-399

Ricoeur, Paul, 1995: Teoria da interpretação, Porto

Rios González, Sérgio e Castro Valdés, César García, 2001: "Observaciones en torno al poblamiento castreño de la Edad del Hierro en Asturias", Trabajos de Prehistoria, 58(2): 89-107

RodríGuEZ, Pilar, 1990: "El significado de civitas en Cicerón", Veleia, 7: 233-241 RODRÍGUEZ, Pilar, 1994: "Los términos gens y gentilitas en los escritores latinos", in Rodríguez, M ${ }^{\mathrm{a}}$ Cruz e SANTOS, Juan, Las estructuras sociales indígenas del Norte de la Península Ibérica, Vitória-Gasteiz: 67-71

RodRÍGUEZ, Pilar, 1996: Gens. Una forma de agrupación antigua mal conocida, Vitória Rodríguez Alvarez, Pilar, 1993: "Sobre las gentes de Hispânia", in Untermann, J.

e VILlar, F. (eds), Lengua y cultura en la Hispania prerromana (Actas del $V$ Colóquio sobre Lenguas e Culturas prerromanas de la Península Ibérica), Salamanca: 445-460

Rodríguez Alvarez, Pilar, 1999: "También hay gentilitates fuera de Hispania" in Homenaje a José M. ${ }^{\underline{a}}$ Blázquez (ed. Alvar, Jaime), vol. IV, Madrid: 337-347 Rodríguez Colmenero, A., 1987: Aquae Flaviae. I. Fontes epigráficas, Chaves

Rodríguez Colmenero, A. (coord.), 1996: Lucus Augusti. I. El amañecer de una ciudad, Corunha

RodRÍGUEZ NEILA, Juan Francisco, 1998: "Hispani principes. Algunas reflexiones sobre los grupos dirigentes de la Hispania prerromana", Cuadernos de Arqueologia de la Universidad de Navarra, 6: 99-137 
Rodríguez NeILA, J. F., e NAVARro SAnTANA, F. J., 1998: Los pueblos prerromanos del Norte de Hispania. Una transición cultural como debate histórico, Pamplona Roldén Hervás, José Manuel, 1973: Itineraria Hispana. Fuentes antiguas para el estudio de las vías romanas en la Península Ibérica, Valladolid

RoldÁn HeRvÁs, José Manuel, 1986: "La ocupación romana de la Asturia Augustana y la fundación de Astorga”, in Actas del I Congreso Internacional Astorga romana, Astorga: 37-53

Sagredo SAn Eustáquio, Luís e Ortíz de ZÁrate, Santos Crespo, 1978: Epigrafía romana de la província de Palencia, Valladolid

SALINAS DE FRÍAS, M., 1989: "Sobre las formas de propriedad comunal de la cuenca del Duero en época prerromana”, Veleia, 6: 103-110

SALINAS DE FríAS, M., 1994: "Unidades organizativas indígenas y administración romana en el valle del Duero", in GonzÁlez, Mª Cruz e SANTos, Juan (eds.), Las estructuras sociales indígenas del Norte de la Península Ibérica, Vitória-Gasteiz: 167-179

SALINAS DE FríAs, M., 1994 (1): “Onomástica y sociedad en la epigrafía antigua de las províncias de Salamanca y Avila”, Zephyrus, 47: 287-309

SAlinAs de FríAs, M., 1998: "Los pueblos celtibéricos de la Meseta central”, in Rodríguez Neila, J. F. e Navarro Santana, F. J., Los pueblos prerromanos del Norte de Hispania. Una transición cultural como debate histórico, Pamplona

SANCHEZ MoRENo, Eduardo, 1996: "A propósito de las gentilitates: los grupos familiares del área vetona y su adecuación para la interpretación de la organización social prerromana", Veleia, 13: 115-142

SANCHEZ MORENO, Eduardo, 2000: Vetones: história y arqueología de un pueblo prerromano, Madrid

SAnChez-Palencia, F. Javier (ed.), 2000: Las Médulas (León). Un paisaje cultural en la “Asturia Augustana”, León

Sanchez-Palencia, F. Javier e Fernández-Posse, Ma ${ }^{a}$. Dolores, 1985: La Corona y el Castro de Corporales, I, Madrid

SANTOS, Juan, 1994: "Comunidades indígenas y administración romana en el Norte de la Península Ibérica”, in GonZÁlEZ, Maㅡ Cruz e SANTOS, Juan (eds.), Las estructuras sociales indígenas del Norte de la Península Ibérica, Vitória-Gasteiz: 181-199

SANTOS Yanguas, Juan, 1985: Comunidades indígenas y administración romana en el Noroeste hispánico, Vitória

SANTOS YANGUAS, Juan, 1995: “1985-1994. Un decenio fructífero en la investigación de las estructuras sociales indígenas del área indoeuropea de Hispania”, Veleia, 12: $125-149$

Santos Yanguas, N., 1992: “Ástures y Cantabros: estudio etnogeográfico”, in AlmAgro-Gorbea, M. e Ruíz Zapatero, G., Paleoetnologia de la Península Ibérica (=Complutum, 2-3), Madrid: 417-430

SANTOS Yanguas, Narciso, 2000: "La inscripción de Torrevega (Llanes) y los Orgenomescos en el occidente de la Cantabria antigua”, Veleia, 17: 103-114 
Sanz Mínguez, Carlos, 1998: Los Vacceos: cultura y ritos funerários de un pueblo prerromano del valle medio del Duero. La necrópole de las Ruedas, Padilla del Duero (Valladolid), Salamanca

SAStre Prats, Inés, 1998: Formas de dependencia social en el Noroeste peninsular. Transición del mundo prerromano al romano y época imperial, Ponferrada SASTRE PrATS, Inés, 1999(1): "La formación de los grupos dominantes en las zonas mineras de la Asturia Augustana”, Archivo Español de Arqueologia, 72: 273-279

SASTRE Prats, Inés, 1999(2): "Estructura de explotación social del território en la civitas Zoelarum”, Gérion, 17: 345-359

SASTRE PRATS, Inés, 2001: Las formaciones sociales rurales de la Asturia romana, Madrid SASTRE PRATS, Inés, 2002: Onomástica y relaciones políticas en la epigrafia del conventus Asturum durante el Alto Imperio, Madrid

Sastre Prats, I.; Árbol Moro, M. Ruíz del; Plácido Suárez, D., 1999: "La integración de las comunidades indígenas del noroeste peninsular en el mundo romano: el papel de los pactos de hospitalidad y patronato", in BALBín BEHRMAnN, R. de e Bueno Ramírez, P. (eds.), II Congreso de Arqueologia Peninsular, tomo IV, Arqueologia romana y medieval, Alcalá: 39-50

Sastre Prats, I. e Plácido SuÁrez, D., 1999: “Onomástica y formas de dependencia en el Noroeste peninsular”, in VILlar, F. e Beltrán, F. Pueblos, lenguas y escrituras en la Hispania prerromana (Actas del VII Colóquio de lenguas y Culturas paleohispánicas), Salamanca: 295-305

Serrano Delgado, José Miguel, 1987-1988: "La aportación de la epigrafía para el conocimiento de la amicitia — relación de dependencia en el Alto Imperio", Habis, 18-19: 345-364

Silva, Armando Coelho F. da, 1981-1982: "Novos dados sobre a organização social castreja", Portugália, nova série, 2-3: 83-94

SILVA, Armando Coelho Ferreira da, 1986: A cultura castreja no Noroeste de Portugal, Paços de Ferreira

Smith, J. T., 1997: Roman villas. A study in social structure, Londres/New York

Solana SÁInZ, José María, 1978: Autrigonia romana. Zona de contacto Castilla-Vasconia, Valladolid

Solana SÁinz, José María, 1983: "La expedición de L. Licinio Luculo contra los Vacceos", in Estudios en homenaje a Don Claudio Sanchez Albornoz en sus 90 años (Anejos Cuadernos de História de España): 37-53

Solana SÁinz, José María, 1992: “Los Cántabros: territorio y costumbres”, Hispania Antiqua, 16: 7-54

Solana SÁInz, José María, 1998: “Cántabros. Etnias, território y costumbres”, in Rodríguez Neila, J. F. e Navarro Santana, F. J. (eds.), Los pueblos prerromanos del Norte de Hispania. Una transición cultural como debate hitórico, Pamplona: 217-269

Solana SÁInZ, José María, 1998(1): “Organización y administración del território de los cántabros en el Alto Império”, in HeRnÁNdez Guerra, L. e SAGREdo SAN 
Eustaquio, L. (eds.), El proceso de municipalización en la Hispania romana. Contribuciones a su estudio, Valladolid: 57-80

SouzA, Tude M. De, 1927: Gerez (Notas etnográficas, arqueológicas e históricas), Coimbra

TIR: Tabula Imperii Romani: Hoja K-29: Porto, Madrid, 1991

TIR: Tabula Imperii Romani: Hoja K-30: Madrid, Madrid, 1993

TRANOY, Alain, 1981: La Galice romaine. Recherches sur le nord-ouest de la péninsule ibérique dans l'Antiquité, Paris

Tranoy, Alain, 1986: "Immigration et emigration. Les mouvements de population dans le conventus d'Astorga", in Actas del I Congreso International Astorga romana, Astorga: 123-144

Tranoy, Alain e LE Roux, Patrick, 1989-1990: “As necrópoles de Bracara Augusta.

B. Les inscriptions funéraires", Cadernos de Arqueologia, 6-7: 187-230

VAQUERIZO, Desiderio, 2002: "Espacio y usos funerários en Corduba", in VAQUERIzo,

D. (ed.), Espacios y usos funerários en el Occidente romano, Córdova: 143-200

UnTERMANN, Jürgen, 1965: Elementos de un atlas antroponímico de la Hispania antigua, Madrid

Velaza Frías, Javier, 1989: “Aportaciones a la interpretación del bronce de Montealegre (Valladolid)”, Faventia, 11 (2): 105-120

VILLAR, Francisco, 1995: "El genitivo de plural indoeuropeu prerromano en el epigrafía latina", in Estudios de celtibérico y de toponimia prerromana, Salamanca: 109-119

VILLAR, Francisco, 2000: Indoeuropeus y no Indoeuropeus en la Hispania prerromana, Salamanca 
EST. I

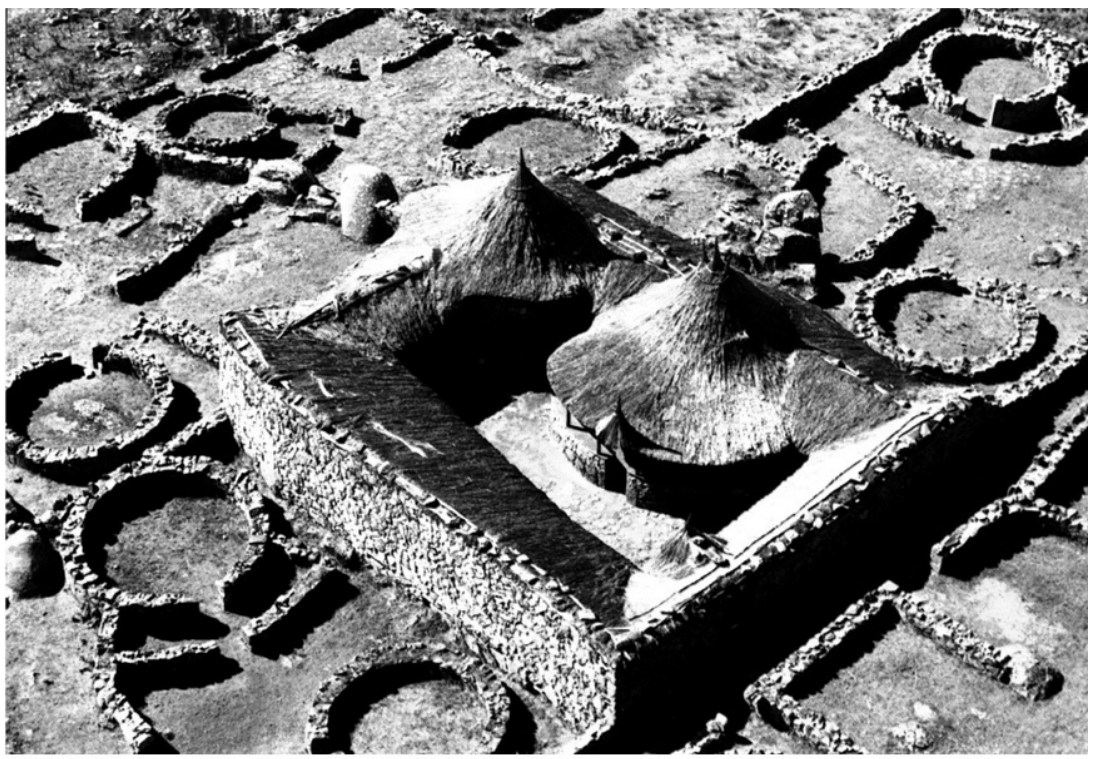

Um dos núcleos familiares da citânia de Sanfins ( Paços de Ferreira, Porto) 
EST. II
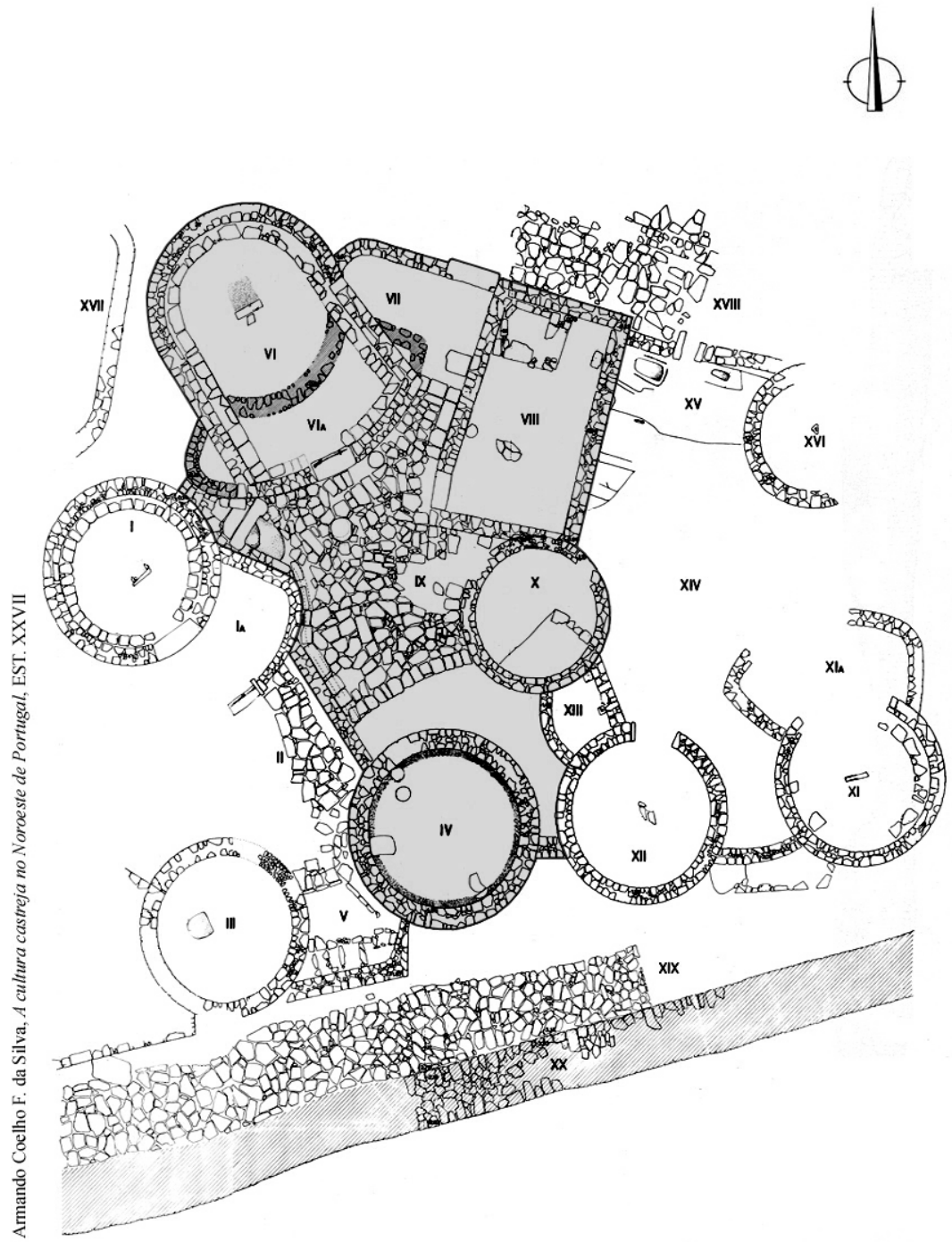

- $2 \mathrm{~m}$

Cividade de Âncora 


\begin{tabular}{|c|c|c|c|}
\hline B 2a & 80 & F 3a & 6000 \\
\hline D $2 a$ & 8 س & $F 3 b$ & $8000 \square$ \\
\hline D 2b & 800 & F 3c & $80 \square$ \\
\hline D 20 & $80 \square$ & $F 3 d$ & $80 \square$ \\
\hline D 2c' & 80 & F 4a & 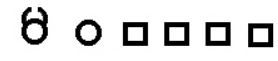 \\
\hline D $3 a$ & $80 \square$ & $\mathrm{F} 4 \mathrm{c}$ & $80 \square$ \\
\hline D 3b & $800 \square$ & $\mathrm{H} 2 \mathrm{a}$ & 800 口 \\
\hline$F 1 b$ & 8000 & $12 a$ & سم 80 \\
\hline & 80 & $12 \mathrm{~b}$ & 80 \\
\hline & هםمس 0 & $12 \mathrm{i}$ & 800 \\
\hline & مس 8 & M 1c & 800 \\
\hline
\end{tabular}

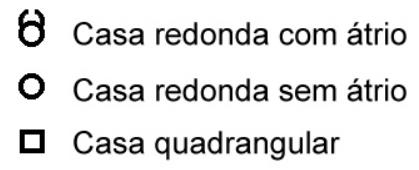




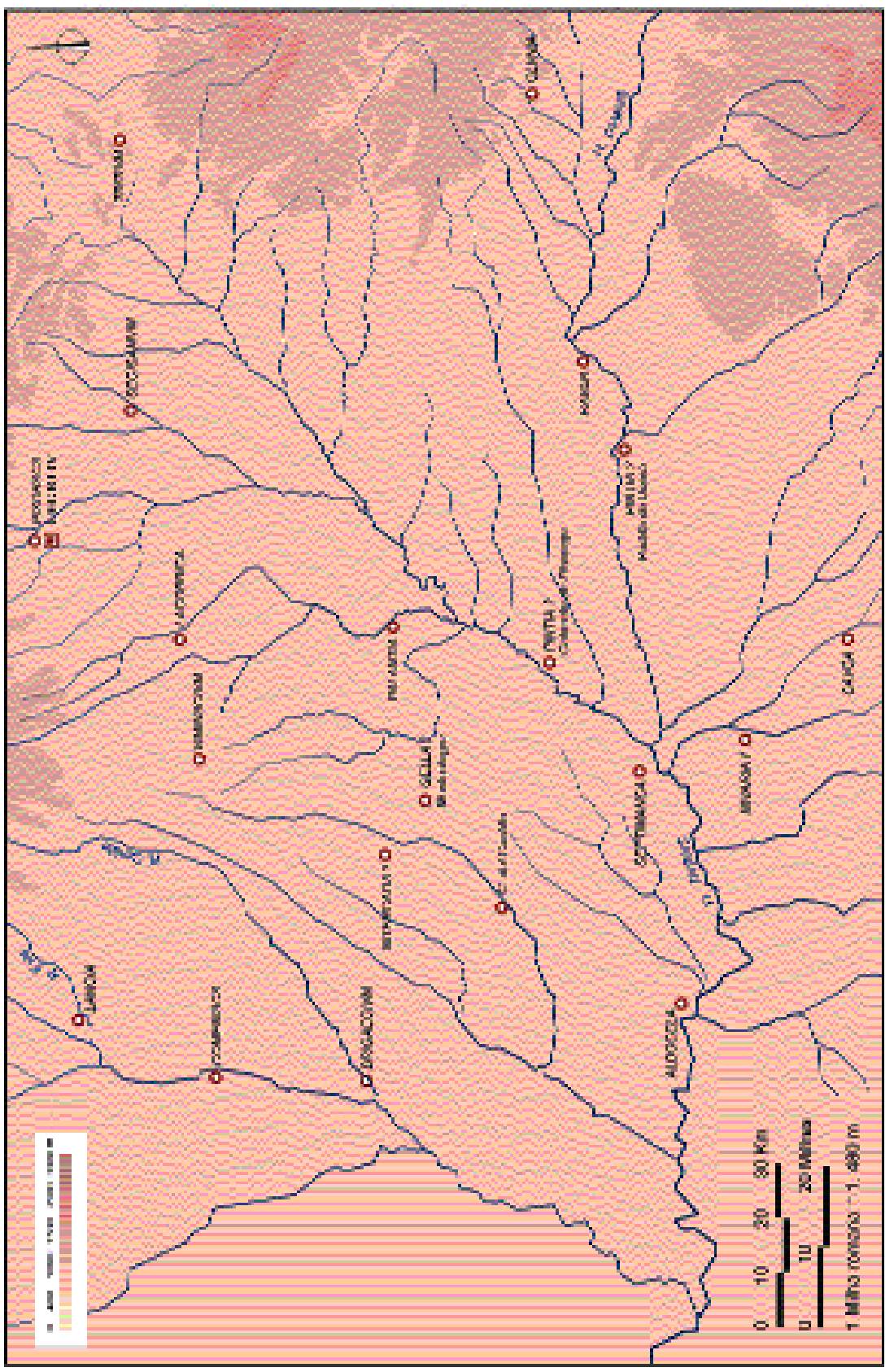


Est. V

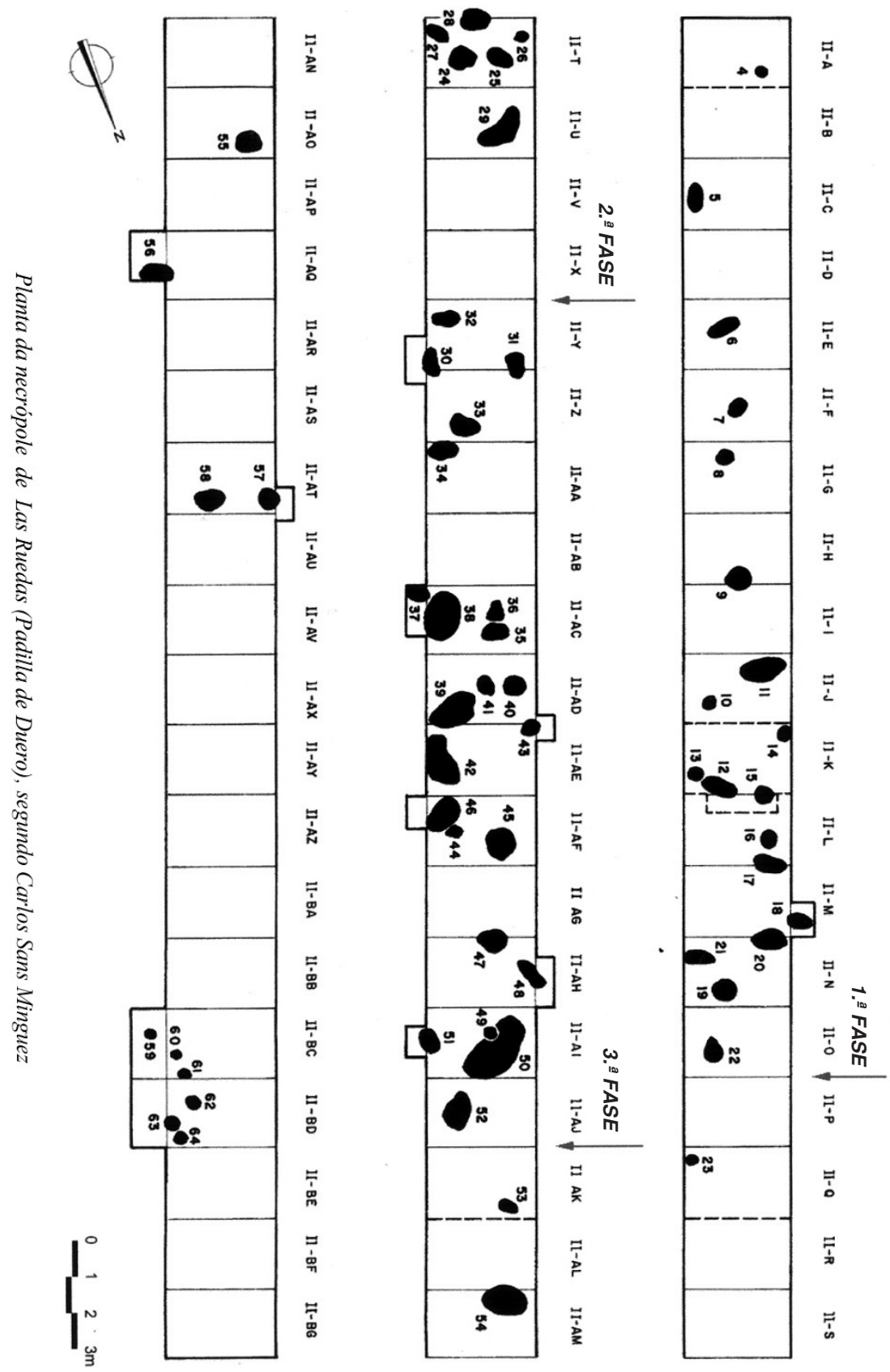




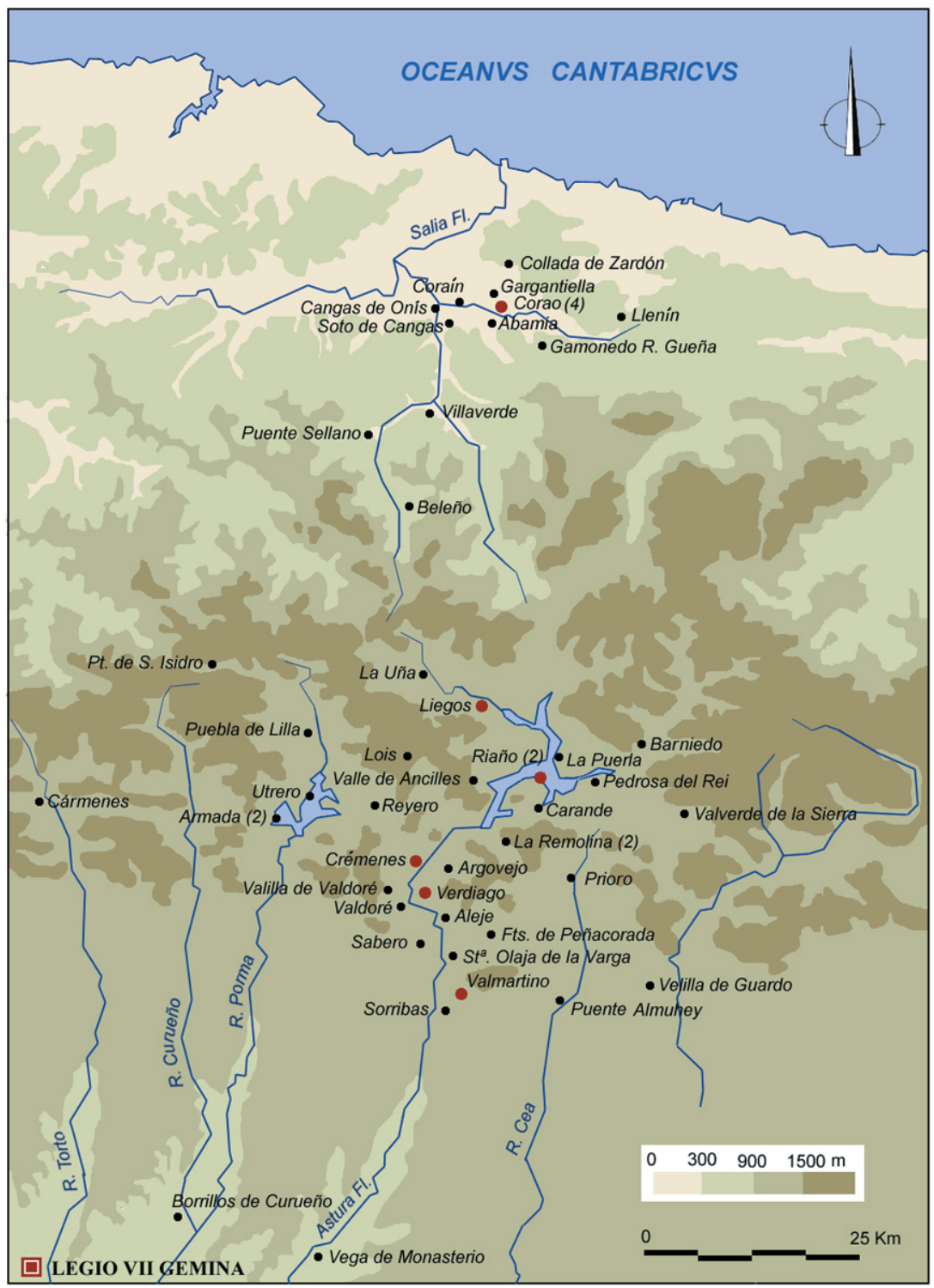

Distribuição da epigrafia vadiniense (segundo J. Liz) DE TIR - HOJA K-30 - Possíveis aglomerados definidos neste nosso artigo 
EsT. VII

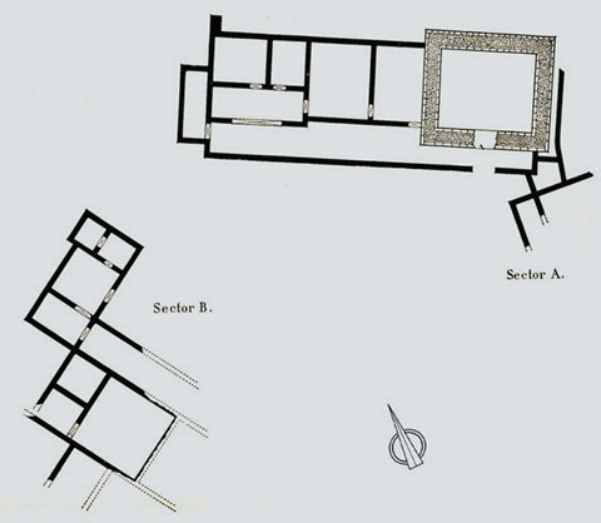

VILLA ROMANA
ot
LAS MVRRIAS DE BELOÑo
Carro. GNóx
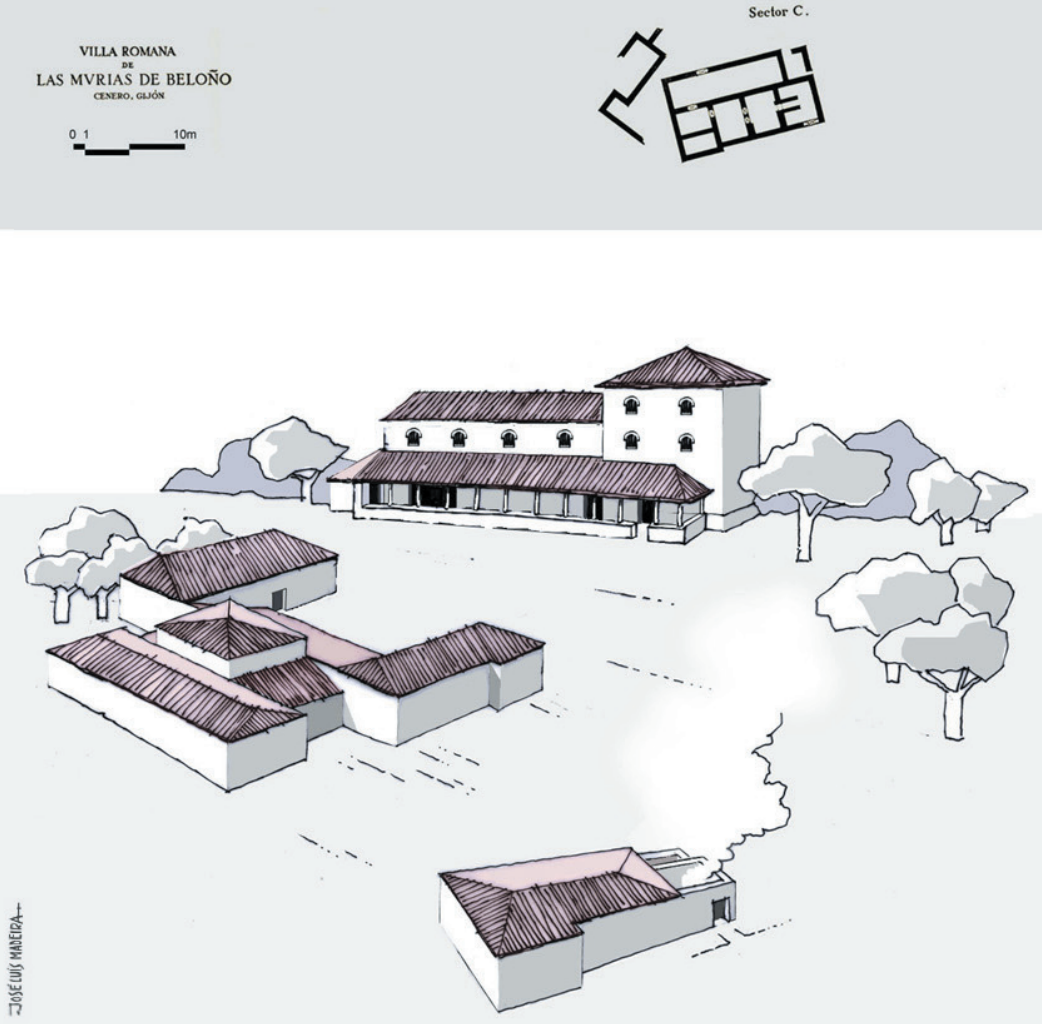